\title{
Zygmunt Zieliński
}

\section{Wykonanie ustaw sejmu pruskiego z dnia 20 V 1874 r. i 22 IV 1875 r. na terenie archidiecezji gnieźnieńskiej}

Prawo Kanoniczne : kwartalnik prawno-historyczny 11/1-2, 153-220

1968

Artykuł został zdigitalizowany i opracowany do udostępnienia w internecie przez Muzeum Historii Polski w ramach prac podejmowanych na rzecz zapewnienia otwartego, powszechnego i trwałego dostępu do polskiego dorobku naukowego i kulturalnego. Artykuł jest umieszczony w kolekcji cyfrowej bazhum.muzhp.pl, gromadzącej zawartość polskich czasopism humanistycznych i społecznych.

Tekst jest udostępniony do wykorzystania w ramach dozwolonego użytku. 


\section{KS. ZYGMUNT ZIELIÑSKI}

\section{WYKONANIE USTAW SEJMU PRUSKIEGO Z DNIA 20 V 1874 R. I 22 IV 1875 R. NA TERENIE ARCHIDIECEZJI GNIEŹNIENSKIEJ.}

Wstęp. Rozdział I. Majątek stolicy arcybiskupiej, kapituły i instytucji diecezjalnych w świetle ustaw z $20 \mathrm{~V} 1874 \mathrm{r}$. i IV $1875 \mathrm{r}$. 1. Stan majątkowy stolicy arcybiskupiej, konsystorza i kapituły meiropolitalnej $\mathrm{w}$ roku 1874. 2. Uposażenie Seminarium Duchownego w Gnieźnie. 3. Treść ustaw z 20 V 1874 r. i 22 IV 1875 r. 4. Ustanowienie zarządu państwowego nad majątkiem kościelnym. 5. Majątek stolicy arcybiskupiej. 6. Majątek kapituły. 7. Majątek Seminarium Duchownego. 8. Instytucje charytatywne. Ro zdzial II. Sytuacja materialna duchowieństwa w świetle tzw. ustawy ,obrocznej" z dnia 22 IV $1875 \mathrm{r}$. 1. Uposażenie parafii przed wybuchem kulturkampfu. 2. Ustawa $z$ dnia 22 IV 1875 r. w odniesieniu do duchowieństwa parafialnego. 3. Straty materialne duchowieństwa. 4. Sprawa Ks. Suszczyńskiego $\mathrm{z}$ Mogilna. $\mathrm{Z}$ a $\mathrm{k}$ oń c zenie.

\section{W s t ęp}

Walka kulturalna, toczona na terenie Prus w latach 1873-1887, znana jest głównie $\mathrm{z}$ tzw. ustaw majowych wydanych $\mathrm{w} 1873 \mathrm{r}$. Ich treść oznaczała daleko idące zmiany w sytuacji prawnej Kościola na terenie Prus, uzależnienie go od wladz rządowych. Prawa te stanowiły też główną oś, wokół której obracała się polityka kościelna rządu pruskiego doby kulturkampfu.

Wykonanie ustawodawstwa majowego natrafiało jednak na zdecydowany opór ze strony hierarchii kościelnej i duchowieństwa parafialnego. Już w 1873 r. wiadomo było, że jedyną szansą dla rządu było użycie siły. Początkowo za środek wystarczający uznal kanclerz Rzeszy Niemieckiej i Prus Bismarck oraz pruski minister wyznań Falk, że wystarczy stosowanie kar administracyjnych i sądowych. Natężenie walki domagało się jednak środków bardziej radykalnych. Pierwszym $z$ nich, podyktowanym zresztą częściowo opróżnieniem 
się w wyniku trwającego kulturkampfu wielu stolic biskupich, była ustawa pruskiego Landtagu z $20 \mathrm{~V} 1874 \mathrm{r}$. o zarządzie opróżnionych biskupstw ${ }^{1}$. Dawała ona władzom możność całkowitego podporządkowania sobie majątku $w$ osieroconych diecezjach, $w$ tym równieź archidiecezji gnieźnieńskiej, której rządca arcybiskup Mieczysław Halka Ledóchowski został 3 II 1874 r. aresztowany i osadzony w więzieniu-w Ostrowie, a następnie 26 IV tegoż roku złożony z urzędu przez Trybunał Królewski dla Spraw Kościelnych.

W rok po wymienionej ustawie Landtag pruski wydał następną, tym razem wymierzoną głównie przeciwko duchowieństwu. Była to ustawa z 22 IV $1875 \mathrm{r}$. zwana pospolicie wówczas „obroczną", gdyż odejmowała ona duchowieństwu świadczenia z kas państwowych ${ }^{2}$.

Obie ustawy mialy raczej charakter represyjny. W wybitnym stopniu odznaczała się nim szczególnie druga. Tym też różniły się one ơ trzeciej ustawy majątkowej, wydanej w okresie kulturkampfu w dniu 20 VI 1875 r., traktującej o zarządzie majątkami parafialnymi. Aczkolwiek władze w wykonaniu tej ustawy kierowały się również przede wszystkim racjami dyktowanymi przez kulturkampf, to jednak założenia jej tak bardzo odbiegały od omawianych tu ustaw, że można ją potraktować zupełnie oddzielnie ${ }^{3}$.

Zajmując się wykonaniem obu branych tu pod uwagę ustaw majątkowych należy przede wszystkim uwzględnić dwa aspekty. Pierwszym będzie siłą rzeczy sama treść ustaw lącznie z dyrektywami wy- ' konawczymi wladz centralnych $i$ wladz terenowych. Drugim zagadnieniem, będącym skutkiem pierwszego jest samo wykonanie ustaw i jego następstwa dla całokształtu spraw diecezjalnych oraz w szczególności dla duchowieństwa parafialnego. Taki podział problematyki pracy, mimo, że jest on $z$ punktu widzenia treści oczywisty, może mieć $w$ rozplanowaniu artykułu tylko względną przydatność. Uchwycenie bowiem przebiegu wydarzeń i odtworzenie sytuacji panującej wówczas w archidiecezji wymaga kolejnego omówienia losów, jakie przechodziły wszystkie instytucje archidiecezjalne. Jest to tym bardziej ważne, że metody postępowania władz $w$ stosunku do poszczególnych instytucji, a nawet osób nie były bynajmniej jednakowe.

$\mathrm{Z}$ prac dotyczących bezpośrednio omawianego tematu należy na

1 Gesetz über die Verwaltung erledigter kath. Bisthümer. Vom 20 $V$ 1874. Gesetzt-Sammlung für die Königlichen Preussischen Staaten. 1874, s. 135. Dalej używać się będzie skrótu: GSS.

2 Gesetzt betreffend die Einstellung der Leistungen aus Staatsmitteln für die römisch-katholischen Bisthümer und Geistlichen. Vom 22 IV 1875. GSS 1875 , s. 338.

$3 \mathrm{Ks}$. Z. Zieliński, Zarząd majątkiem kościelnym w parafiach kat. archidiecezji gnieźnieńskiej w świetle ustawy sejmu pruskiego $z$ dnia 20. VI. 1875 r. Roczniki Teol.-Kan. KUL XIlI (1966) z. 4, s. 119-144. 
pierwszym miejscu wymienić dzieło P. Hinschiusa: „Das preussisches Kirchenrecht im Gebiete des Allgemeinen Landrechts (Berlin — Leipzig 1884). Obok dokładnej treści calokształtu ustawodawstwa kościelnego Prus daje autor doskonały komentarz prawny, tym ważniejszy, że odzwierciedlał on racje, jakimi wówczas kierowały się władze. W mniejszym stopniu przydatne jest dziełko W. Abrahama: „Pruska ustawa kościelno-polityczna z dnia 20 V 1886 r." (Kraków 1886). Autor daje tu krótki przegląd całokształtu ustawodawstwa kulturkampfu z krótkim komentarzem. Pominiemy tu prace dotyczące kulturkampfu w ogóle, czy to na terenie całych Prus, czy też na ziemiach polskich. Kwestie majątkowe, w ogóle gospodarcze tego okresu, są tu z reguły pomijane, lub potraktowane bardzo ogólnikowo. Pozycje częściowo dla niniejszej pracy przydatne to: dzieło $A$. Breitfelda: „Die vermögensrechtliche Ausseinandersetzung zwischen Staat und Kirche in Preussen auf Grundlage der Reichsverfassung (Berlin 1929), oraz dwa artykuły Linneborna: ,Rechtliche Verpflichtungen des preussischen Staatsfiscus für katholische Kirchengemeinden" i „Die Gesamtnachfolge und Verpflichtung des preussischen Staatsfiscus gegenüber katholischen Gemeinden". Prace te dają doskonaly pogląd na zagadnienia prawne związane ze zobowiązaniami państwa wobec parafii w dziedzinie materialnej. Poza tym szczególnie $u$ Breitfelda jest szereg danych liczbowych dotyczących majątku archidiecezji gnieźnieńskiej w XIX w.

Istotnym źródłem dla omawianych $w$ pracy kwestii będą jednak archiwalia przechowywane w Wojewódzkim Archiwum Państwowym w Bydgoszczy (cyt. WAPB), Archiwum miasta Poznania i województwa poznańskiego (cyt. APP), Archiwum Archidiecezji Gnieźnieńskiej (cyt. AAGn) oraz kilka zbiorów akt parafialnych. W archiwach państwowych na specjalną uwagę zasługują zespoły Naczelnego Prezydium w Poznaniu oraz zespoły akt rejencyjnych w Poznaniu i Bydgoszczy (dział: Kirchen - und Schulwesen). Zespół Naczelnego Prezydium obejmuje akta wytworzone w czasie kulturkampfu (w niniejszej pracy okres 1874-1886) zarówno przez władze prezydialne, jak i policyjne i tzw. komisarzy królewskich dla zarządu majątkiem arcybiskupim oraz przez władze centralne, szczególnie ministerstwa wyznań i finansów. W ostatnim przypadku będą to rozporządzenia, wytyczne oraz związana $\mathrm{z}$ tym korespondencja urzędowa. Zespoły rejencyjne zawierają głównie akta wytworzone w toku postępowania urzędowego władz rejencyjnych w stosunku do lạdratów i duchowieństwa parafialnego. Ważną rolę odgrywają tu również brudnopisy sprawozdań rejencyjnych do $\mathrm{Na}$ czelnego Prezydium oraz spora ilość zestawień i etatów majątkowych parafii. Zbiory parafialne zawierają, bardzo niekompletne zresztą, akta dotyczące majątków poszczególnych parafii.

Charakteryzując $w$ ten sposób krótko wykorzystane w pracy archi- 
walia trzeba zaznaczyć, że uczyniono to tu w najbardziej ogólnym zarysie. Szczególowa charakterystyka akt, tutaj dla braku miejsca niemożliwa, wymagałaby specjalnego zajęcia się szeregiem pozycji archiwalnych, co w szczególności odnosiłoby się do wszelkiego typu sprawozdań i tajnych instrukcji.

Materiały z Archiwum Archidiecezjalnego w Gnieźnie dotyczą przede wszystkim spraw kapitulnych; są zresztą ze względu na swą fragmentaryczność mało przydatne, poza jedną teczką dotyczącą dodatków rządowych dla duchowieństwa.

Ważnymi bez wątpienia źródłami były dla pracy wszelkiego rodzaju publikacje urzędowe (Zbiory ustaw, Amtsblatty) władz, dalej, stenogramy z posiedzeń sejmowych, wreszcie miejscowa prasa, z której na największą uwagę zasługuje Kurier Poznański.

Wymienione źródła drukowane i rękopiśmienne stanowią w zasadzie wystarczający materiał do podjęcia tak zakrojonego tematu. Spotyka się jednak w nich luki, stwarzające najwięcej kłopotu w sprawach konkretnych danych liczbowych. Niekiedy można by posłużyć się tu dosyć obfitymi na ten temat informacjami prasowymi. Niestety ścisłość podawanych tam liczb budzi niekiedy pewne zastrzeżenia. Nic więc dziwnego, że niekiedy w pracy uwidaczniać się będzie nieco skąpa ilustracja cyfrowa. Wymagała jednak tego troska o ścisłość przytaczanych liczb.

Istnieją więc w materiale źródłowym pewne braki, ale nie stoją one na przeszkodzie przedstawieniu fragmentu walki kulturnej na terenie archidiecezji gnieźnieńsklej. Nie wykluczają one też moźności scharakteryzowania metod, jakimi władze pruskie posługiwały się w stosunku do Kościoła, a w szczególności do duchowieństwa polskiego. Ta sprawa ma być $w$ pracy szczególnie wyeksponowana, gdyż w gruncie rzeczy stanowi ona najciekawszy moment dziejów kulturkampfu na terenach polskich. Dane liczbowe będą tu więc ilustracją, a zarazem swego rodzaju podsumowaniem skutków, jakie dla archidiecezji gnieźnieńskiej przyniósł kulturkampf.

\section{R O z d z i a I I.}

Majątek stolicy arcybiskupiej, kapituły i instytucji diecezjalnych w świetle ustaw z 20 V 1874 r. i 22 IV 1875 r.

1. Stan majątkowy stolicy arcybiskupiej, konsystorza $i$ kapituly metropolitalnej $w$ roku 1874

Dobra arcybiskupa gnieźnieńskiego zostały całkowicie sekularyzowane w r. 1796. Rozkazem gabinetowym z dnia 28. VII. 1796 r. wyznaczył król pruski arcybiskupom gnieźnieńskim $w$ miejsce zabranych 
dóbr dotację, wynoszącą rocznie 30000 talarów $(90000 \mathrm{mk})$. W bulli „De salute animarum" z 16. VII. 1821 przewidziana była dotacja państwowa dla arcybiskupa, ustalona później w wysokości 12000 talarów (36000 mk). Zmniejszenie dotacji tłumaczy fakt zmniejszenia się pruskiego stanu posiadania na terenach polskich po Kongresie Wiedeńskim. $\mathrm{Z}$ dóbr arcybiskupich stolicy gnieźnieńskiej przy Prusach pozostały tylko klucze: gnieźnieński, żniński, kamieński i część opatowskiego ${ }^{1}$.

Arcybiskup więc otrzymywal od rządu pruskiego rocznie dotację w wysokości $360,00 \mathrm{mk}$. Prócz tego na utrzymanie konsystorza gnieźnieńskiego płacił rząd rocznie $10620 \mathrm{mk}$, na płacę dla pracowników konsystorskich $5363 \mathrm{mk}$, na utrzymanie dla sufragana $2739 \mathrm{mk}$, na sąd synodalny $1800 \mathrm{mk}$, na utrzymanie rezydencji arcybiskupiej 2325 $\mathrm{mk}$, funduszu emerytalnego dla księży $13189 \mathrm{mk}$, wreszcie na dom dla demerytów $7390 \mathrm{mk}^{2}$. Razem więc świadczenia państwowe na rzecz stolicy arcybiskupiej i konsytorza, wliczając $w$ to równiez fundusze emerytalny i na dom dla demerytów, wynosiły rocznie $79936 \mathrm{mk}^{3}$.

W dniu 28 II 1874 r. stan kasy konsystorskiej w Gnieźnie wynosił: w papierach wartościowych $127000 \mathrm{mk}$ i w gotówce $7591 \mathrm{mk}^{4}$. Stan ten nie zmienił się do dnia 25 VI 1874 r., kiedy to agendy majątkowe konsytorza przejął królewski komisarz do zarządu majątkiem arcybiskupim $w$ archidiecezji gnieźnieńskiej ${ }^{5}$.

Kapituła metropolitalna w Gnieźnie otrzymywała łącznie rocznej dotacji państwowej 40,756 mk. Prócz tego trzech kanoników kapituły sw. Jerzego, kolegium penitencjarzy i wikariuszy katedralnych otrzymywali rocznie $z$ kas rządowych łącznie $1202 \mathrm{mk}^{6}$. W kwocie wyplacanej kapitule metropolitalnej mieścily się fundusze przeznaczone na uposażenie poszczególnych kanoników oraz te, które przyjmowała kasa kapitulna ? Nie były to jednak jedyne dochody kapituły. W momencie

1 J. Korytkow ski, Arcybiskupi gnieźnieńscy, Prymasowie Metropolici polscy. Od r. 1000 do 1881, czyli do połączenia arcybiskupstwa gnieźnieńskiego i poznańskiego. Poznań, 1888, t. I, s. 101.

2 APP (Archiwum miasta Poznania i województwa poznańskiego), N. P. XXIV, D I 11, vol. I, k. 83-96 oraz AAGn (Archiwum Archidiecezjalne w Gnieźnie) Akta konsystorskie (dalej: A. kons.) Konsystorza Jeneralnego Arcybiskupiego Gnieźnieńskiego tyczące się rozrachunku kasy konsystorskiej. Gen. 1, vol. I. Zestawienie kasy konsystorskiej $\mathrm{z}$ dnia 28 I $1874 \mathrm{r}$.

${ }^{3}$ Fundusz emerytalny i domu dla demerytów oraz uposażenie arcybiskupie były wspólne dla obu archidiecezji. Wydzielenie części dla jednej $z$ archidiecezji byloby sztuczne $i$ dałoby wynik daleki od przybliżonej nawet dokładności.

4 AAGn, Gen. 1, j. w.

5 APP, N. P. XXIV, D I 11, vol. II, k. 1.

- APP, N. P. XXIV, D I 4, vol. III, k. 4.

7 Tamże, D IIIb 4, vol. II, k. 44. 
rozpoczęcia kulturkampfu posiadała ona szereg kapitałów. Były to: tzw. fundusz dotacyjny (z darowizn) wynoszący $127702 \mathrm{mk}$, fundusz abluicyjny (wykupione ciężary realne) drzewny $-177600 \mathrm{mk}$, fundusz zakrystyjny - $18827 \mathrm{mk}$, fundusz interkalarny - $60995 \mathrm{mk}$, tzw. fundusz memoryjny (fundacje mszalne) - $544078 \mathrm{mk}^{8}$. Biorąc pod uwage rozliczenie $\mathrm{z}$ ostatnich 2 lat kulturkampfu - 1886 i 1887, odsetki od tych kapitałów wynosiły lącznie $37752 \mathrm{mk}^{\ominus}$. Na utrzymanie katedry istniał specjalny fundusz tzw. cathedraticum ustanowione przez rząd pruski w roku 1825. Na fundusz ten składały się części opłat za akty metrykalne, przesyłanych kapitule przez proboszczów. Rocznie wysokość cathedraticum wahala się $w$ granicach $3000 \mathrm{mk}^{10}$.

Pod zarządem kapituły było nadto 7 legatów przeznaczonych na wsparcie dla biednej uczącej się mlodzieży, akcję miłosierdzia i pomoc dla rodzin testatorów. Eącznie suma tych legatów wynosiła $172320 \mathrm{mk}$.

Osobne uposażenie miał sufragan gnieźnieński, prałat kapituły. Należały do niego dochody $z$ probostwa żnińskiego (2751 morgów ziemi $\mathrm{z}$ dochodem rocznym $6476 \mathrm{mk}$ ). Trzeba jednak zaznaczyć, że $\mathrm{z}$ tego opłacał on dwóch pracujących w Żninie księży oraz pokrywał wydatki budowlane kościoła żnińskiego.

\section{Uposażenie Seminarium Duchownego $w$ Gnieźnie}

Źródła dochodowe Seminarium Duchownego były mniej zróżnicowane niż np. w przypadku kapituły. W r. $1874^{11}$ majątek seminaryjny składał się z następujących pozycji:

- w listach zastawnych ziemsikich

- w listach zastawnych za spieniężony inwentarz majątku Braciszewo

- w gotówce

- kapitały abluicyjne

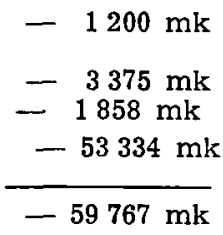

Roczny dochód seminarium był nastẹpujący: 12

8 J. Kory tkow ski, Arcybiskupi... t. I, s. 239.

9 APP, j.W., D I 4, vol. VII, k. $132 \mathrm{nn}$.

10 AAGn, Akta kapitulne (dalej: A. kap.) S 56, Gr II.

11 AAGn, A. kons., Gen. 116, vol II. Akta Konsystorza Jeneralnego, tyczące się poglądu na byłą administrację seminarium w Gnieźnie. Od r. 1874 do r. 1886. Memoriał w sprawie zarządu majątkiem seminaryjskim w Gnieźnie 1874-1886.

12 Tamże. 
- dzierżawa $\mathrm{z}$ majątku Braciszewo

- z ląk

- $\mathrm{z}$ ogrodu

- z kamelarii toruńskiej

- z kapituły metropolitalnej

- procent od kapitałów abluicyjnych

- dotacje państwowe

- fundusz stypendialny gnieżnieńsko-żniński

- $6240 \mathrm{mk}$

- $200 \mathrm{mk}$

- $\quad 270 \mathrm{mk}$

- $1040 \mathrm{mk}$

- $\quad 104 \mathrm{mk}$

$-\quad 2 \overline{6} 66 \mathrm{mk}$

$-11037 \mathrm{mk}^{15}$

- $\quad 750 \mathrm{mk}^{14}$

razem

Tak więc przedstawiał się stan majątkowy stolicy arcybiskupiej, konsystorza, kapituły i Seminarium Duchownego. Z przytoczonego przeglądu cyfr widać jasno, że represje materialne, jakie zastosował w czasie kulturkampfu rząd pruski, miały bez watpienia wiele szans powodzenia. Ten ostatni wniosek narzuca się tym bardziej, gdy się zważy, że właśnie na terenach polskich władze pruskie nie zaniedbały żadnego środka, by zmusić duchowieństwo do uległości.

\section{Treść ustaw $z 20 \quad V \quad 1874 \quad r$. $i \quad 22$ IV $1875 \quad r$.}

Opór, na jaki natrafiło wśród hierarchii kościelnej Prus i duchowieństwa parafialnego wykonanie ustaw majowych 1873 r. zmobilizował władze pruskie do energicznej akcji karnej. Nie przyniosła ona jednak pożądanych skutków - poddania się duchowieństwa nowemu ustawodawstwu. Co więcej, sprawa skomplikowala się dla rządu może najbardziej przez zdecydowany opór biskupów, co w konsekwencji pociągało za sobą zawakowanie szeregu biskupstw. Taki los, jak wiadomo spotkał również archidiecezję gnieźnieńską i poznańską. Ten fakt, jak i potęgujący się opór wobec ustaw majowych wśród duchowieństwa niższego trzeba koniecznie brać pod uwagę przystępując do analizowania omawianych ustaw roku 1874 i 1875. Nie można też stracić z oczu innego faktu, mianowicie, że ustawa z 22 IV 1875 r. została wydana tuż po potępieniu przez Stolicę Apostolską praw majowych i zakazaniu przez nią duchowieństwu stosowania się do nich. Konsekwentnie więc wladze pruskie usiłowały sterroryzować duchowieństwo, uszczupleniem mu środków materialnych, a jeśli zważy się kary, jakje wówczas na

13 APP, j. w., D I 11, vol. I, k. 87-96. Tu dotacja ta wynosila w r. 1874 wymieniona $w$ zestawieniu sumę. W innych latach zauważa się różnicę kilkunastu lub kilkudziesięciu marek. Zob. też AAGn, A. kons. Gen. 88, vol. IV.

14 Suma ta $w$ cytowanym memoriale (zob. przyp. 11) nie jest wymieniona, ale zawierają ją wszystkie zestawienia państwowe i etaty. 
księży nakładano, to $\mathrm{w}$ wielu przypadkach dochodzilo do całkowitego ich zubożenia 15. Zamiar podcięcia podstaw materialnych bytu duchowieństwa był zapewne środkiem dobrze pomyślanym, nie przyniósł jednak i on oczekiwanych owoców.

Ustawa z $20 \mathrm{~V} 1874$ r. ${ }^{16}$ pozbawiała władze kościelne opróżnionych biskupstw calkowicie kompetencji w sprawach administracji majątkowej. W $\S 1$ wspomnianej ustawy stwierdzono, że w każdym biskupstwie katolickim, którego stolica została opróżniona, obojętnie w jaki sposób, czy kanonicznie, czy też skutkiem ustaw państwowych, mają być uprawnienia biskupie, wyjąwszy sprawy zarządu majątkiem kościelnym, wykonywane zgodnie $\mathrm{z}$ przepisami zawartymi w ustawie ${ }^{17}$. Taki stan mial trwać dopóki stolica powtórnie nie zostanie obsadzona. Uprawnienia biskupie $w$ rozumieniu ustawy, to te, które przysługiwały biskupowi jako ordynariuszowi, zarówno $z$ tytułu święceń, jak i juryzdykcji ${ }^{18}$. To sformułowanie wstępne ustawy, szczególnie zastrzeżenie dotyczące zarządu majątkiem, było bez znaczenia praktycznego. Jedno tylko było tu pewne, ze władze państwowe przejmą całkowicie agendy administracyjno-majątkowe diecezji 19 .

Paragrafy 2-4 określały warunki uznania przez państwo biskupa. Prócz przysięgi na wierność państwu miał kandydat na biskupa złożyć naczelnemu prezesowi prowincji oświadczenie o charakterze i zakresie swej działalności biskupiej. Gdyby naczelny prezes wydał orzeczenie o niezdolności biskupa do sprawowania urzẹdu, pozostawało odwolanie się od tej decyzji do Królewskiego Trybunału dla Spraw Duchownych. Paragraf 5 przewidywal złożenie z urzẹdu każdego biskupa, który przeciwstawiłby się wymogom ustawy oraz tych wszystkich, którzy w takim przypadku okazaliby biskupowi posłuszeństwo. W przypadku opróżnienia się stolicy biskupiej na mocy wyroku sądowego, naczelny prezes miał obowiązek wezwać kapitułę do wyboru wikariusza kapitulnego $(\S 6)^{20}$. Wyznaczono na to termin 10-dniowy. Gdyby kapituła nie spełniła nałożonego na nią obowiązku, minister wyznań miał wyznaczyć dla wakującej diecezji komisarza, którego zadaniem byłoby przejęcie zarządu nad całym majątkiem stolicy biskupiej, oraz wyko-

15 W. B us smann, Das Zeitalter Bismarcks. Handbuch der Deutschen Geschichte, Bd III, s. 786. Pius IX w dniu 5 II 1875 ogłosil ustawy Kulturkampfu za nieważne i zagroził ekskomuniką za stosowanie się do nich.

16 GSS 1874, s. 135 .

$17 \mathrm{P}$. H in s chi us, Das preussisches Kirchenrecht im Gebiete des Allgemeinen Landrechts. Berlin-Leipzig, 1884, s. 485, uw. 33 ,

18 Tamże, s. 486, uw. 34.

19 Tamże, s. 486 , uw. 34.

20 GSS 1873, s. 191. Ustawa z 11 V 1873 r., § 21. 
nywanie kontroli nad majątkiem kościelnym, przysługującej biskupowi ordynariuszowi. Zabezpieczenie agend majątkowych wakującej diecezji przez władze prowincjalne miało nastąpić jeszcze przed dokonaniem przez kapitulę wyboru wikariusza kapitulnego ${ }^{21}$. Przy omawianiu tych paragrafów warto zwrócić uwagę na prawna interpretację pojęcia „majątek stolicy biskupiej". Otóż termin ten nie obejmował majątku osobistego biskupa, majątku kapituły i tych instytucji, które nie były bezpośrednio pod administracją biskupa. Paragraf 6 odnosił się też, jak to określały dwa następne paragrafy do tych przypadków, gdzie wikariusz kapitulny ustępował ze swego stanowiska oraz gdy władze w diecezji sprawowała osoba przez ustawę uznana za niezdolną do tego. Paragrafy 3-10 określały bliżej kompetencje komisarzy i warunki ich działalności urzędowej. Komisarz posiadał wszelkie uprawnienia biskupie w zakresie administracji majątkiem stolicy biskupiej ${ }^{22}$. Jego urząd miał jednak charakter prowizoryczny, powierniczy. Zadaniem komisarza było po prostu zabezpieczenie powierzonego sobie majątku, uchronienie go przed stratami, jakie mogły wyniknąć w czasie wakansu stolicy biskupiej. Dlatego też komisarz nie miał prawa podejmowania takich operacji administrowanym majątkiem, które nie byłyby podyktowane aktualną koniecznością, związaną $\mathrm{z}$ ochroną tego majątku. Komisarz był więc, jak gdyby zaangażowanym przez państwo urzędnikiem kościelnym. Na słuszność takiego określenia jego funkcji wskazywałby również fakt, $\dot{z}$ e calkowity koszt administracji majątkiem stolicy biskupiej łącznie $\mathrm{z}$ pensją dla komisarza pokrywany był $\mathrm{z}$ tegoż majątku. Paragraf 9 stwierdzal również, że władza komisarza miała rozciągać się na całą diecezję, oczywiście, tylko $\mathrm{w}$ zakresie spraw administracyjno-majątkowych. Komisarz byl odpowiedzialny za swą działalność tylko przed państwową władzą nadzorczą, w szczególności przed Główną Izbą Obrachunkowa. Paragraf 12 wykluczał całkowicie jakiekolwiek kompetencje kapitul w dziedzinie zarządu majątkiem stolicy biskupiej. Paragraf 19 odnosił postanowienia ustawy również do tych biskupstw, które zostały opróżnione przed jej wydaniem.

Paragrafy 13-18 omawiały sprawe obsadzania stanowisk kościelnych w diecezjach, gdzie urzędował komisarz. Obowiązek obsadzenia wakującego urzędu kościelnego spoczywal na patronie. W przypadku nie dopełnienia obowiązku tego w ciągu jednego roku, prawo obsadzenia urzędu kościelnego przechodziło na gminę kościelną, która miała po prostu dokonać wyboru proboszcza. Sam sposób przepro-

21 P. H in s c hi u s, dz. c., s. 492, uw. 65.

22 Tamże, s. 495, uw. 76.

11 - Prawo Kanoniczne 
wadzenia wyboru określały paragrafy 16 i 17, wyznaczając tu główną rolę landratom $z$.

Sledząc myśl przewodnią omawianej ustawy, można się łatwo zorientować, jaki był jej cel. Było nim w pierwszym rzędzie zastraszenie władz kościelnych i podległego im duchowieństwa. Praktycznie rzecz biorąc każda próba oporu ze strony władz diecezjalnych, czy nawet księży groziła natychmiastowym pozbawieniem ich prawa wykonywania urzędu. Zanosiło się więc na likwidację oficjalnie działającej władzy duchownej $w$ wielu diecezjach. Sytuację pogarszal fakt, że właściwie nie było już nadziei na żadne rokowania episkopatu pruskiego z rządem. O poddaniu się nowej ustawie, co oznaczało właściwie całkowitą kapitulację wobec poczynań rządu w kulturkampfie, nie było jednak mowy. Konsekwentnie więc walka musiała się spotęgować. Owczesny minister wyznań Falk, obejmując w 1872 r. to stanowisko. usłyszal od Bismarcka wskazówkę, że powinien ,usztywnić prawa państwa wobec Kościoła, ale możliwie bez hałasu" ${ }^{24}$. Życzenie Bismarcka było już $w$ świetle ustaw majowych $1873 \mathrm{r}$. nierealne. Możliwości jego wypełnienia zmalały jednak jeszcze bardziej po ukazaniu się ustawy z $20 \mathrm{~V} 1874 \mathrm{r}$. Rząd zresztą dość szybko się przekonał, że ustawa ta poza zaognieniem sytuacji nie przyniesie innych skutków. Praktycznie więc upadła ostatecznie koncepcja zmuszenia kościelnych czynników kierowniczych do podporządkowania się ustawodawstwu kulturkampfu. Pozostawała jeszcze tylko próba pozyskania dla polityki rządu duchowieństwa niższego. Jedynym środkiem, na jaki mógł tu rząd liczyć, była poprawa warunków materialnych księżom, którzy okazaliby posłuszeństwo wobec ustaw, a z drugiej strony represje, również ṇatury materialnej, wobec opornych. Ta myśl leżala niezawodnie u podstaw ustawy z 22 IV 1875 r.

Treść ustawy z 22 IV 1875 r. ${ }^{25}$.

Najbardziej ogólnie rzecz biorąc, ustawa ta znosiła na terenie wszystkich diecezji pruskich świadczenia $z$ kas państwowych na rzecz biskupstw, instytucji kościelnych i duchowieństwa parafialnego. Nie odnosiło się to do duchownych zatrudnionych u specjalnych zakładach kościelnych i państwowych. Do zasobów państwa w pojęciu

${ }^{23}$ Dokładniej sprawę tę omawiała ustawa z 21 V 1874 r.: Gesetz wegen Deklaration und Ergänzung des Gesetzes vom $11 \mathrm{~V} 1873$ über die Vorbildung und Anstellung der Geistlichen. GSS 1874, s. $243 \mathrm{nn}$.

${ }_{24}$ G. Franz, Kulturkampf. Staat und katholische Kirche von der Säkulerisation bis zum Abschluss des preussischen Kulturkampfes. München 1954, s. 331.

25 GSS 1875 , s. $338 \mathrm{nn}$. 
ustawy należały również te fundusze, które znajdowały się pod trwalym zarządem państwowym ${ }^{26}$.

Przywrócenie świadczeń mogło nastąpić jedynie w przypadku, gdy: - zarządzający aktualnie diecezją biskup lub inny jej rządca piśmiennie zobowiązał się do przestrzegania wydanych w kulturkampfie ustaw ${ }^{27}$;

- w archidiecezji gnieźnieńskiej i poznańskiej ustanowiony zostanie, zgodnie z ustawą z dnia $20 \mathrm{~V} 1874 \mathrm{r}$. tymczasowy zarządca lub nowy ordynariusz ${ }^{28}$.

Taka była treść paragrafów 2 i 3 . W przypadku ,gdyby przewidywania w nich zawarte miały się spełnić, ustawa z 22 IV $1875 \mathrm{r}$. byłaby nadal stosowana jedynie $w$ poszczególnych przypadkach, gdzie władze wśród duchowieństwa napotkałyby na opór ( $\$ 5$ ). Z drugiej strony nawet przy zastosowaniu ustawy $w$ stosunku do calej diecezji, nie miała się ona odnosić do tych księży, którzy osobiście okażą posłuszeństwo wobec ustaw kulturkampfu ( $\$ 6$ ). Wobec tych księży władze duchowne nie mogły legalnie stosować kar kościelnych. Ukarany kapłan miał prawo zaskarżyć władze kościelne do naczelnego prezesa i do Trybunału dla Spraw Duchownych ${ }^{29}$ (§ 7). Mógł to nawet uczynić sam naczelny prezes, nawet bez zgody ukaranego księdza.

Przeznaczenie funduszów, jakie skutkiem ustawy z 22 IV pozostaly w rękach państwa miało być ustalone specjalnym rozporządzeniem. Zadecydowano jedynie natychmiast o funduszu dotacyjnym państwa na rzecz duchowieństwa $i$ instytucji kościelnych. Miał on być potraktowany, jako oszczędności państwowe ${ }^{30}$. Jedynie $\mathrm{w}$ przypadku funduszów uposażenia biskupiego mógł minister wyznań wyznaczyć pewną ich część na cele związane z administracją majątkiem stolicy biskupiej ${ }^{31}$.

Egzekucyjne ściąganie przez państwo w drodze administracyjnej podatków i świadczeń wiernych na rzecz instytucji kościelnych nie

26 Tamże, s. 339, \& 1 cyt. ustawy. Określenie „besonderer Fond" oznaczało wszystkie kapitały zabezpieczone $w$ listach zastawnych, lub obligacjach państwowych. również legaty mszalne.

${ }_{27}$ Przede wszystkim miano tu na myśli ustawy majowe z $1873 \mathrm{r}$.

28 AAGn, A. kap., O 29, Gr 4 II. Pismo nacz. prez. Prowincji Poznańskiej do kapituły gnieźnieńskiej z dnia 9 VI 1874 r. w sprawie wyboru wikariusza kapitulnego.

${ }^{29}$ GSS 1873, s. 189. Gesetz über die kirchliche Disziplinargewalt und die Einrichtung des Königlichen Gerichtshofes für kirchliche Angelegenheiten. Vom $12 \mathrm{~V} 1873$. $\S 12 \mathrm{w}$ tym przypadku nie obowiązywał.

30 Mowa tu o tzw. kompetencjach państwowych, czyli sumach placonych Kościołowi przez państwo tytułem wyrównania za sekularyzowane dobra kościelne.

31 GSS 1874 , s. $135 \mathrm{nn}, \S 9$. 
miało być tak dlugo wykonywane, jak długo obowiązywała „ustawa obroczna" 32 .

Paragraf 15 przewidywał sankcje karne $(30 q-3000 \mathrm{mk})$ na księży, którzy uzyskawszy wyjęcie spod ustawy z $22 \mathrm{IV}$, później zmienili swe stanowisko wobec władz państwowych. Prócz kar pieniężnych groziło tego rodzaju osobom sądowne pozbawienie sprawowanego przez nie urzędu.

Ustawa z 22 IV była mocnym uderzeniem, szczególnie w duchowieństwo parafialne. Nie tylko odbierała mu znaczną część dochodów, ale ponadto rozszerzała bardziej jeszcze możliwości stosowania przez władze kar pieniężnych. Pozostawiono księżom tylko dwie drogi. Albo podporządkowanie się ustawowm $i$ w zamian za to utrzymanie a nawet powiększenie swego stanu posiadania, albo też, w przypadku negatywnego stanowiska wobec wladz, groźba pozbawienia środków materialnych. Władze zdecydowane były nawet zapewnić posłusznym sobie księżom opiekę przed postępowaniem dyscyplinarnym władz kościelnych. Nie wymagano też wyraźnych, pisemnych deklaracji (od duchowieństwa niższego) podporządkowania się ustawom kulturkampfu, wystarczalo, że ksiądz czynnie okazał swą uległość wobec władz"ss. Władze jednak formułując $w$ ten sposób treść ustawy mogły liczyć tylko na najgorsze jednostki wśród duchowieństwa. Warunki bowiem stawiane księżom były jawnie równoznaczne z odstępstwem od Kościoła.

Inna rzecz, charakterystyczna dla ustawy z 22 IV, to niejasne ujęcie najważniejszego $\mathrm{w}$ niej momentu. Mamy na myśli określenie „zasoby państwa", rozszerzono je na tzw. „osobne fundusze, będące pod trwałą administracją państwową" ${ }^{4}$. Dopiero wykonanie ustawy wykazało jak wygodną i szeroką furtkę rząd sobie tu otworzył. Przy takim sformułowaniu prawnym nic właściwie nie krępowało inicjatywy władz wyikonawczych. Dla Koscioła miało to, oczywiscie, fatalne skutki.

32 Tamże, § 10. Tu mowa o tzw. repartycjach parafialnych, czyli jednorazowym opodatkowaniu parafian na specjalne inwestycje parafialne.

${ }^{33}$ Odnośny ustęp cyt. ust. brzmi dosłownie: „(D)ie Staatsregierung ist ermächtigt die eingestellten Leistungen einzelnen Empfangsberechtigten gegenüber wieder aufzunehmen, wenn sie durch Handlungen die Absicht an den Tag legen, die Gesetze des Staates zu befolgen". Takim czynem mogła być np. korespondencja $z$ komisarzem, której prowadzenia $z$ reguły księża odmawiali.

$34 \S 1$, ust. 3 cytowanej ustawy. 


\section{Ustanowienie zarządu państwowego nad majatkiem kościelnym}

W dniu 3 II 1874 r. arcybiskup Ledóchowski znalazl się w więzieniu w Ostrowie. Już 26 IV tego samego roku Królewski Trybunał dla Spraw Duchownych w Berlinie złożył go z urzędu ${ }^{35}$. W niecały miesiąc później ukazała się ustawa o zarządzie majątkiem opróżnionych bìskupstw. Obrady nad tą ustawą trwaly w Landtagu już od 23 I 1874 r. ${ }^{36}$. W dniu 23 III 1874 r. kapituła gnieźnieńska i poznańska wystosowały pisma do sejmu pruskiego, opublikowane nawet $w$ prasie ${ }^{37}$, w których wnosily zastrzeżenie odnośnie roli, jaka projekt ustawy wyznaczał kapitułom w przypadku opróżnienia stolicy biskupiej. Kapituły powolały się tu na rozkaz gabinetowy z 23 VIII 1821 r. ${ }^{38}$ i bullę ,De salute animarum" 39. Protest ten podpisali kanonicy: Droszewski, Kraus, Wojciechowski, Korytkowski i biskup sufragan Cybichowski. Kanonik Duliński nie tylko protestu wspomnianego nie podpisał, ale w zdecydowanie wrogiej Polakom Posener Zeitung wypowiedział się za możliwością wyboru wikariusza kapitulnego. Wyraźnie dawal nawet do zrozumienia, że takie wyjście byłoby dla archidiecezji korzystne, tym bardziej, że, jak mu się wydawało, wybór arcybiskupa Ledóchowskiego był nieważny ${ }^{39}$. Kanonik Duliński był przysłowiową czarną owcą w kapitule gnieźnieńskiej. Za podobne zresztą wystąpienia $\mathrm{w}$ późniejszych czasach kulturkampfu został przez Prusaków odznaczony orderem orła czerwonego. Był to jednak, co silnie należy podkreślić, w obu kapitułach jeden jedyny wyjątek. Kapituły Gniezna i Poznania, wystosowując protest do Landtagu nie mogły się spodziewać pozytywnych skutków. Władze jednak znając stanowisko kapituł zastosowały po ukazaniu się ustawy z $20 \mathrm{~V} 1874$ r. z miejsca taktykę silnego nacisku. Ostatni monit naczelnego prezesa Günthera z Poznania, by kapituła obrała wikariusza kapitulnego wysłany był 9 VI $1874 \mathrm{r}$. Znamienne, że $w$ tym samym dniu konsystorz arcybiskupi w Gnieźnie został przejęty przez komisarza do zarządu majątkiem arcybiskupim ${ }^{41}$. Naczelne Prezydium liczyło tu nie-

${ }^{35}$ Kurier Poznański (dalej: Kur. Pozn.) 1874, 88.

36 Stenographische Berichte über die Verhandlungen der beiden Häuser des Landtages. Haus der Abgeordneten. Anlagen. 1873/4, Bd III, s. $1231 \longrightarrow 1237$.

37 Kur. Pozn. 1874, 109.

38 GSS 1821, s. 113.

${ }^{39}$ P. H in schius, dz. cyt., s. $465 \mathrm{nn}$. Tekst bulli „De salute animarum".

${ }_{40}$ W. Klimkie w ic z, Kardynal Ledóchowski na tle swej epoki. 1822-1902. Kraków 1938, t. II, s. 268. Zob. też Kur. Pozn. 1874, 141, 142.

${ }^{41}$ Ksiegga Konferencyjna $i$ Kronika Seminarium Duchownego $w$ Gnieźnie, s. 50 pkt 1 i 2 (A. S. D. Gniezno). Zob. też Kur. Pozn. 1874,129 i 139 . 
zawodnie na to, że moment ten wywrze odpowiednie wrażenie na kapitule. Okazało się jednak, że nawet tak radykalne posunięcie władz nie zdołało zmienić jej stanowiska. Błąd więc, zarówno prawodawców, jak i wykonawców prawa polegał na tym, że byli oni przekonani o istnieniu realnej możliwości wykonania przez wladze kościelne ustaw i zarządzeń kulturkampfu. Nieliczne tylko jednostki wśród duchowieństwa usiłowały się podporządkiwać nowym prawom, ogół zajął zdecydowanie wrogie wobec nich stanowisko.

Przejęcia konsystorza dokonano, jak wiadomo, 9 VI 1874 r. W tym dniu landrat powiatu gnieźnieńskiego Nollau, burmistrz Gniezna Machattias oraz komisarz obwodowy z Kruszwicy Wendlandt zjawili się $\mathrm{u}$ ks. kan. Korytkowskiego, by $z$ jego rąk przejąć wszystkie agendy majątkowe konsystorskie. Sami ci urzędnicy uważali widocznie swą misję za coś niezwykłego, może nawet spodziewali się czynnego oporu, gdyż powodzenie swej akcji starali się zaasekurować odpowiednią obstawą policyjną. Protest ks. Korytkowskiego przeciwko żądaniu wydania kluczy od biur konsystorskich nie powstrzymał urzędników od wypełnienia ich zadania. Dla uprawomocnienia swej czynności Nollau i towarzyszący mu funkcjonariusze spisali protokól, powołując jako świadków rendanta kasy konsystorskiej ks. Nogę, kancelistę i syndyka Klepaczewskiego, pracownika konsystorza.

Tymczasem zawiadowcą majątku konsystorskiego - wyznaczono Wendlandta. Jemu też powierzono kasę konsystorską, depozyty oraz księgi i pieczęcie konsystorza. Przesyłki pieniężne dla konsystorza miał odtąd odbierać osobiście Nollau. Registratorowi ks. Pasikowskiemu nakazał Nollau, by ten na każde wezwanie władz udostępniał im żądane dokumenty. W razie odmowy groził użyciem siły. W praktyce więc akcja z 9 VI położyła kres istnieniu konstystorza gnieźnieńskiego. Co więcej zajęcie ksiąg i pieczęci konsystorskich wychodziło wlaściwie poza kompetencje władz z tytułu ustawy. Na zajęciu konsystorza kończyła się właściwie rola wspomnianej komisji. Okazało się jednak, że rozgraniczenie między poszczególnymi instytucjami kościelnymi nie byto dla władz pruskich zupełnie jasne, gdyż komisja poprosiła również kapitułę o wydanie ksiąg. Zrezygnowano z tego dopiero po przekonaniu się, że kapitula stanowi zupełnie odrębną korporację, ma swoją osobowość prawną i w ogóle nie podlega ustawie z $20 \mathrm{~V} 1874 \mathrm{r}$.

Lepiej powiodło się wspomnianej komisji w Seminarium Duchownym, gdzie agendy administracyjno-majątkowe przejął również komisarz Wendlandt ${ }^{42}$.

Stan tymczasowy, jaki po dniu 9 VI 1874 r. zapanował w zarządzie majątkiem stolicy arcybiskupiej, nie trwał długo. Już 22 VI 1874 r. na-

\footnotetext{
42 Tamże, Księga Konferencyjna...
} 
czelny prezes Prowincji Poznańskiej zamianował komisarzem do zarządu majątkiem archidiecezji gnieźnieńskiej landrata gnieźnieńskiego Nollaua. Urzędowanie w tym charakterze rozpoczął Nollau 25 VI 48 .

Sklad osobowy konsystorza do tego momentu był następujący ${ }^{44}$ :

- ks. Maciej Dorszewski wikariusz generalny in spiritualibus i oficjal generalny

- ks. Walenty Wojciechowski- I radca

- ks. Jan Korytkowski - II radca

- ks. Ignacy Mąke - III radca i asesor

- Teobald Klepaczewski - syndyk i radca sprawiedliwości

Obok członków konsystorza generalnego byli jeszcze urzędnicy zatrudnieni w biurach konstystorskich ${ }^{45}$ :

- ks. Karol Pasikowski

- ks. Szymański

- ks. Stanisław Noga

- asystent Stryjakowski

- ks. Julian Gołaś

- ks. Stanisław Gdeczyk

- Nepomucen Gadomski

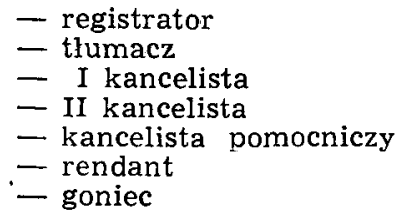

Wszystkim pracownikom biur konsystorskich zaproponowały władze pruskie dalszą pracę na zajmowanych stanowiskach. $Z$ księży nikt tej propozycji nie przyjął. Z świeckich natomiast pozostali wszyscy. Syndyk Klepaczewski uzależnił dalszą pracę od zwiększenia mu uposażenie z 700 talarów rocznej pensji (2100 mk) na 110,0 talarów (3300 $\mathrm{mk}$ ). Zastrzeżenie to zresztą było nawet zbyteczne, gdyż nowe „władze konsystorskie" okazały się dla swych pracowników niezwykle hojne. W niektórych przypadkach hojność ta wyrażała się 100 procentową zwyżką uposażenia ${ }^{40}$.

Nowy skład biur konsystorskich, nie licząc komisarza Nollaua, przedstawial się po 25 VI następująco: ${ }^{47}$

49 APP. j. w. D I 11, vol II, k. 1.

${ }_{44}$ Tamże. Zob. też Elenchus omnium ecclesiarum et universi cleri ersi cleri Archidioecesis Gniesnensis pro Anno Domini 1873, s. 7.

45 Tamże.

46 APP, j. w., k. 1 nn i k. 12.

47 APP, j. W., vol. I, k. 12. 
- kierownik biur i chwilowy zarządca kasy

- jego pomocnik

- kierownik registratury

- syndyk, radca prawny

- pomocnik registratora

- kasztelan (woźny)
- Otto Wendlandt

- Bollmann

- Józef Stryjakowski

- Teobald Klepaczewski

- Józef Bartosiewicz

- Nepomucen Gadomski.

Później skład ten ulegał zmianom. Starano się wprowadzić na stanowiska urzędnicze Niemców. Kancelistą został więc Niemiec Kessler, rendantem Kirsch, nawet woźnego zastąpił Niemiec Silber.

Zanim będzie można przystąpić do naszkicowania 12-letnich dziejów tego jedynego w historii archidiecezji gnieźnieńskiej „\$wieckiego konsystorza", należaloby scharakteryzować sposób i główne cechy jego działania.

Ogólnie zakres działania komisarza do zarządu majątkiem arcybiskupim nakreślała ustawa z $20 \mathrm{~V} 1874 \mathrm{r}$. W praktyce kompetencje komisarza byly z reguly rozszerzone przez rozporządzenia i instrukcje władz nadrzędnych. $Z$ akt przekazanych władzy duchownej $19 \mathrm{~V} 1886 \mathrm{r}$., po likwidacji zarządu komisarycznego wynika, że komisarz zajmował się następującymi sprawami: personaliami pracowników konsystorza, wszystkimi dziedzinami zarządu majątkiem konsystorskim, dalej administracją funduszów podległych konsystorzowi, kwestią etatów majątkowych instytucji kościelnych. Akta komisarskie dotyczyły też takich spraw, jak administracja nieruchomościami kościelnymi archidiecezji, organizacja zarządu majątkowego $w$ archidiecezji, szczególnie w oparciu o ustawe z 20 VI 1875 r. dotyczącą administracji majątków parafialnych ${ }^{48}$. Trzeba by tu jeszcze dodać sprawy seminaryjne, dla których komisarz poświęcał dużo zainteresowania, niestety opuszczając swój posterunek odnośne akta przekazał nie konsystorzowi, ale władzom państwowym ${ }^{49}$.

To schematyczne nakreślenie dziedzin, jakimi zajmował się komisarz nie daje w gruncie rzeczy nawet najbardziej ogólnego obrazu jego działalności. Trzeba więc ją prześledzić na poszczególnych odcinkach życie diecezjalnego. Uprzednio wypadnie tylko jeszcze kilka słów powiedzieć o etapach, jakie przechodził sam urząd komisarza.

Dnia 22 VI 1874 r. komisarzem na archidiecezję gnieźnieńską został landrat Nollau. Urząd komisarza piastował on przez niecałe dwa lata, bo do dnia $3 \mathrm{~V} 1876 \mathrm{r}$. Nollau podobno sam staral się o zwol-

48 APP, j. W., vol. II, k. 177.

49 Nie wszystkie akta zarządu komisarycznego zostały jednak w 1886 r. władzom duchownym wydane. 
nienie $\mathrm{z}$ tego stanowiska. Opinia o nim była wprawdzie lepsza, ni $\dot{z}$ - jego koledze z Poznania Massenbachu, ale faktycznie, delikatniejszy $\mathrm{w}$ niektórych przypadkach sposób postępowania z księżmi u Nollaua, nie łagodził bynajmniej drakońskich praw kulturkampfu. Łagodność ta mogla być zresztą po prostu swoistą metodą, mającą na celu lepsze pozyskanie dla programu państwowego duchowieństwa ${ }^{50}$. Ostatecznie, mimo osobistych starań o dymisję, zmiana na urzędzie komisarskim nie wiązała się bynajmniej $\mathrm{z}$ osobistymi życzeniami Nollaua, lecz raczej $z$ zamierzeniami całkowitej reorganizacji zarządu komisarycznego. Rezygnację z urzędu złożył Nollau 1 IV 1876 r., faktycznie jednak urząd swój sprawowal on jeszcze do końca maja ${ }^{51}$. Nowym komisarzem dla archidiecezji gnieźnieńskiej został Massenbach. Skupił on więc w swym ręku zarząd majątkowy obu archidiecezji ${ }^{52}$. Biura konsystorskie w Gnieźnie zostały zlikwidowane i przeniesione do Poznania. $Z$ pracowników konsystorskich do Poznania przeszło czterech: Klepaczewski, Wendlandt, Stryjakowski i Kirsch ${ }^{5 s}$. Zastępcą Massenbacha na terenie gnieźnieńskim został prokurator gnieźnieński Perkun. Starał się on poprzednio nawet o stanowisko komisarza ${ }^{54}$. Massenbach objął nowy urząd $15 \mathrm{~V} 1876$ r., Perkun cztery dni wcześniej. Nollau miał jednak współdziałać z nowym komisarzem, dopóki całe urządzenie biur konsystorskich nie zostanie przeniesione do Poznania. Sprawy jednak nie układały się tak, jak by sobie tego życzyli Massenbach i Perkun. Swiadczy o tym pismo Massenbacha do naczelnego prezesa $\mathrm{z}$ dniem 8 VI 1876 r. Prosi $w$ nim Massenbach naczelnego prezesa o przynaglenie Nollaua do lepszego współdziałania w likwidacji biur konsystorskich w Gnieźnie i do ostatecznego załatwienia sprawy rozpoczętych remontów w majątku seminaryjnym Braciszewo. $\mathbf{Z}$ korespondencji tej wynika jasno, że Massenbach nie chcial ponosić odpowiedzialności za to wszystko, co w dziedzinie zarządu majątkiem archidiecezjalnym zdziałał Nollau ${ }^{55}$. Gdy chodzi o sprawę majątku Braciszewo, miał chyba rację.

Urzędowanie Massenbacha nie było jednak również długie. Pismem $z$ dnia $29 \times 1877$ roku zostal mianowany komisarzem na obie archidiecezje dotychczasowy zastępca Massenbacha Perkun ${ }^{56}$. Z dotychczasowych pracowników konsystorza, a później administracji komi-

50 Kur. Pozn. 1876, 66.

31 APP, j. w., k. 53.

52 Tamże, k. 39.

53 Tamże, k. 40 oraz Kur. Pozn. 1876, 105.

54 APP, j. w., k. 39-40. Perkun wyraźnie usiłował przekonać naczelnego prezesa, że Nollau nie nadaje się na stanowisko komisarza.

55 Tamże, k. 53.

56 Tamże, k. 79. 
sarycznej, odszedł Klepaczewski. Na jego miejsce zaangażowany został radca ministerialny Gaebel ${ }^{57}$. Taki stan zarządu komisarycznego w obu archidiecezjach przetrwał aż do maja 1886 r., czyli do likwidacji tej instytucji w ogóle.

Kompetencji komisarza nie można omówić generalnie na caly okres kulturkampfu. Były one inne do czasu ukazania się ustawy z dnia 20 VI 1875 r., a inne po jej wydaniu. Na podstawie ustawy majowej $z$ roku 1874 o zarządzie majątkiem wakujących biskupstw komisarz rościł sobie prawo do nadzoru nad majątkiem parafialnym. $\mathrm{Na}$ mocy ustawy o zarządzie majątkiem parafialnym z 20 VI $1875 \mathrm{r}$. administracja tego ostatniego przeszła calkowicie na dozory parafialne. Spory kompetencyjne, jakie się tu wyłoniły nie należą wlaściwie do tego tematu. Warto jednak zaznaczyć, że nie mialy one w pierwszym rzędzie na celu, ze strony kościelnej, wywołania jakiejś akadeınickiej dyskusji prawniczej, lecz realną obronę przed nadużyciem władzy przez komisarzy ${ }^{58}$.

\section{Majatek stolicy arcybiskupiej}

Biorąc pod uwagę etat majątkowy stolicy arcybiskupiej gnieźnieńskiej i poznańskiej $\mathrm{z}$ roku 1874, uposażenie jej $\mathrm{w}$ tym roku wynosiło łącznie $70,586 \mathrm{mk} .{ }^{59} \mathrm{Z}$ tego, jak wiadomo, na utrzymanie arcybiskupa przypadało $36000 \mathrm{mk}$. Los tej sumy rozstrzygną się jednak jeszcze przed ukazaniem się ustawy z 22 IV 1875 r. Uposażenie odjęto arcybiskupowi już $1 \times 1873 \mathrm{r}$. Było to następstwem nieprzejednanej postawy arcybiskupa wobec ustawodawstwa majowego i pierwszym tego rodzaju środkiem represyjnym zastosowanym na terenie archidiecezji w kulturkampfie ${ }^{60}$. Pozostała część uposażenia stolicy arcybiskupiej została zajęta przez państwo w wyniku ustawy z $20 \mathrm{~V}$ $1874 \mathrm{r}$. Wspomniano już, że $\mathrm{z}$ tych funduszów miał być opłacony $\mathrm{m}$. in. komisaryczny zarząd. Przypomnieć też warto, że rola tego ostatniego miala się ograniczyć do czynności niezbędnych dla ochrony powierzonego sobie mienia. Tym bardziej dziwną jest rzecz, że już 16 VII 1874 r. przesłał Nollau do Naczelnego Prezydium nową, opracowaną przez siebie siatkę płac dla swoich pracowników ${ }^{61}$. Jak bardzo róż-

57 Tamże, k. 91.

s8 Sprawa ta jaskrawiej się uwydatnia przy wykonaniu ustawy z 20 VI 1875 r., została też osobno przedstawiona. Zob. przyp. 3 (Wstęp).

${ }^{58}$ APP, j. w., vol. I, k. 87-96.

${ }^{60}$ APP, j. w., D I 4 , vol. VII, k. 59.

61 APP, j. W., D I 11, vol. I, k. 12. 
niła się ona od poprzedniej, nie wykażą cyfry. Syndyk Klepaczewski, mający przed kulturkampfem pensję roczną $2100 \mathrm{mk}$, otrzymywał teraz $3600 \mathrm{mk}^{62}$. Dawny asystent, obecny registrator, zamiast $1020 \mathrm{mk}$ mial pobierać $210,0 \mathrm{mk}^{63}$. Kierownik biur Wenđlandt, prócz swej pensji komisarza obwodowego miał z konsystorza brać rocznie również $2100 \mathrm{mk}$. Warto dla porównania dodać, że ks. Dorszewski, jako oficjał otrzymywal $2400 \mathrm{mk}$ rocznej pensji ${ }^{64}$. W sumie nowy fundusz plac dla pracowników świeckich konsystorza wynosił rocznie $10320 \mathrm{mk}$. Opłacano z tego 6 osób, z tym, że goniec otrzymywał tylko $180 \mathrm{mk}{ }^{65}$. Tymczasem przed przejęciem konsystorza przez komisarza 3 pracownicy biur konsystorskich (świeccy) pobierali lącznie w skali rocznej $3681 \mathrm{mk}$ pensji ${ }^{66}$. Komisarze dla zarządu majątkiem stolicy arcybiskupiej opłacani byli $z$ uposażenia osobistego arcybiskupa. Ich pensja roczna wynosiła początkowo łącznie $9600 \mathrm{mk}$. Z tego Nollau pobierał polowę ${ }^{67}$. Po reorganizacji zarządu komisorycznego 1876 r. Massenbach $\mathrm{i}$ jego zastępca pobierali już pensję roczną $w$ wysokości 6000 mk ${ }^{68}$. Uposażenie Perkuna jako komisarza na obie archidiecezje wynosiło rocznie $7500 \mathrm{mk}$, a od stycznia 1880 r. $8160 \mathrm{mk}^{69}$.

Ten przegląd cyfr ma swoją wymowę. Władze do tej niezbyt wdzięcznej pracy usiłowały sobie kupić ludzi, tym bardziej, że kasy państwowe nie zostaly tą transakcją $w$ najmniejszym stopniu obciążone. Ludzie, których władze, czasowo zresztą pozostawiły $w$ dawnym konsystorzu na stanowiskach, byli potrzebni, ponieważ ich doświadczenie w dziedzinie administracji majątkiem kościelnym gwarantowało uniknięcie pomylek, jakich niechybnie dopuściliby się nie rutynowani nowi pracownicy. Uniknięto więc po prostu komplikacji. Takie właśnie motywy zarówno niezwykłej hojności pruskiej, jak i niechęci do natychmiastowych zmian w skladzie komisarycznego zarządu wynikają jasno $\mathrm{z}$ korespondencji, jaką Nollau prowadził $\mathrm{z}$ naczelnym prezesem ${ }^{70}$. $\mathrm{Z}$ chwilą jednak, gdy biurokracja pruska opanowała dostatecznie nową dla siebie dziedzinę urzędowania, zaczęto stopniowo usuwać pracowników Polaków, by lukratywnymi stanowiskami obdarzyć Niemców. Do jakiego stopnia zbiurokratyzowano dawny konsystorz, niech świadczą o tym dwie porównane ze sobą liczby.

62 APP, j. w., vol. II, k. 1.

63 Tamże.

64 Tamże, vol. I, k. 12.

${ }_{65}$ APP, j. $w$.

${ }^{86}$ APP, j. w., vol. II, k. 1.

67 Tamże, k. 96 i 59.

68 Tamże, k. 35 nn.

Tamże, k. 141.

70 APP, j. W., vol. I, k. 12-47. 
W roku 1874, jeszcze przed przejęciem przez komisarza biur konsystorskich, roczny fundusz na potrzeby biurowe wynosił zaledwie 488 $m^{71}$. Nieco później, bo we wspomnianym już sprawozdaniu Nollaua do naczelnego prezesa, etat kasy konsystorskiej przewidywal już 2 pozycje funduszu administracyjnego:

- na zarząd kasy - $3000 \mathrm{mk}$

- na potrzeby biurowe - $200 \mathrm{mk}$.

Etat organizacyjny komisarycznego zarządu (dawny konsystorz), ustalony na podstawie sprawozdania Nollaua $\mathrm{z}$ dnia 16 VII 1874 r. przewidywal więc łącznie uposażenie pracowników i wydatki biurowe w wysokości $13920 \mathrm{mk}$. Na wydatki nadzwyczajne przewidziano w nim ponadto $290 \mathrm{mk}$. Poza tymi pozycjami widniały $\mathrm{w}$ etacie jeszcze następujące:

- pensje dla profesorów Seminarium duchownego - $3264 \mathrm{mk}$

- fundusz dla emerytowanych pracowników konsystorza - $2380 \mathrm{mk}$.

Eącznie więc etat obejmował sumę rozchodową $19855 \mathrm{mk}$.

Dochody przeznaczone na pokrycie tych wydatków sprowadzały się do dwóch tylko pozycji dawnego etatu stolicy arcybiskupiej. Były nimi dotacja na Seminarium Duchowne, wynoszące w r. $1874-8046$ $\mathrm{mk}$, oraz dotacje na konsystorz, obejmujące w tymże roku sumę $14373 \mathrm{mk}$. Ogółem $\mathrm{z}$ uposażenia rządowego stolicy arcybiskupiej (70585 mk) wypłacało państwo po ustanowieniu zarządu komisorycznego $27702 \mathrm{mk}^{73}$. Taką też kwotę zaprojektował Nollau w piśmie do Naczelnego Prezydium z lipca 1874 r. ${ }^{74}$. Projekt ten, zresztą bardzo dla władz ,oszczędny" zyskał zatwierdzenie naczelnego prezesa $14 \mathrm{X}$ 1874 r. ${ }^{75}$. Etat organizacyjny na rok 1875 przewidywał na siły pracownicze obu zarządów komisorycznych w Gnieźnie i w Poznaniu dodatkową sumę $14460 \mathrm{mk}^{76}$. O dalsze $900 \mathrm{mk}$ wzrósł budżet obu archidiecezji w r. 1884, gdy płacone dawniej diecezji chełmińskiej uposażenie oficjała pomorskiego przeniesiono na archidiecezję gnieźnieńską ${ }^{77}$. Pieniądze te zostały zużytkowane na opłacenie zwiększonej liczby personelu komisarycznego zarządu. W roku 1875 etat organiza-

71 Tamże, k. 1 nn.

72 Tramże, k. $12 \mathrm{nn}$.

73 Tamże, k. 96.

74 Tamże.

75 APP, j. w., D I 4, vol. VII, k. $66 \mathrm{nn}$.

76 A. B reitfeld, Die vermögensrechtliche Auseinandersetzung zwischen Kirche und Staat in Preussen auf Grundlage der Reichsverfassung. Berlin 1929, s. 186.

77 Tamże. 
cyjny dla archidiecezji gnieźnieńskiej wzrósł $\mathrm{w}$ stosunku do poprzedniego roku o $5166 \mathrm{mk}$ i wynosił $32862 \mathrm{mk}$. Były tu wliczone również pensje dla członków konsystorza, księży kanoników Dorszewskiego, Korytkowskiego i Wojciechowskiego $(3150 \mathrm{mk})^{78}$. Osobny etat seminaryjny przewidywał jedynie pensje dla profesorów $w$ łącznej wysokości $4056 \mathrm{mk}^{79}$. Do ukazania się ustawy z 22 IV $1875 \mathrm{r}$. nie miały władze formalnie prawa wstrzymać pensji ani profesorom seminaryjnym, ani członkom konsystorza, mimo, że ten został praktycznie rzecz biorąc zlikwidowany. Gorzej powiodło się księżom pracownikom konsystorza. Skoro tylko odmówili oni wspólpracy z komisarzem, zostali pozbawieni pensji, wynoszących lącznie $4395 \mathrm{mk}$ rocznie.

Etat organizacyjny zarządu komisarycznego zmienił się jeszcze raz $w$ roku 1876. Po ustawie z 22 IV 1875 r. cofnięto bowiem pensje wspomnianym już członkom konsystorza ${ }^{80}$. Jest zresztą rzeczą wątpliwą czy księża ci od chwili likwidacji konsystorza pensję swą pobierali, przyjmując ją bowiem z rąk komisarza, tym samym uznaliby w pewnym sensie jego kompetencje, przed czym ogół księży strzegł się bardzo starannie. Jeśli więc uwzględni się wspomnianą poprzednio poprawkę etatu w $1884 \mathrm{r}$. to można przyjąć, że do $\mathrm{r}$. 1886 pozostawal on w takich granicach budżetowych, jakie nakreślono po ustawie z 22 IV.

Dla pełnego obrazu stosunków, jakie od $1874 \mathrm{r}$. zapanowały $\mathrm{w}$ archidiecezji gnieźnieńskiej należy jeszcze przedstawić losy tych dotacji, jakie konsystorz otrzymywał od państwa na utrzymanie instytucji diecezjalnych oraz przedstawić gospodarkę funduszami, będącymi pod nadzorem konsystorza, a przejętymi przez komisarza. Pomijając bezpośrednią dotację państwową na rzecz Seminarium Duchownego, o której będzie mowa przy majątku seminaryjnym, trzeba zwrócić uwagę na dwie jeszcze kwoty płacone przez państwo na obie archidiecezje wspólnie. Były to:

- fundusz emerytalny - $\quad 13189 \mathrm{mk}$

_- funđusz zakładu demerytów - $7390 \mathrm{mk}^{\mathrm{R}}$.

Fundusz dla zakładu demerytów nie zostal wstrzymany ustawą z $r$. 1874. Trudno właściwie powiedzieć dlaczego tak się stało. Zakład

\footnotetext{
78 APP, j. w., D I 11, vol. I, k. 47.

79 Tamże, k. 52.

80 APP, j. w., D I 14, vol. II, k. 236.

81 APP, j. w., D I 11, vol. 1, k. 90-96.
} 
demerytów został bowiem zamknięty na mocy ustawy z 12 V $1873^{82}$. Te same wątpliwości nasuwa pozostawienie po roku $1874 \mathrm{w}$ etacie arcybiskupstwa gnieźnieńskiego i poznańskiego wspomnianej wyżej dotacji. Zastrzeżono tam tylko, że płatność tego funduszu obowiązywać będzie do odwołania. Był to zresztą gest biurokratyczny bez praktycznego znaczenia, gdyż od r. 1874 wszystkie fundusze stolicy arcybiskupiej były już pod administracją komisaryczną. Formalnie dotację dla zakładu demerytów i fundusz emerytalny cofnięto $w$ wyniku ustawy z 22 IV 1875 r. Odwolania księży emerytów od tej decyzji, drukowane nawet $w$ prasie, nie robiły na naczelnym prezesie najmniejszego wrażenia. Taki stan rzeczy pozostał też aż do r. $1886{ }^{83}$.

Zatrzymane zarządzeniem $\mathrm{z}$ dnia 7 VII 1874 r. fundusze należące do etatu stolicy arcybiskupiej skierowano do głównej kasy państwowej ${ }^{84}$, gdzie zaksięgowano je pod tytułem „oszczędności” ${ }^{85}$. Tak samo potraktowano w roku 1875 wspomniane wyżej dwa fundusze: emerytalny i uposażenie zakładu demerytów. Sytuację administracyjno-finansową $w$ archidiecezji gnieźnieńskiej najlepiej obrazuje sprawozdanie komisarza Perkuna przesłane naczelnemu prezesowi w Poznaniu w 1885 r. Od maja 1875 r. do marca 1885 r. zatrzymano:

- z funduszu stolicy arcybiskupiej lącznie

$-292562 \mathrm{mk}$

- z funduszu demerytalnego

- $72150 \mathrm{mk}$

- $\mathrm{z}$ funduszu emerytalnego

$-25421 \mathrm{mk}^{86}$.

Komisarz dla zarządu majątkiem archidiecezji gnieźnieńskiej przejął w roku 1875 również kapitały będące własnością archidiecezji. Obejmowały one następujące pozycje:

- w książeczkach oszczędnościowych

- w dokumentach hypotecznych

$-214817 \mathrm{mk}$

- w polisach ubezp. na życie

- $259594 \mathrm{mk}$

- $21600 \mathrm{mk}^{87}$.

Inny obraz przejętego przez komisarza majątku archidiecezjalnego daje roczny bilans sporządzony przez zarząd komisoryczny w $1875 \mathrm{r}$.

${ }^{82}$ GSS 1873 , s. 198 , nn.

83 Kur. Pozn. 1875, 150.

$84 \mathrm{APP}, \mathrm{j} . \mathrm{w}$.

85 APP, j. W. D IIIb 4, vol. II, k. 45. We wszystkich zestawieniach kasowych używano określenia „Ersparnisse”.

86 Tamże, vol. III, k. 239. Cyfry te odnoszą się tylko do archidiecezji gnieźnieńskiej.

${ }^{87}$ APP, j. W., D I 27, k. 3. 
Dochód ogólny wynosił

$-219599 \mathrm{mk}$

Rozchód ogólny

Pozostawało

$-218717 \mathrm{mk}$

- $\quad 881 \mathrm{mk}^{88}$.

$\mathrm{Z}$ kolei należy zająć się tzw. funduszem dodatkowym ${ }^{89}$. Ze sprawozdań komisarza za lata 1875-1880 wynika, że zakres tego funduszu obejmował kapitały lub zabezpieczone w jakikolwiek sposób fundacje budowlane, przeznaczone na budowę kościołów lub plebanii ${ }^{90}$. Komisarz przejął administrację tych funduszów, ponieważ przed ustawą z $20 \mathrm{~V}$ były one administrowane przez kasę konsystorską. Przeznaczenie jednak narastających odsetków od lokowanych kapitałów było nawet dla komisarza Nollaua trudną do rozwikłania zagadką. Jedno było tu pewne i to Nollau dostrzegał, ze mianowicie jest to masa majątkowa administracyjnie i dyspozycyjnie niezależna od kasy konsystorskiej. Dlatego też kapitały te były przez komisarza administrowane zupełnie oddzielnie. Stan ich w roku 1875 był już omówiony ${ }^{21}$. W r. 1879 komisarz Perkun donosił ministrowi wyznań, że pod zarządem komisarycznym znajduje się 25 fundacji przeznaczonych na obie archidiecezje. Ich łączny dochód wynosił rocznie $19157 \mathrm{mk}$, z czego na koszty administracyjne potrącono $913 \mathrm{mk}^{92}$. Przeznaczenie tego dochodu było jednak dla komisarza sprawą kłopotliwą. Trzeba było bowiem $\mathrm{z}$ jednej strony stosować się do woli fundatorów, $\mathrm{z}$ drugiej do ustaw z dnia $20 \mathrm{~V} 1874$ r. i 2.2 IV 1875 r. W korespondencji komisarza $z$ naczelnym prezesem, dotyczącej tej sprawy, można dostrzec jakąś obawę przed przekroczeniem obowiązujących przepisów prawnych. Widać to szczególnie w piśmie Nollaua, w którym ten prosi naczelnego prezesa o zadecydowanie o losie „funduszu dodatkowego". Otrzymał on wówczas nakaz, by zgodnie $\mathrm{z}$ przeznaczeniem tych funduszów, skierować je do kas odpowiednich dozorów parafialnych ${ }^{\mathbf{9}}$. Była to zresztą wskazówka najbardziej słuszna, chociaż Nollau, gdyby zapoznał się z ustawą z 20 VI 1875 r., mógłby łatwo do takiego wniosku sam dojśc. Ustawa ta bowiem cały majątek, a więc i fundacje, przeznaczone na cele parafialne, poddawała dozorom. W marcu $1877 \mathrm{r}$. komisarz Perkun donosił jednak naczelnemu prezesowi, że wiele $z$ tzw.

88 Tamże, k. 7.

s9 Określenie „Nebenfonds" zachodzi we wszystkich źródłach niemieckiego pochodzenia. Było ono wieloznaczne i dlatego stosowane do różnych funduszy.

90 APP, j. w., D I 15, k. 1-361 (Kopie etatów).

91 Zob. s. 45.

92 APP, j. W., D I 14, vol. II, k. 87-92.

93 Tamże, k. 15, 16 i 47. 
funduszów dodatkowych nie mogło być odprowadzonych do kas parafialnych, gdyż organizowanie się nowych dozorów postępowało opieszale. Niewątpliwie była $w$ tym część prawdy, ale poza tym Perkun chyba $w$ ten właśnie sposób chciał zwrócić uwage na nieudolność postępowania Nollaua, kiedy ten był komisarzem, w stosunku do dozorów. Nie można zapomnieć, że wlaśnie Perkunowi zależało najbardziej na objęciu $w$ zarząd komisaryczny agend majątkowych obu archidiecezji. Inna jeszcze rzecz, ze komisarze niechętnie wypuszczali $\mathrm{z}$ rąk zajęty przez nich $\mathrm{i}$ administrowany bezpośrednio majątek kościelny. $\mathrm{Z}$ dochodu od skapitalizowanego tzw. funduszu dodatkowego nie wszystko było odprowadzane do kas parafialnych nawet $w$ roku 1879, kiedy przecież dozory byly już na ogół ukonstytuowane. Trudno jednak stwierdzić dlaczego i w jakich konkretnych przypadkach fundusze te zatrzymano.

W ogóle działalność komisarza $w$ dziedzinie administracji majątkiem kościelnym miała zupełnie specyficzny charakter. Nie posiadała ona $w$ zasadzie znamion procedury urzędów państwowych, nie miała też siłą rzeczy cech urzędu kościelnego. Charakter władzy komisarza oddaje najlepiej niemieckie określenie „kommissarische Verwaltung”zarząd komisaryczny i ono jednak nie usuwa dwuznaczności, jaka kryła się w tym sztucznym tworze okresu kulturkampfu. Najdobitniej dwuznaczność ta wychodzi jednak w konkretnym działaniu komisarza ${ }^{94}$.

\section{Majatek kapituly}

Ustawa z 20 V 1874 r. nie dotyczyła właściwie kapituły w ogóle. Ingerencja władz $w$ sprawy majątkowe kapituly polegała więc $w$ czasie kulturkampfu jedynie na rewizjach kasy kapitulnej. Miały one jednak miejsce dopiero od r. $1876^{95}$. Taki był stan prawny. Błędem jednak byłoby przypuszczać, że odpowiadał mu stan faktyczny. Według ustawy z $20 \mathrm{~V} 1874 \mathrm{r}$. kapituła miała odegrać ważną rolę w programie rządowym, miała bowiem wybrać wikariusza kapitulnego i niejako usankcjonować stan wytworzony nowym ustawodawstwem ${ }^{96}$. Wladze jednak przewidywały opór ze strony kapituły. Na wszelki

$94 \mathrm{Na}$ tym tle wyrastały też w znacznej mierze konflikty kompetencyjne, szczególnie między komisarzem i dozorami parafialnymi. Te ostatnie, jak również ogół duchowieństwa widziały w komisarzu tylko zarządce majątkiem arcybiskupim i konsystorskim.

${ }_{95}$ GSS, 1876 ,s. 149 nn. oraz AAGn, O 30, Gr II, nr 227 (1874).

${ }^{96}$ GSS 1874 , s. 135 nn., § 6. 
wypadek zabezpieczyły się one wcześniejszym rozporządzeniem ministra wyznań Falka wydanym w dniu 12 VI 1873 r. ${ }^{98}$ Znosiło ono przyjętą od 39 lat praktykę, polegającą na tym, że rząd wszystkie dotacje dla kapituły wpłacal do kasy kapitulnej i ona dopiero rozprowadzała je według przeznaczenia. Na mocy nowego rozporządzenia każdy $\mathrm{z}$ kanoników mial osobiście $\mathrm{z}$ kasy rejencyjnej odbierać swe uposażenie. O tej decyzji naczelny prezes Prowincji Poznańskiej powiadomił kapitułę ${ }^{99}$. Cel tego posunięcia nie budzi dziś żadnych wątpliwości, inaczej było jednak wówczas $w$ czasje, kiedy prawa majowe wchodziły dopiero $\mathrm{w}$ życie i trudno było przewidzieć metode postępowania Prusaków. Tym właśnie można wytłumaczyć odpowiedź obu kapituł, gnieźnieńskiej i poznańskiej, skierowaną do naczelnego prezesa Günthera w dniu 18 VI 1873 r. W imieniu kapituły gnieźnieńskiej podpisał ją kanonik Zienkiewicz ${ }^{100}$. Kapituła wprawdzie zaprotestowała przeciwko zarządzeniu Falka, ale oświadczyła, że dochody, nawet tym sposobem placone, nadal będzie pobieraé. Korespondencja $w$ tej sprawie trwała aż do $r$. 1875, kiedy to dochody kapituły zostały wstrzymane „ustawą obroczną" ${ }^{101 .}$

Drugą sprawą, którą władze też rozstrzygnęły na swoją korzyść, to sprawa uposażenia wolnej od 20 I $1874 \mathrm{r}$. prebendy proboszczowskiej po zmarłym właśnie kan. Zienkiewiczu ${ }^{102}$. Kapituła zwróciła się do naczelnego prezesa $\mathrm{z}$ prośbą o wyplacenie dochodów wakującej prebendy, zgodnie $z$ rozporządzeniem wykonawczym bulli „De salute animarum", wydanym 25 I $1830 \mathrm{r}$. przez biskupa Józefa Hohenzollerna. Wedlug tego rozporządzenia połowa dochodu wakujących prebend kanonickich przeznaczona była na fundusz zakrystyjny katedry, a połowa na powiększenie funduszu dystrybucyjnego kapituły ${ }^{103}$. W roku 1875, już po ukazaniu się ustawy z 22 IV, kapituła korespondowała $w$ tej sprawie $z$ Falkiem ${ }^{104}$. W zasadzie nawet ,ustawa obroczna" dozwalała na wypłacenie polowy dochodu prebendy, przeznaczonej na fundusz zakrystyjny. Nic jednak nie wskazuje na to, by tę część kapitule wypłacono.

Ustawa z 22 IV 1875 r. dotyczyła kapituły w całej rozciągłości. Była jednak w stosunku do niej inaczej wykonywana niż w stosunku do

97 APP, i. w., D I 4, vol. VII, k. 8.

${ }^{98}$ AAGn, A. kap. O 29, Gr 4 II, nr 354. Kur. Pozn. 1873, 140.

99 APP, j. W., k. 33.

100 AAGn, j. W. nr 321 i 333 (1874).

101 Tamże, nr 322 (1874).

102 APP, j. w., k. 31 .

103 AAGn, O 30, Gr 4 II, nr 385 (1875).

104 P. Hins chius, dz. c., s. 477. Tekst bulli "De salute animarum" (XLII).

12 - Prawo Kanoniczne 
innych osób prawnych kościelnych. Los dotacji państwowych dla kapituły z tytułu sekularyzowanych dóbr kapitulnych był podobny co w przypadku stolicy arcybiskupiej. Bulla cyrkumskrypcyjna domagała się zahypotekowania dotacji płaconych przez państwo na lasach państwowych jako na najpewniejszym przedmiocie lokacyjnym ${ }^{105}$. Nie uczyniono tego jednak, a do hypoteki wciągnięte zostały tylko kanonie, wówczas zwane kuriami kanonickimi, wraz $z$ bezpośrednio do nich należącą własnością ${ }^{106}$. Zahypotekowanie ciężarów płatniczych, ciążących na państwie byłoby rzeczą bardzo ważna, gdyż należność ta wówczas przysługiwałaby kapitule z tytułu prawa prywatnego i musiałaby być płacona nawet po ukazaniu się ustawy z 22 IV. ${ }^{107} \mathrm{Na}$ podstawie prawa prywatnego przysługiwało kapitule np. odszkodowanie płacone jej przez kamelarię toruńską w wysokości $2256 \mathrm{mk}$ rocznie. W czerwcu 1875 r. kamelaria, mylnie stosując ustawę kwietniową, zawiadomiła kapitułę, że procenty od posiadanego kapitału wpłacać będzie do kasy komisarycznego zarządu archidiecezji 108. Już jednak po 10 dniach komisarz nakazał sumę tę przekazać do kasy kapitulnej ${ }^{109}$.

Gorzej przedstawiala się sprawa dotacji państwowych dla kapituły, należnych w miejsce zabranych przez sekularyzację dóbr. Dotacje te zostały przez ustawe kwietniową wstrzymane. Inne dochody kapitulne pozostały nadal w jej ręku, byly one jednak skromne i stanowiły drugorzędne źródło utrzymania dla członków kapituły. W r. 1876 w skali rocznej suma dochodu kapituly, okrojonego przez „ustawe obroczną", wynosiła zaledwie $15528 \mathrm{mk}{ }^{110}$. Dodać trzeba, że w kwocie tej zawarte były odsetki od kapitałów zahypotekowanych na dominiach, częściowo odsetki od funduszów memoryjnych oraz cathedraticum. Wyjątek wśród kanoników gnieźnieńskich stanowił ks. Franciszek Duliński, któremu władze wypłacały dotację, tak jak dawniej, w wysokości $4000 \mathrm{mk}$ rocznie. Była to nagroda, jaką ofiarowano ks. Dulińskiemu za jego prorządowe nastawienie i nielojalność $w$ stosunku do ciężko wówczas walczącego Kościoła ${ }^{111}$. Pozostałe pensje kanonickie, cofnięte od $3 \mathrm{kwartalu} 1879$,r. wynosiły w skali rocznej: ${ }^{112}$

105 Kur. Pozn. 1878, 29.

$106 \mathrm{P}$. H in s c hi u s, dz. c., s. 272.

107 AAGn, j. W., nr 396 (1875).

108 Tamże, nr 428 (1875).

109 AAGn, A. kap. R. 40, Gr 4 II (Akta kapituly metropolitalnej gnieźn. dot. funduszu dotacyjnego za rok 1876).

110 Kur. Pozn. 1875, 297.

111 Kur. Pozn. 1875, 148.

112 APP, j. W., D IIIb 4, vol. II, k. 44. 
- wakująca prebenda pralata prepozyta

- I kanonik, zarazem wikariusz generalny, ks. kan. Maciej Dorszewski

- dyrektor budowli katedry, ks. kan. Karol Kraus

- sufragan, ks. bp Józef Cybichowski

- I radca i penitencjarz większy, ks. kan. Walenty Wojciechowski

- II radca, ks. kan. Jan Korytkowski

- $6241 \mathrm{mk}$

- $5670 \mathrm{mk}$

- $3329 \mathrm{mk}$

- $3033 \mathrm{mk}$

$-3094 \mathrm{mk}$

- $2901 \mathrm{mk}$

Prócz tego kasa kapitulna przed ustawą kwietniową otrzymywała od władz rejencyjnych rocznie $12816 \mathrm{mk}$. Do konca kulturkampfu, czyli do roku 1886 wymienione sumy byly w oparciu o ustawe kwietniową kapitule wstrzymywane 11 .

Kapituła właściwie najsilniej odczuła ustawę kwietniową. Kanonicy byli zatrudnieni $w$ konsystorzu za co otrzymywali wynagrodzenie. Prócz tego mieli wypłacane im przez państwo prebendy kanonickie. To były dwie główne podstawy dochodu kanonickiego. Obie upadły przez ustawę z 22 IV. Pozostały więc kapitule dochody, które dotąd stanowiły jak gdyby uzupełnienie głównych źródeł utrzymania.

\section{Majątek Seminarium Duchownego}

Ustawa z 11 V $1873 \mathrm{r}$. pozostawiła władzy duchownej odnośnie seminarium tylko dwie możliwości do wyboru ${ }^{14}$. Mogła więc ona dopuścić by seminarium przekształciło się $w$ odpowiednia do dezyderatów rządu szkołę dla kształcenia duchowieństwa, albo też przyjąć drugą ewentualność - wcześniejsze lub późniejsze zamknięcie seminarium. Było rzeczą oczywistą, ze pierwsza ewentualnošć nie wchodziła w rachubę. Postanowienia ustawy o wykształceniu duchowieństwa nie dotyczyły zresztą bezpośrednio seminarium gnieźnieńskiego, gdyż był to zakład przygotowania praktycznego do kapłaństwa. $Z$ chwilą likwidacji seminarium poznańskiego, co nastąpiło jeszcze w r. 1873, nie miało seminarium w Gnieźnie jednak racji bytu, po prostu z braku kleryków. Mimo takiego stanu prawnego i perspektyw natury praktycznej, władze zainteresowały się żywo losem seminarium gnieźnieńskiego. Bezpośrednio po wydaniu ustawy z $11 \mathrm{~V} 1873 \mathrm{r}$., $27 \mathrm{~V}$ naczelny prezes Günther, opierając się na $\S 6$ ustawy $\mathrm{z} 11 \mathrm{~V}$, wezwal arcybiskupa Ledóchowskiego do przedłożenia władzom państwowym planu nauk i regulaminu obowiązującego w Seminarium Duchownym w Gnieźnie. Władze miały zadecydować, czy plan nauk i regulamin może być przez nie zatwierdzony. Arcybiskup odpowie-

113 GSS 1873 , s. $191-197$.

114 Kur. Pozn. 1873, 73 (Dosłowny przedruk korespondencji). 
dział 10 VI, że Sobór Trydencki i bulla „De salute animarum” nie przewidziały tego rodzaju interwencji państwowej $w$ sprawy seminaryjne, pozostawiając troskę o nie całkowicie Kościołowi ${ }^{115}$. Nie zważając na tę odpowiedź wysłał naczelny prezes $27 \mathrm{VI} 1873 \mathrm{r}$. do semínarium gnieźnieńskiego komisję, w skład której wchodzili: radca rejencyjny Raffel i dyrektor gimnazjum ostrowskiego Tschakert. Mieli oni zwizytować seminarium i przekonać się, o ile odpowiada ono wymogom stawianym przez ustawę z 11 V 1873 r. ${ }^{11}$ Biskup Cybichowski, ówczesny rektor seminarium, nie dopuścił do rewizji, stwierdzając, że nie może uznać prawa władz państwowych do ingerencji w wewnętrzne sprawy tego rodzaju zakładu. Gotów był jednak umożliwić wspomnianej komisji lustracje urządzeń sanitarnych seminarium. Ostatecznie więc komisja nie zdołała wykonać swego zadania, a raczej wykonała je w części, nie zdołala bowiem zwizytować wykładów, natomiast uzyskała wgląd do planu zajęć i statutów. Rektor jednak zaznaczył, że zatwierdzenie tych rzeczy przez władze byłoby bezprzedmiotowe, ponieważ państwo nie posiada tu potrzebnych kompetencji.

Wizytacja, o której mowa, byla raczej rodzajem wstępnego wywiadu. Potwierdzają to liczne pytania komisji dotyczące życia wewnętrznego i stanu seminarium. Rezultat tego wywiadu byl jednak mierny, gdyż wlaściwie nie dal on więcej, niż można by wyczytać w rubrycelli ${ }^{117}$. Zachowanie się władz seminaryjnych utwierdziło jednak naczelnego prezesa $w$ przekonaniu, że jedynym środkiem, zdolnym przeforsować na terenie seminaryjnym ustawę z 11 V 1873 r., będzie zastosowanie sankcji karnych przez ustawę przewidzianych. Byl to jednak początek kulturkampfu, nic więc dziwnego, że naczelny prezes nie chciał podejmować tego rodzaju decyzji samodzielnie. Każdego dnia szły do Berlina sprawozdania o przeprowadzonej akcji. Falk byi nią osobiście bardzo zainteresowany. Na sprawozdanie o przeprowadzonej $\mathrm{z}$ tak nikłym wynikiem rewizji $\mathrm{w}$ seminarium gnieźnieńskim, wysłane do Falka już 28 VI odpowiedział minister natychmiast i to telegraficznie, nakazując naczelnemu prezesowi natychmiastowe wstrzymanie dla seminarium gnieźnieńskiego wszelkich dotacji państwowych. Podobną metodę zalecił, gdy zajdzie potrzeba, zastosować również wobec seminarium poznańskiego ${ }^{118}$. Na razie dotyczyło to tylko tej kwoty, jaka państwo bezpośrednio płaciło seminarium. Falk widocznie

115 Księga Protokolów $i$ Kronika Seminarium Duchownego $w$ Gnieźnie, s. 43. (A.S.D. Gniezno).

116 Tamże.

117 APP. j. w., D I 4, vol. VII, k. 17.

118 Tamże, k. 18. 
rychło dostrzegł swój błąd, gdyż następnego dnia w nowym telegramie do naczelnego prezesa polecił wstrzymać również tę część dotacji seminaryjnej, jaką placiły władze poprzez kasę konsystorską ${ }^{119}$.

W sierpniu $1873 \mathrm{r}$. skierowal naczelny prezes do Seminarium Duchownego memoriał, w którym, stosownie do ustawy z $11 \mathrm{~V}$, wysuwal pod adresem tego zakładu pewne postulaty. Ich treść przechodziła wszelkie oczekiwania ${ }^{120}$. Wypadki, które nastąpiły bezpośrednio po wystosowaniu tego memoriału, każą przypuszczać, że był on po prostu prowokacją. Naczelny prezes uznal stanowczo system dyscyplinarno-wychowawczy i metodę studiów seminaryjnych w Gnieźnie za nie odpowiadające wymogom, stawianym tego rodzaju zakładom przez państwo. Naprawić ten stan rzeczy, zdaniem Günthera, mogło tylko całkowite zastosowanie się kierownictwa seminarium do ustawy z $11 \mathrm{~V}$ 1873 r. Celem dokonania tego proponowal naczelny prezes utworzyć wspólną komisje złożoną z przedstawicieli władzy duchownej i władz państwowych. Arcybiskup Ledóchowski odpowiedział jednak tak jak poprzednio. Tym samym więc dalsze rokowania na temat seminarium gnieźnieńskiego były bezcelowe, tym bardziej, że po odjęciu dotacji władze państwowe nie rozporządzały już żadnymi środkami nacisku. Pozostawała wprawdzie możnośc zamknięcia seminarium. I to jednak nie było takie proste, gdyż brakawalo do tego kroku ścisłej podstawy prawnej. W takich okolicznościach władze jeszcze raz postanowiły szukać wyjścia kompromisowego. W dniu 12 XII $18 \overline{8} 73$ r. zjawiła się ponownie w Gnieźnie komisja w tym samym co poprzednio składzie. Do wizytacji jednak $i$ tym razem rektor nie dopuścił. Informacje udzielone przez niego komisji na temat programu studiów, składu grona profesorskiego i alumnów nie wychodziły tak jak poprzednio poza wiadomości zawarte $\mathrm{w}$ elenchu. Nie był to koniec usiłowań przeprowadzeniem $\mathrm{w}$ seminarium rewizji. Próby te powtarzały się $\mathrm{w}$ roku $1874{ }^{122}$, a nawet $w 1875$. W tym ostatnim roku dni seminarium gnieźnieńskiego były już policzone, dlatego też zainteresowanie komisji rewizyjnych, w innym zreszta składzie, bo policyjnych, skoncentrowały się na innym przedmiocie. Indagowano, mianowicie, profesorów seminaryjnych na temat dzialającej $w$ obu archidiecezjach tajnej administracji ${ }^{123}$.

119 Kur. Pozn. 1873, 183. (Przedruk mémorialu).

120 Księga Protokołów..., s. 46.

121 Przegląd Katolicki 1874, s. 252.

122 Księga Protokolów..., s. 52 i 54 .

123 AAGn, A. kons., Gen. 116, vol. II. Memoriał w sprawie zarządu majątkiem należącym do Seminarium Duchownego $w$ Gnieźnie od r. 1874 do r. 1886. Zob. też Kur. Pozn. 1874, 246. 
Chociaż seminarium gnieźnieńskie istniało jeszcze prawie do polowy $1875 \mathrm{r}$. to jednak była to tylko już wegetacja. Pomijając najważniejszy moment, tzn. brak kleryków, wobec zamknięcia seminarium poznańskiego, trzeba nadmienić, ze po ustawie z $20 \mathrm{~V} 1874$ r. seminarium materialnie zostało całkowicie uzależnione od komisarza ${ }^{\mathbf{1 2 4}}$. W dniu 9 VI 1874 r. Nollau obłożył aresztem nie tylko majątek, ale cały inwentarz seminaryjny ${ }^{125}$. Zabrakło więc równieź środków materialnych na dalsze funkcjonowanie seminarium. Przez rok w seminarium pozostawalo jeszcze 10 kleryków. Falk, nie chcąc formalnie wydać nakazu likwidacji seminarium, nalegał jednak, by naczelny prezes wydalil po prostu kleryków, kładąc $w$ ten sposób kres istnieniu zakładu ${ }^{126}$. Zabiegi Falka były już jednak niepotrzebne, gdyż ostatni 10 osobowy kurs został przez biskupa Cybichowskiego rozwiązany 11 IV 1875 r. ${ }^{127}$

Od polowy roku 1874 majątek seminarium gnieźnieńskiego spoczął więc w ręku komisarza dla zarządu majątkiem arcybiskupstwa. Komisarz traktował majątek seminaryjny jako część majątku konsystorskiego, co, oczywiście, było nieporozumieniem, na które dopiero w cytowanym poprzednio memoriale z $1886 \mathrm{r}$. miała władza duchowna możność wskazać. Nieporozumienie to jednak nie wynikało wyłącznie z winy samego komisarza. Nollau, a także Perkun dzialali na ogól ostrożnie. Nawet $w$ błahych sprawach udawali się po instrukcje do władz nadrzędnych. Rzecz w tym, że i tam starano się skomplikowane sprawy zarządu majątkiem kościelnym jak najbardziej uprościć.

Dwie szczególnie sprawy dotyczące majątku seminaryjnego, załatwiane przez komisarza, stanowią ciekawy i charakterystyczny obraz działania biurokracji pruskiej. Otóż kapituła gnieźnieńska, od czasów arcybiskupa Karnkowskiego, placila na rzecz Seminarium Duchownego w Gnieźnie procent od kapitału, który w czasach pruskich wynosił 4000 talarów (12000 mk). Był to kapitał za wykup od seminarium połowy przedmieścia Gniezna (Cierpięgi). Procent ten w $1874 \mathrm{r}$. wynosil $420 \mathrm{mk}$ rocznie. W marcu $1877 \mathrm{r}$. naczelny prezes polecil kapitule wstrzymanie wypłacania tego procentu na konto seminaryjne. Było to faktycznie korzystne dla kapituły, nie szkodziło te $\dot{z}$ wprost interesom seminaryjnym. Ciekawe jednak, że władze wbrew prawu zdecydowały się na uszczuplenie majątku seminaryjnego, co więcej

124 Księga Protokołów.., s. 50 pkt 1 i 2.

${ }_{125}$ APP, j. w., D IIIa 93, vol. I. Pismo min. wyzn. do naczelnego prezesa $z$ dnia 6 VII $1875 \mathrm{r}$.

126 Księga Protokołów..., s. 54.

127 APP, j. w., D I 14, vol. II, k. 45. 
brał w tym udział komisarz, który wyznaczony był głównie dla strzeżenia całości powierzonej sobie masy majątkowej ${ }^{\mathbf{1 2 8}}$.

Równolegle czasowo toczyla się inna sprawa. Komisarz, a raczej jego zastępca Perkun, znający dosyć dobrze warunki gnieźnieńskie, wyśledził, że ks. prałat Zienkiewicz przekazał w testamencie Seminarium Duchownemu legat $w$ wysokości $150,0 \mathrm{mk}$. Zahypotekowano go na gruncie niejakiego Walkowskiego. O istnieniu legatu doniósł Perkun bezpośrednio naczelnemu prezesowi, pomijając swego zwierzchnika Massenbacha. Perkun dowiedział się nadto, że procenty od wspomnianego legatu pobieral nadal prokurator Seminarium Duchownego w Gnieźnie ks. Ziólkowski. Zwrócił więe uwagę naczelnego prezesa na to, że pieniądze te należy zabrać do kasy zarządu komisarycznego ${ }^{129}$. W 5 dni po tym donosie naczelny prezes zagroził biskupowi Cybichowskiemu karą $100 \mathrm{mk}$, gdyby ten nie oddał odcinka hypotecznego komisarzowi Massenbachowi(!), a procenty polecil wpłacać do kasy komisarskiej ${ }^{130}$. W kwietniu 1877 r. Massenbach doniósł naczelnemu prezesowi, że biskup Cybichowski uczynił zadość stawianym mu żądaniom ${ }^{131}$.

Bardziej charakterystycznym rysem "opjeki" komisarza nad majątkiem seminaryjnym jest transakcja, która znacznie zubożyła majątek tej instytucji. Jeszcze w czasie komisorium Nollaúa rozpoczęto w majątku seminaryjnym Braciszewie budowę zabudowań gospodarczych. Ukończył ją Perkun. W sumie koszt tych prac wyniósł 112161 mk. Prawnie winien to pokryć fiskus, który po sekularyzacji dóbr biskupich, przejął piastowany poprzednio przez arcybiskupa patronat budowlany nad seminarium. Sprawa ta przedstawiała się o tyle korzystnie dla seminarium, że w $1850 \mathrm{r}$. arcybiskup Przyłuski wygrał $\mathrm{w}$ tej właśnie kwestii proces $\mathrm{z}$ naczelnym prezesem Beurmannem. Zobowiązań patronackich nie wzięli jednak pod uwagę, ani komisarz, ani jego zwierzchnicy. Skutkiem tego, kosztami budowy obciążono majątek seminaryjny. Przeciętny dochód z dzierżawy majątku Braciszewo wynosił rocznie $4500 \mathrm{mk}$. Natomiast $5 \%$ od sumy zainwestowanej przez komisarza wynosiła $5600 \mathrm{mk}$. Żeby więc wyrównać niedobór, komisarz zużytkował część kapitałów abluicyjnych, wynoszących łącznie $62325 \mathrm{mk}$. Z tego na cele budowy zebrano $32838 \mathrm{mk}^{132}$.

Te przykłady wskazują wyraźnie na niekorzystne dla seminarium, szczególnie dla jego stanu posiadania, warunki stwarzane przez nową

${ }_{128}$ APP, j. w., D IIIa 97, vol. II, k. 33-34.

128 Tamże, k. 36.

130 Tamże, k. 40.

131 AAGn, A. kons., Gen 116, vol. II. Memoriał... (zob. przyp. 123).

132 APP, j. w., D I 11, vol. I, k. $12 \mathrm{nn}$. 
formę zarządu majątkowego. Widać też, jak małą rolę odgrywały faktyczne przepisy prawne, jeśli przemawialy one na korzyść instytucji kościelnej. Przecież komisarz nie miał faktycznie prawa tego rodzaju dyṣponowania majątkiem seminaryjnym, tym bardziej, że w grę wchodziła tu jeszcze sprawa patronatu budowlanego fiskusa.

$\mathrm{Z}$ dotacji, jakie państwo przed kulturkampfem dawało na rzecz seminarium płacono tylko pensje profesorom. Wedlug etatu z $1874 \mathrm{r}$. wynosiły one łącznie $3264 \mathrm{mk}^{133}$. Usiłowano zresztą profesorom tę pensję odjąć. Trzeba było dopiero interwencji w ministerstwie $i$ wykazania, że ustawa z 22 IV 1875 r. nie odnosiła się do personelu seminaryjnego ${ }^{134}$.

Prócz dotacji ściśle państwowych zatrzymano też seminarium $750 \mathrm{mk}$ rocznego funduszu stypendialnego gnieźnieńsko-żnińskiego ${ }^{135}$.

Przekazując w maju 1886 r. majątek seminaryjny władzom duchownym, nie oddał komisarz, ani naczelny prezes, mimo monitów, rachunków i akt wytworzonych przez zarzad komisaryczny ${ }^{136}$. Widocznie władze państwowe miały również wątpliwości co do strony prawnej poczynań komisarza na terenie majątkowych spraw seminaryjnych. Ekstradycja akt nie miałaby zresztą praktycznego znaczenia, gdyż wyrządzonych tu w czasie kulturkampfu szkód państwo bynajmniej nie mialo zamiaru naprawić.

\section{Instytucje charytatywne}

Zagadnienie to dotyczy tylko ubocznie spraw związanych z zarządem majątkowym archidiecezji gnieźnieńskiej w czasie kulturkampfu. Majątki bowiem wszystkich instytucji charytatywnych, jak szpitali, achronek administrowane były niezależnie od władzy duchownej przez odpowiedni dozór. A archidiecezji gnieźnieńskiej arcybiskup miał tu wprawdzie władzę zwierzchniczą, polegała ona jednak wyłącznie na kontrolowaniu działalności dozoru. $\mathrm{Na}$ terenie archidiecezji istniało kilka domów sierot prowadzonych przez siostry zakonne, przeważnie Siostry Miłosierdzia św. Wincentego à Paulo. Akcja przeprowadzana przez rząd wobec zgromadzeń zakonnych po ustawie o zakonach z 31 V $1875 \mathrm{r}$. doprowadziła przede wszystkim do wyeliminowania $\mathrm{z}$ pracy w ochronkach, domach sierot i innych zakładach dydaktyczno-wychowawczych sióstr zakonnych, co pociągało za sobą przeważnie zamykanie

133 Kur. Pozn. 1875, 297.

134 APP, j. w., D IIIb, 4, vol. II k. 169-179.

135 AAGn, A. kons., Gen. 116. Memoriał...

136 GSS 1875, s. 217-218. Gesetz uber die Geistlichen Orden und ordensähnlichen Kongregationen der kath. Kirche. Vom 31 V 1875. 
tych zakładów ${ }^{137}$. Celem władz nie było zapewne likwidowanie tego rodzaju instytucji, następowało to po prostu z braku odpowiedniego personelu po odsunięciu zakonnic ${ }^{138}$. Najgorliwiej zajęły się władze pruskie szpitalem św. Jana $w$ Gnieźnie i Ochronką św. Wojciecha $\mathrm{w}$ tym samym mieście. $W$ obu przypadkach obserwować można planowo przeprowadzaną przez władze akcję. Ze szpitalem św. Jana w Gnieźnie sprawa była w zasadzie prosta. Powstał on z resztek fundacji sekularyzowanego zakonu Bożogrobców $\mathrm{z}$ Miechowa. Rejencja bydgoska zastrzegła sobie prawo nadzoru majątkowego nad szpitalem. Administrację majątku szpitalnego sprawowal stale dozór potwierdzany przez arcybiskupa gnieźnieńskiego. W dniu 10 VII 1874 r. komisarz Nollau, powołując się na złożonie przez Trybunał dla Spraw Duchownych arcybiskupa $\mathrm{z}$ urzędu, zawiadomil dozór szpitala, że kadencja jego się skonczyła. Komisarz $\mathrm{w}$ ogóle zrezygnował na przyszłość z pomocy dozoru $\mathrm{w}$ administrowaniu majątkiem szpitalnym ${ }^{139}$. W r. 1875 Nollau zaczął wprowadzać zmiany $\mathrm{w}$ organizacji szpitala. Było to konieczne ze względu na nową formę zarządu, która wymagała zmiany statutów. W tych poczynaniach szukał Nollau rady u kapituły gnieźnieńskiej ${ }^{140}$. Nie wiadomo, z jakim skutkiem, w każdym razie szpital pozostal pod zarządem komisarycznym do końca kulturkampfu. W r. 1883 komisarz Perkun skłonił ministerstwo wyznań do udzielenia pozwolenia na zaangażowanie do pracy w szpitalu sióstr zakonnych. W tym celu sprowadzono z Nysy Elżbietanki. Tych sióstr rząd nie potrzebował się obawiać, gdyż siłą rzeczy nie miały one nic wspólnego $z$ polskością ${ }^{141}$

Z większą dokładnością można przedstawić losy Ochronki św. Wojciecha w Gnieźnie. Ochronka, ta zbudowana dzięki fundacji ks. Kozłowskiego, na początku lat osiemdziesiątych XIX w. była zakładem dobroczynnym, zajmującym się wychowanie sierót wyznania kotolickiego. Prowadziły ją Siostry Miłosierdzia. Zarząd jednak spoczywal w ręku specjalnego dozoru, zwanego tu kuratorium, złożonego $\mathrm{z}$ świeckich i księży. Wartość ogólna całego stanu posiadania Ochronki szacowana była w r. 1877 na około 30 0,00 talarów, czyli $90000 \mathrm{mk}^{142}$. W tym suma kapitałów zahypotekowanych. $\mathrm{z}$ których Ochronka pobierała procent

137 Kur. Pozn. 1874, 47 i 165.

138 Kur. Pozn. 1874, 155. Informacje prasowe są tu jedynym źródłem gdyż archiwaliów do tej sprawy nie udało się odnaleźć.

139 AAGn, A. kap., O 30 Gr 4 II, nr 374 i 513 (1875) oraz 93 (1876).

140 Przegląd Katolicki R. XXI, s. 729.

141 Kur. Pozn. 1877, . 39. Prawdopodobnie oszacowano tu również wartość nieruchomości.

142 AAGn, Akta Ochronki św. Wojciecha w Gnieźnie. Fasc. 1. Pismo komisarza Massenbacha z dn. 20 VI 1877. 
wynosiła $18689 \mathrm{mk}^{143}$. Ustawy z dnia 20 VI 1875 r. i 7 VI 1876 r. dotyczące zarządu majątku parafialnego i instytucji kościelnych zostały z konieczności przez Kościół uznane, przynajmniej o tyle, że pozwolono świeckim katolikom brać udział w zarządzie majątkiem gmin katolickich, a co za tym idzie komunikować się $w$ tych sprawach z państwowymi władzami nadzorczymi ${ }^{144}$. Dozór Ochronki gnieźnieńskiej podporządkował się więc nowym prawom dotyczącym zarządu majątkiem kościelnym. Powinno go to bylo w zasadzie uchronić przed próbami jakiejś szczególnej interwencji władz w sprawy Ochronki. W ogóle natomiast upadały tu kompetencje komisarza do zarządu majątkiem arcybiskupim. Okazało się jednak, że te rachuby zawiodły. W lutym 1877 r. radca rejencyjny Perkun oświadczył zarządowi Ochronki, że uważa za konieczne ułożenie dla tego zakładu nowego statutu. Celem tego posunięcia miało być pozbawienie Ochronki jej charakteru wyznaniowego. Widać to choćby z pertraktacji o zmianę nazwy tej instytucji. Brzmiała ona: „Katolicka Ochronka dla sierót i małych dzieci u św. Wojciecha w Gnieźnie"145. Propozycie władz, rzekomo dyktowane chęcią skrócenia tak długiej nazwy, wskazywały na inną, mianowicie: „Ochronka Kozłowskiego" ${ }^{46}$. Sprawę nazwy można ostatecznie zbagatelizować. Istotne zamiary władz mialy głębszy sens. Ujawniły się one przy pertraktacjach dotyczących nowego statutu Ochronki. Dla zdobycia argumenu rzeczowego, komisarz Massenbach wystosował 20 VI 1877 r. pismo do zarządu Ochronki, nakazując przekazać sobie wszystkie agendy majątkowe zakładu. Miało to nastąpić w terminie 14 dniowym 147. Praktycznie rzecz biorąc było to polożenie przez komisarza na majątku Ochronki aresztu ${ }^{148}$. Dozór Ochronki nie miał jednak zamiaru spełnić życzenia komisarza, o czym powiadomil tego ostatniego pismem z dnia 4 VII 1877 r. Podpisali to pismo tylko księża będący zarazem kuratorami Ochronki (ks. Dorszewski, ks. Ziółkowski i ks. Dyament), brak natomiast podpisów kuratorów świeckich ${ }^{149}$. Na początku września 1877 r. komisarz zawiadomił ks. Dyamenta, że o negatywnej postawie dozoru będzie musiał zawiadomić naczelnego prezesa i prosić go o wyznaczenie odpowiednich sankcji ${ }^{150}$. Jednocześnie

143 Sprawę tę szerzej potraktowano w przytoczonym już artykule. Zob. s. 2.

144 AAGn, j. w., pismo nacz prez. z dn. 28 III $1878 \mathrm{r}$.

145 Tamże. Niemieckie brzmienie projektowanej nazwy Ochronki: Kozlowskische Anstallt.

140 AAGn, j. w., pismo Massenbacha z dn. 20 VI 1877 r.

147 AAGn, A. kap. O $30 \mathrm{Gr} 4$ II, $\mathrm{nr} 152$ (1877).

148 AAGn, Akta Ochronki św. Wojciecha, j.w., pismo z dn. 4 VII 1877.

${ }_{149}$ Tamże, pismo z dn. 4 IX $1877 \mathrm{r}$.

150 Tamże. Protest dozoru Ochronki do naczelnego prezesa. 
władze starały się nadal o zmianę statutu Ochronki W listopadzie komisarz ostatecznie ułożył projekt nowego statutu. Uwzględnił tutaj zupełnie mylnie ustawę o zakonach z $31 \mathrm{~V} 1875 \mathrm{r}$ i ustawę o zarządzie opróżnionych biskupstw z $20 \mathrm{~V} 1874 \mathrm{r}$. Ochronka przecież nigdy nie była ani zakładem zakonnym, ani biskupim Na tych motywach oparł też dozór swój protest przeciwko projektowi nowego statutu 151. Projekt ten przewidywał $w$ punkcie 3 i 4 , że zakład ma być poddany zwierzchniej władzy każdorazowego arcybiskupa, lub jego zastępcy. Przyjmowanie dzieci miało się odbywać po zasięgnięciu opinil miejskiej deputacji dla spraw ubogich; wreszcie, opieka nad dziećmi nie mogła być sprawowana przez osoby zakonne ${ }^{152}$. Tendencyjność tych żmian jest aż nazbyt widoczna. Wzmianka $w$ punkcie 3 o roli arcybiskupa, lub jego zastępcy miała otworzyć legalną furtkę dla komisarza, by mógł swobodnie interweniować $w$ sprawy zakładu. Treść punktu $4 \mathrm{w}$ istocie pozbawiała zakład charakteru katolickiego $\mathrm{i}$ to nie tylko przez usunięcie zakonnic, ale bardziej jeszcze przez odpowiedni dobór dzieci różnych wyznań, o co dbać miała miejska deputacja dla spraw ubogich.

Przeprowadzenie w praktyce dezyderatów państwowych szło dosyć opornie. Przez cały rok 1878 trwała wymiana zdań na temat przyszlego statutu Ochronki, i to zarówno między władzami państwowymi różnych szczebli, jak i między komisarzem i kuratorium Ochronki. Całą sprawę $\mathrm{w}$ tym ostatnim przypadku komplikował fakt, że kuratorium to, jak zresztą wszystkie dozory kościelne, unikało starannie urzędowego kontaktu z komisarzem. Najczęściej więc pośredniczyć tu musiał landrat gnieźnieński ${ }^{153}$.

Ostatecznie sprawę Ochronki załatwiono na początku r. 1879. W lutym wydano nowy statut. Najciekawsze były w nim punkty 3 i $9-12$. Zgodnie $\mathrm{z}$ ich treścią zarząd Ochronki powierzono dozorowi złożonemu z. trzech osób. Statut stwierdzał dalej, że zakład przeznaczony jest dla dzieci katolickich, dozór może jednak zezwolić na przyjmowanie też dzieci innych wyznań. W sprawach religijnych zakład miał podlegać kontroli arcybiskpa. Państwu zagwarantowano prawo ogólnej kontroli ${ }^{154}$. Statut zyskał zatwierdzenie królewskie w dniu 22 I 1879 r. Specjalnym rozkazem gabinetowym nadano Ochronce prawa korporacyjne. INatychmiast po ukazaniu się statutu, 14 II, komisarz zawiesił w urzędowaniu stary dozór, co oznaczało wykonanie poprzedniego nakazu z 20 VI 1877 r., sprawy Ochronki przejął bowiem komisarz osobiście ${ }^{155}$.

151 Tamże. Projekt statutu.

159 Tamże, pismo nacz. prez. do landrata Nollaua $z$ dn. 28 IV $1878 \mathrm{r}$.

153 Tamże. Statut.

154 Tamże ,pismo $\mathrm{z}$ dn. 14 II $1879 \mathrm{r}$.

155 Tamże. List ks. Dyamenta do hr. Źółtowskiego z dn. 17 II 1879 r. 
Już jednak 17 II dozór w składzie: hr Żółtowski, ks. Ziółkowski i ks. Dyament przejął ponownie agendy majątkowe Ochronki ${ }^{156}$.

Nowy statut Ochronki był właściwie kompromisowy. W stosunku do pierwotnego projektu władze państwowe poczyniły pewne ustępstwa. Pozostały jednak i pewne przemilczenia i sformułowania dwuznaczne, które w niedalekiej przyszłości miały wydać upragnione przez władze owoce. O zakonnicach nie było w statucie ani słowa. Już jednak 19 II a następnie 11 III 1879 r. rejencja bydgoska monitowała zarząd Ochron$\mathrm{ki}$, by ten postarał się o świeckie wychowawczynie, gdyż zakonnice w najbliższej przyszłości winny być zwolnione. Dozór odpowiedział 20 III, motywując konieczność zatrzymania zakonnic brakiem odpowiednich sił świeckich. Nie było to przesadą, szczególnie jeśli weźmie się pod uwagę krótki termin, jaki dano dozorowi ${ }^{157}$. W obronie sióstr wystąpiło również społeczeństwo katolickie Gniezna i to nie tylko polskie. Skierowano w tej sprawie petycję do ministra Falka. W wyniku tych starań w marcu 1879 r. przesunięto nieco termin wydalenia sióstr ${ }^{158}$. Odwołano też wypowiedzenie, jakie siostry poprzednio już otrzymały ${ }^{159}$. Ostateczna decyzja Falka nadeszła jednak rychlej, niż się spodziewano, bo już 21 IV 1879 r. Minister zakomunikował dozorowi, że siostry nie będą mogły dłużej pracować w Ochronce, gdyż ustawa z $31 \mathrm{~V} 1875 \mathrm{r}$. dozwala jedynie na pielęgnowanie przez zakonnice chorych. Falk zaznaczył, że zwolnienie sióstr z Ochronki nie oznacza bynajmniej wydalenia ich $\mathrm{z}$ miasta ${ }^{\mathbf{1 6 0}}$. Zgodnie $\mathrm{z}$ orzeczeniem ministra wyznań magistrat gnieźnieński wydał 4 VI 1879 nakaz, by siostry opuściły Ochronkę. W trzy dni później pođobny werdykt wydały bydgoskie władze rejencyjne. Ostatecznie więc siostry musiały Ochronkę opuścić, a opiekę nad dziećmi powierzono wychowawczyniom świeckim.

Sprawę Ochronki gnieźnieńskiej omówiono tu przykładowo. W czasie kulturkampfu zlikwidowano bowiem na terenie archidiecezji wszystkie tego typu placówki zakonne. Godnym podkreślenia w przedstawionym przypadku jest fakt, że władze potrafiły nagiąć do swego planu nie tylko pewne okoliczności, ale nawet, zdawały się sztywne i jednoznaczne $w$ zasadzie ustawy. Tak uczyniono tu $z$ ustawą

${ }^{156}$ Tamże. Korespondencja rej. bydg. $\mathrm{z}$ dozorem $\mathrm{z}$ dn. 11 III i 20 III 1879 r.

157 Kur. Pozn. 1879, 65.

158 Kur. Pozn. 1879, 15.

159 AAGn, Akta Ochronki św. Wojciecha, j. w., pismo Falka z dnia 21 IV $1879 \mathrm{r}$.

160 Tamże, pismo magistratu gnieźnieńskiego $\mathrm{z}$ dn. 4 VI $1879 \mathrm{r}$. Zob. też Kur. Pozn. 1879, 131. 
z $20 \mathrm{~V} 1874 \mathrm{r}$. i częściowo z ustawą $31 \mathrm{~V} 1875 \mathrm{r}$., traktującą o zakonach. Ten sposób postępowania nie był tu jednak wyjątkiem, można raczej powiedzieć, że był on jedną z cech ogólnych kulturkampfu.

\section{Rozdzi a II \\ Sytuacja materialna duchowieństwa w świetle tzw. „ustawy obrocznej” z dnia 22 IV 1875 r.}

\section{Uposażenie parafii przed wybuchem kulturkampfu}

Dla uniknięcia nieporozumień trzeba zaraz na wstępie zaznaczyć, że beneficjum, czyli uposażenie proboszcza, było w owym czasie zupełnie odrębną jednostką majątkową od kasy parafiainej. Do ustawy Landtagu pruskiego z 20 VI $1875 \mathrm{r}$. o zarządzie majątkiem w gminach katolickich administracja obu mas majątkowych skupiała się praktycznie $w$ ręku proboszcza, z tym, że $w$ zarządzie majątkiem parafialnym pomagał dozór ${ }^{1}$. Wspomniana ustawa przekazała pod administrację dozorów, inaczej teraz ukonstytuowanych, ze świeckim przewodniczącym (dawniej był nim proboszcz), cały majątek parafii, łącznie $z$ beneficjalnym. W nowym dozorze proboszcz był tylko jednym z członków ${ }^{2}$.

Majątek beneficjalny składał się zasadniczo z 5 podstawowych źródel dochodu: z majątku ziemskiego, z kapitałów, z ofiar za posługi religijne (iura stolae), $\mathrm{z}$ dziesięcin, $\mathrm{z}$ dotacji państwowych.

a. Majątek ziemski. Trudno ustalić nawet przeciętną wysokości tego typu dochodu. Najlepsze w tym przypadku źródło - kontrakty dzierżawne nie zawsze wymieniają ogólną wartość przedmiotu dzierżawy i całokształt dochodu, jaki $\mathrm{z}$ niego płynął. Podawane $\mathrm{w}$ kontraktach wysokości dzierżaw były czẹsto faktycznie niższe w rozrachunku. Można więc podać jedynie cyfrę orientacyjną, sondażową, biorąc pod uwagę parafie typowe pod względem uposażenia dla jakiejś wiẹkszej grupy $W$ omawianym przypadku otrzymamy tą drogą cyfrę $2800 \mathrm{mk}$ rocznego dochodu ${ }^{3}$.

1 WAPB (Wojewódzkie Archiwum Państwowe w Bydgoszczy), A. kośc. par. (Akta kościelne parafii) Chomentowo 2. Instrukcja dla dozorów parafialnych z r. 1871, § 75 .

${ }^{2}$ GSS 1875, s. 241 nn., $\S \S 5$ i 6 oraz $\S 8$.

3 Wzięto tu pod uwagę 8 parafii::

Mrocza - $5240 \mathrm{mk}-$ rok 1875, WAPB, A. kośc. par. Mrocza, 73.

Kcynia $\quad-5266 \mathrm{mk}$ - rok 1879, WAPB, Rep. 2 IIa 716. 
b. Kapita 1 y. W wielu parafiach stanowiły one poważną pozycje w budżecie. Większość kapitałów beneficjalnych była pod bezpośrednim zarządem proboszcza. Jedynie skapitalizowane legaty mszalne często administrował dozór parafialny, chociaż dochód z nich pobierał proboszcz, lub kapłan wypełniający zobowiązania legatowe 4 . Wartość realna kapitałów, wyrażająca się w odsetkach była jeszcze mniej stała niż to miało miejsce przy należnościach dzierżawnych, czy wartości ıposażenia gruntowego $\mathrm{w}$ ogóle. Zależała ona $\mathrm{w}$ głównej mierze od sposobu lokowania i obracania kapitałami ${ }^{5}$. Posługując się znowu sondażem, jak $w$ poprzednim przypadku uzyskamy średnią ok. 1150, mk dochodu. Jak widać $z$ przytoczonego zestawienia parafii wziętych tu pod uwagę, rozpiętość $w$ wysokości posiadanych przez nie kapitałów była znaczna ${ }^{6}$.

c. Ofiary za posługi religijne (iura stolae). Część tych ofiar należała do kasy parafialnej. W etacie część ta nosi nazwę akcydensów. Reszta pod określeniem iura stolae należała do proboszcza. Wielkość akcydensów i części proboszczowskiej zależna była nie tylko od wielkości parafii, ale w większej mierze od jej zamożności. Ludność wszystkich parafii podzielona była pod względem opłat za posługi religijne na 9 klas. Każda z nich miała osobną taksę. Dla przykładu podajemy rozpiętość między klasą I i IX.

Glesno - $2802 \mathrm{mk}$ - rok 1879, WAPB, A. kośc. par. Glesno, 73.

Nakło - $2800 \mathrm{mk}$ - rok 1870, Archiwum par. Nakło, O 1 F. 1,1.

Chelmce $\quad-2253 \mathrm{mk}$ - rok 1877, WAPB, Rep. 2 IIa, 805.

Bydgoszcz - $1576 \mathrm{mk}$ - rok 1874, Archiw. par. farnej w Bydg., vol.

Gębice - $1433 \mathrm{mk}$ - rok 1875, WAPB, Rep. $2 \mathrm{IIa}, 805$.

Dembowo - $1039 \mathrm{mk}$ - rok 1880, WAPB, A. kośc. par Demb. XII/5

${ }^{4}$ Dla przykładu cytujemy akta legatowe par. Nakło, O 1 F. 1,1. Podobne akta istnialy $w$ każdej parafij.

5 Dowodem tego może być choćby oprocentowanie kapitalów z 2 różnych parafii: Clesno w r 1879 miało $4725 \mathrm{mk}$ kapitału, dającego rocznego dochodu $148 \mathrm{mk}$ i 20 fenigów, co przeciętnie wyraża się w odsetkach 3,5 procentami. Parafia Nakło w r. 1879 miała kapitał w wysokości $5349 \mathrm{mk} z$ dochodem rocznym $282 \mathrm{mk}$ i 50 fenigów. Procent wynosil tu więc przeszło $5 \%$.

6 Wzięto tu pod uwage 6 parafii:

Bydgoszcz - $2723 \mathrm{mk}$ rok 1874, Archiwum par. far. w Bydg. vol. I.

Kcynia - $2626 \mathrm{mk}$ rok 1879 , WAPB Rep. $2 \mathrm{IIa}, 716$.

Mrocza - $10,33 \mathrm{mk}$ rok 1879, WAPB, A. kośc. par. Mrocza, 73.

Dembowo - $264 \mathrm{mk}$ rok 1880, WAPB, A. kośc. par. Dembowo, XII/5

Nakło - $282 \mathrm{mk}$ rok 1870, WAPB, Arch. par. Nakło O 1 F. 1,1.

Glesno - $148 \mathrm{mk}$ rok 1879, WAPB, A. kośc. par. Glesno, 73.

Przytoczone wyżej sumy oznaczają roczny dochód z procentów od kapitałów. 


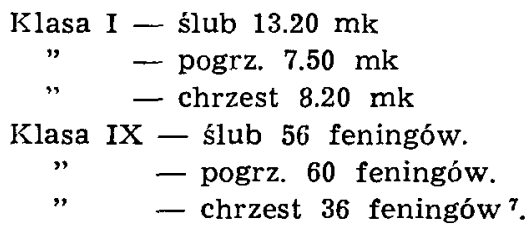

Przeciętna sondażowa wpływów za iura stolae wynosiła w okresie kulturkampfu $362 \mathrm{mk}^{8}$.

d. Dziesięcin y. Dziesięciny były najczęściej skapitalizowane, chociaż istniały tez we formie realnej, najczęściej w zbożu i drewnie, rzadziej w jarzynach. A'kta dotyczące dziesięcin w latach 70-tych XIX w. są bardzo niekompletne, udostępniają więc dane raczej fragmentaryczne. Dla przykladu przytoczmy liczby dotyczące powiatów wrzesińskiego j pleszewskiego ". Powiaty te łącznie obejmowały 58000 katolików i oddawały dziesięciny o łącznej wartości $13447 \mathrm{mk}$. Przeciętnie więc na każdego katolika przypadała tu dziesięcina wartości 23 fenigów. W skali parafialnej, biorąc pod uwage 4 parafie $z$ innego zupelnie terenu: Bydgoszcz, Mrocza, Glesno i Dembowo uzysiamy na jednego parafianina dziesięcinę $\mathrm{w}$ wysokości 21 fenigów ${ }^{10}$. Widać więc, że przeciętna $w$ tych dwóch przypadkach jest do siebie bardzo zbliżona.

e. Dotacje rządowe. Dochody z dotacji należy przede wszystkim podzielić według ich pochodzenia $z$ poszczególnych kas państwowych. Wchodzą tu w rachubę:

- kasa rejencji bydgoskiej,

- kasa rejencji poznańskiej i

- kasa rejencji kwidzyńskiej.

7 WAPB, A. kośc. par. Mrocza, 81. Tabela oplat za iura stolae. Bydgoszcz

8 Wzięto tu pod uwagę 7 parafii:

Kcynia

Chermce

Mrocza

Gębice

Dembowo

Glesno

Liczebność parafii według Elenchus omnium ecclesiarum... Archi-Dieocesis Gnesnensis 1873, s. 15-27.

9 AAP, N.P. XXIV, D IIIe 5 Zasummenstellung des an Geistlichen abzuliefernten Messkorns und Realdecens. Jahr 1870.

10 WAPB, A. kośc. par. Mrocza, 73, par. Glesno, 73, par. Dembowo XII/5 i Arch. par. farnej w Bydgoszczy, vol. I (Etaty parafialne). 
Ważna jest również sprawa tytułu, z jakiego dotacje płacono. W rejencji bydgoskiej istniały dotacje jako:

- dodatki do uposażenia duchownych katolickich i kościołów. Rozdzial etatu organizacyjnego 116 , tyt. $1 .^{11}$ przewidywał $w$ stosunku do archidiecezji gnieźnieńskiej tego rodzaju dotację $w$ łącznej wysokości $21661 \mathrm{mk} 48$ fenigów, wypłacone w 25 pozycjach płatniczych na rzecz parafii, duchowieństwa parafialnego i dziekanów ${ }^{12}$.

- Jako fundusz przeznaczony na polepszenie materialnego położenia duchownych (rozdz. etatu org. 127, tyt. 3) wypłacano 4 proboszczom lącznie $998 \mathrm{mk}$ rocznie ${ }^{13}$.

- Z nađzwyczajnych funduszów państwowych płacono $601 \mathrm{mk}$ i $95 \mathrm{fe}-$ nigów. Do tego tytułu należały fundusze na cele parafialne, pochodzące częściowo $z$ abluowanych dotacji państwowych oraz fundusz poklasztorny koronowski, z którego $420 \mathrm{mk}$ placono kościołowi parafialnemu w Solcu ${ }^{14}$.

Osobną pozycję $w$ etacie organizacyjnym stanowily fundusze budowlane kościołów i plebanii, ujęte w rodziale 31, tyt. 1 tegoż etatu. Wynosiły one w r. 1875 w archidiecezji gnieźnieńskiej łącznie $81483 \mathrm{mk} 01$ fenigów kapitalu. W tymże roku ogólny dochód od tego kapitału wynosił $8688 \mathrm{mk} 96$ fenigów ${ }^{15}$.

Dotacje $\mathrm{z}$ funduszów skapitalizowanych były następujące:

- Z funduszu leśnego i dominialnego, tytułem zaokrągleń kapitałów płacona była łącznie suma $19 \mathrm{mk} 95$ fenigów ${ }^{16}$.

- Z kapitałów kompensacyjnych (odszkodowania), należnych 26 parafiom z lasów i dominiów państwowych:

11 A. Breitfeld, dz. c., s. 304. Tytuł ogólny brzmial tu: Besoldungen und Zuschüsse für katholische Geistlichen und Kirchen. Źródła platnicze tego tytułu były bardzo liczne. Autor wymienia liczbę ogólną - 2412. Stwierdza też, że były to świadczenia, które ciążyły na państwie, jako prawne zobowiązania. Od tych więc sum państwo dla siebie nie mogło czynić oszczędności. Dla archidiecezji gnieźnieńskiej wspomniane źródła płatnicze bazowały głównie na poznańskim i zachodnio-pruskim funduszu sekularyzacyjnym. Sprawy te regulował edykt królewski z dnia $30 \times 1810 \mathrm{r}$.

12 APP, j. W., D IIIb 4, vol. II, k. 44 i vol. III, k. 14-21. Fundusz calkowity rejencji bydgoskiej na ten cel wynosił $28950 \mathrm{mk}$. W granicach rejencji była jednak część diecezji chełmińskiej, dla której z kwoty tej również pewne dotacje wypłacano.

13 WAPB. Rep. 2 IIa 187, vol. III. Nachweisung der bei den fortlaufenden Bewilligungen aus dem Fonds Cap. 127, Tit. $\overline{3}$ im Jahre 1872.

14 APP, j.w., D IIIb 4, vol III, k. 14-21.

15 APP, j. w., D I 15, k. 361.

16 APP, j. W., D IIIb, 4, vol. III, k. 14-21. 
- z dominiów państwowych w gotówce $259 \mathrm{mk} 97$ fenigów, oraz kapitały oprocentowane na $4 \% \mathrm{w}$ sumie $101700 \mathrm{mk}$.

- z lasów państwowych w gotówce $287 \mathrm{mk} 19$ fenigów oraz kapitały oprocentowane na $4 \%$ w sumie $134775 \mathrm{mk}^{17}$.

Kapitał ten pochodził $\mathrm{z}$ abluowanych przez państwo świadczeń realnych, jakie ciążyły na jego dobrach ziemskich i leśnych. Swiadczenia te były częściowo przeznaczone dla parafii, a więc wpływały do kas parafialnych, a częściowo, jako dodatek do beneficjum. Rozgraniczenie tych dwóch rodzajów dochodu, parafialnego i beneficjalnego jest trudne, ponieważ często sumy wpływające do kas parafialnych służyły również jako uzupełnienie uposażenia proboszczowskiego. W takich przypadkach kasa parafialna była tylko pośrednikiem ${ }^{18}$.

$\mathrm{Na} 16$ dekanatów $\mathrm{w}$ archiđiecezji gnieźnieńskiej 3 znajdowały się tylko w rejencji poznańskiej. Były to dekanaty: krotoszyński, pleszewski i ołobocki. Dodacje państwowe w rejencji poznańskiej dla duchowieństwa i parafii wynosiły w sumie $20089 \mathrm{mk} 51$ fenigów. Z tej sumy 3 wymienione dekanaty otrzymywaly prawdopodobnie okolo $2050 \mathrm{mk}$. $\mathrm{Na}$ polepszenie położenia materialnego duchowieństwa rejencja poznańska płaciła łącznie $6206 \mathrm{mk}$ roçznie. $Z$ tego przeciętna przypadająca na dekanaty archidiecezji gnieźnieńskiej wynosiłaby ok. $719 \mathrm{mk}$. Są to liczby podane tylko $w$ przyblizeniu. Stan faktyczny był przypuszczalnie bardziej korzystny dla archidiecezji gnieźnieńskiej, gdyż parafīe należące do trzech wymienionych dekanatów należały do gorzej uposażonych. W spisie z r. 1886 wymienia się w tych dekanatach aż 8 parafii, których całkowite uposażenie nie przekraczało $20.00 \mathrm{mk}$. rocznego dochodu ${ }^{19}$. Dla przykładu można tu podać jedną z parafii dekanatu pleszewskiego - Kuczków. Uposażenie jej wynosiło rocznie $1420 \mathrm{mk}$, a dotacja państwowa $629 \mathrm{mk} 33$ fenigi ${ }^{20}$. Trzeba jednak dodać, że z ogólnej liczby 57 parafii gorzej uposażonych w archdiecezji gnieźnieńskiej nawet $1 / 4$ nie otrzymywała żadnej dotacji państwowej.

W granicach rejencji kwidzyńskiej znajdował się tylko mały skrawek dekanatu gniewkowskiego. Swiadczenia ze strony państwa otrzy-

17 Tamże, k. 147-156.

18 Tamże, vol. II, k. 14. O takich przypadkach wspomina wyraźnie minister finansów w swej instrukcji $z$ dnia $6 \mathrm{~V} 1875 \mathrm{r}$.

19 AAGn, A. kons., Gen. (teczka bez numeru): Akta Kurii Metropolitalnej Gnieżnieńskiej. Dodatki rządowe 1886-1893. Zob. też Kur. Pozn. 1882, 250.

20 APP, j. w., A. kons. Gen. 128, k. 13 i 25. 
mywała tu tylko parafia Podgórz. Dotacja dla beneficjum wynosiła $300 \mathrm{mk}$ rocznie, dotacja dla parafii - $250 \mathrm{mk}^{21}$.

Dochody kas parafialnych były w poszczególnych parafiach bardzo zróżnicowane, tak pod względem rodzajów, jak i wysokości. Przyjmując za podstawę sondażową 7 parafii, średnia ich dochodu rocznego wynosiła ok. $923 \mathrm{mk}^{22}$. Żródła dochodowe kas parafialnych były mniej więcej podobne do tych, jakie miało beneficjum. Trzeba jedynie zaznaczyć, że dochód $z$ ziemi był tu albo minimalny, albo $w$ ogóle nie istniał. Swiadczenia z kas państwowych były tu też na ogół niewielkie, przeznaczone przeważnie na opłacenie służby kościelnej. W parafii farnej $w$ Bydgoszczy $n p$. na służbę kościelną płaciło państwo rocznie $486 \mathrm{mk}$. Z tego wyplacano pensje: kościelnemu, organiście, kalikaniście i pozostałej służbie ${ }^{23}$.

Niezbyt wysoki był też dochód kas parafialnych z tacy i akcydensów. Dla zobrazowania tego warto przytoczyć kilka cyfr:

- par. Dembowo

- par. Chelmce

- par. Glesno

- par. Kcynia

- par. Bydgoszcz

$$
\begin{aligned}
& \text { - taca - } 92 \mathrm{mk} \text { - akcydens - } 82 \mathrm{mk}, \\
& \text { - taca - } 10 \mathrm{mk} \text { - akcydens - } 107 \mathrm{mk}, \\
& \text { - taca - } 60 \mathrm{mk} \text { - akcydens - } 85 \mathrm{mk}, \\
& \text { - taca - } 74 \mathrm{mk} \text { - akcydens - } 345 \mathrm{mk}, \\
& \text { - taca - } 423 \mathrm{mk} \text { - akcydens - } 1476 \mathrm{mk}{ }^{24}
\end{aligned}
$$

Trzeba jeszcze dodać, że w granicach ogólnego dochodu parafialnego mieściły się często legaty mszalne, które właściwie nie polepszały stanu kas, gdyż były to sumy przechodnie, użytkowane zgodnie $z$ wolą fundatora, jedynie przez kasy parafialne administrowane. Mimo więc stosunkowo dużej przeciętnej, w konkretnych przypadkach kasy parafialne nie dysponowały bynajmniej większymi funđuszami. Sprawa ta jest godna podkreślenia, gdyż w czasie kulturkampfu władze państwowe wywierały nacisk ekonomiczny na dozory parafialne. $\mathrm{Za}$ odmowe np. korespondencji z władzami po niemiecku nakładano na dozory znaczne kary pieniężne, mnożyła się też korespondencja, którą

22 Wzięto tu pod uwage następujące parafie:

Bydgoszcz - $3170 \mathrm{mk}$ - Archiw, par. farnej w Bydgoszczy, vol. I, 1872-1874. Etaty prob. i kasy parafialnej.

\footnotetext{
Glesno $\quad-1781 \mathrm{mk}$ - WAPB, A. kośc. par. Glesno, 73 (1869-1874).

Kcynia $\quad$ - 960, mk - WAPB, Rep. 2 IIa, 716 (1875).

Mrocza. $\quad 520 \mathrm{mk}$ - WAPB, A. kośc. par. Mrocza, 73 (1859-1908).

Dembowo - $230 \mathrm{mk}$ - WAPB, A. kośc. par. Dembowo, XII/5 (1880).

Gniewkowo - $224 \mathrm{mk}$ - WAPR, Rep. 2 IIa, 806 vol. II. (1874), vol. III, 805, (1870-1875).

Chelmce - $187 \mathrm{mk}$ - WAPB, Rep. 2 IIa, 452 (1877-1882).

${ }^{23}$ Tamże, etaty kas parafialnych: uposażenie służby kościelnej.

24 Tamże. Liczby te obrazując tylko część akcydensu, przypadającą kasie parafialnej.
} 
trzeba było oplacać. Dla mniej zasobnych kas parafialnych sprawy te, na pozór drobne, urastały do problemów.

2. Ustawa $z$ dnia 22 IV 1875 r. $w$ odniesieniu do duchowieństwa parafialnego

Z chwila, gdy rząd pruski przekonał się, że hierarchia kościelna w Prusach stanowczo nie pójdzie na wspólpracę w wykonaniu ustawodawstwa kulturkampfu, zainteresowania jego, siłą rzeczy, skierowały się $\mathrm{w}$ stronę duchowieństwa parafialnego. Bismarck jeszcze przed kulturkampfem podkreślał niebezpieczne dla państwa, ślepe poddanie duchowieństwa niższego hierarchii kościelnej. Miał tu na myślị szczególnie duchowieństwo polskie ${ }^{25}$. W liście do ministra spraw wewnętrznych hr. Eulenburga z dnia 24 II '1872 wskazywał kanclerz na duchowieństwo wielkopolskie w ogóle, jako na głównego promotora sprawy polskiej. Miał tu Bismarck na myśli zapewne $w$ pierwszym rzędzie arcybiskupa Ledóchowskiego, chociaż w tym przypadku. zupełnie się pomylił, nawet biorąc pod uwagę obronę języka polskiego $w$ nauczaniu religii, jakiej podjął się arcybiskup nieco później w tym samym jeszcze roku. W 1884 r. sąd kanclerza na temat duchowieństwa polskiego był już bardziej skrystalizowany. Dopomogły tu doświadczenia kulturkampfu. Teraz już Bismarck wskazał właśnie na duchowieństwo parafialne, jako na glówny czynnik agitacji polskiej ${ }^{26}$. Ocena duchowieństwa parafialnego na progu kulturkampfu nie była chyba różna od tej, jaką Bismarck dał po kilkunastoletniej walce. Mimo wszystko jednak, zarówno on, jak Falk liczyli na możliwość pozyskania dla swych celów właśnie duchowieństwa parafialnego. Liczyli przede wszystkim na skuteczność represji natury materialnej, a z drugiej strony na korzyści, jakie zagwarantowano tym księżom, którzy okażą władzom uległość. Nie były to rachuby zupełnie chybione, gdyż właśnie wzgląd ekonomiczny sprawił, że kilkunastu księży zdecydowało się służyć rządowi pruskiemu ${ }^{27}$, w ogólnym rozrachunku było to jednak mało, zwłaszcza, że ci tzw. proboszczowie rządowi nie zdołali absolutnie opanować powierzonych im przez państwo parafii. Bismarck generalnie rzecz biorąc, popełnił więc błąd w obliczeniach. Po prostu nie docenił postawy duchowieństwa. Sądził, że perspektywa spokojnego posiadania dóbr materialnych, lub groźba ich odjęcia, zrobią na księżach większe wrażenie niż zagrożenie ekskomuniką.

25 Fr. K och, Bismarck ïber die Polen, Berlin 1913 s. 84.

26 Tamże, s. $89-90$.

27 J. B. K is s ling, Geschichte des Kulturkampfes im Deutschen Reiche Freiburg/Br. 1916, t. II, s. 48. 
Ustawa z 22 IV 1875 r. miała więc być czymś w rodzaju specyficznie i po prusku pojętej ,zachęty" dla duchowieństwa parafialnego, by zdecydowało się ono podporządkować ustawodawstwu kulturkampfu. Była zatem środkiem do celu.

Treść ustawy nazwanej ironicznie „obroczną" znana jest juz z poprzeđniego rozdziału. Była ona $w$ zasadzie jednoznaczna, przewidywała bowiem zawieszenie świadczeń ze strony państwa na rzecz duchowieństwa. Praktyczne skutki tej ustawy można jednak oceniać dopiero w świetle dwóch czynników, rozporządzeń wykonawczych i instrukcji władz centralnych oraz inicjatywy władz wykonawczych. Pierwsze rozporządzenie odnoszące się do ustawy z 22 IV wydał minister finansów dnia $6 \mathrm{~V} 1875 \mathrm{r}^{28}$ Wyjaśniało ono, jakie świadczenia ze strony państwa miały być, w myśl ustawy, duchowieństwu wstrzymane. Rozporządzenie $w$ drobiazgowy sposób wyszczególniało wszelkie rodzaje świadczeń. Ze względu na ich pochodzenie odróżniano następujące:

- pochodzące bezpośrednio z kas państwowych,

- pochodzące bezpośrednio z lasów państwowych (np. zobowiązania drzewne, lub prawo wypasu),

- pochodzące bezpośrednio lub pośrednio z dominiów.

Rozróżniano jeszcze świadczenia według sposobów, jakimi były uiszczane. Obojętnie więc, czy były to świadczenia płacone "w naturze, np. drzewo z lasu, zboże z dominiów, czy też serwituty, np. dostarczanie pewnej ilości furmanek, prawo użytkowania zabudowań. Ważne bylo tylko to, by świadczenia te służyły bezpośrednio do utrzymania duchownego. Nie podlegaly natomiast ustawie kwietniowej z $1875 \mathrm{r}$. świadczenia służące kultowi i wchodzące $w$ skład uposażenia służby kościelnej. Tam, gdzie świadczenia ze strony państwa płacone byly z. dzierżaw, a więc, gdzie obiekt państwowy, na którym ciążyły zobowiązania wobec Kościoła, był wydzierżawiony, dzierżawę należną Kościołowi należało w myśl ustawy z 22 IV wpłacać do kasy fiskusa.

Licząca kilka stron instrukcja ministerialna, chociaż właściwie obostrzala przepisy zawarte $w$ samej ustawie, była jednak przejrzysta i mogło się zdawać, że zastosowanie jej w praktyce nie powinno napotkać na wielkie przeszkody. Mimo to, jedną z pierwszych spraw spornych w wykonaniu ,ustawy obrocznej" była sprawa wstrzymania dotacji państwowych na pensje dla slużby kościelnej ${ }^{29}$.

28 APP, j. w., D IIIb 4, vol. II, k. 14.

29 Tamże k. 115. Po dłuższej korespondencji, dopiero w grudniu 1876 r. min. Falk zadecydował, że świadczenia na rzecz służby kościelrej w parafii Strzelno mają być wyplacane; zamiast $801 \mathrm{mk}$ i 96 fenigów wypłacano jednak tylko $674 \mathrm{mk}$ i 06 fenigów. 
Instrukcje niższych instancji państwowych, począwszy od władz rejencyjnych, były bardziej szczegółowe. Najważniejsze było w. nich to, że zobowiązywały one wladze terenowe, jak landratów, komisarzy obwodowych, burmistrzów, do przekazywania sprawozdań władzom rejencyjnym o stanie wykonania ,ustawy obrocznej" w poszczególnych parafiach. Szczególnie zwracano tutaj uwage na tytuł, z jakiego świadczenia wypływały, np. dom lub obiekt uzywane przez proboszcza. Interesowano się $w$ tym przypadku, czy należą one do Kościoła, czy są własnością państwa, czy może państwo ma w stosunku do nich chociaż prawo nadzoru. Postępowanie w stosunku do księży, gdy prawo władz było uzasadnione miało być jak najsurowsze, łącznie z wydalaniem z zajmowanej posesji. Nie wolno bylo też zawierać jakichkolwiek kontraktów najmu ${ }^{30}$.

Tak więc problem. wstrzymania świadczeń na rzecz duchowieństwa parafialnego na podstawie ustawy z 22 IV ograniczałby się przynajmniej teoretycznie, do tych przedmiotów zobowiązań państwowych, do których państwo miało jakiekolwiek prawo, czy to własności, czy też trwałego zarządu. Pamiętać jednak należy, że celem ustawy nie była regulacja stosunków majątkowych między państwem i Kościołem, lecz tylko chwilowe, dyktowane aktualnym wymogiem polityki kościelnej Bismarcka, zastosowanie represji ,wobec duchowieństwa. Konsekwentnie więc $\S 10$ ustawy kwietniowej zawieszal, stosowaną dotychczas, pomoc państwa w ściąganiu podatku kościelnego ${ }^{31}$. Rejencja bydgoska juz $3 \mathrm{~V} 1875 \mathrm{r}$ przesłała do landratów i niższych urzędów rozporządzenie, by zaniechano dalszego pobierania podatku kościelnego wraz $\mathrm{z}$ podatkiem państwowym ${ }^{32}$. Państwo do tej pory przeprowadzało też egzekucję zaległego podatku kościelnego, o ile w chwili rozpoczęcia postępowania administracyjnego przeciwko dłużnikowi zaległość jego nie przekraczała terminu 2 lat ${ }^{33}$. $\mathrm{Z}$ interwencji państwa $\mathrm{w}$ tej dziedzinie niejednokrotnie korzystano, nawet przy egzekwowaniu nie uregulowanych akcydensów ${ }^{34}$

Prawo tak interpetowane stało się jednak rychło niewygodne nawet dla państwa, szczególnie z chwilą, gdy przeforsowano ustawę z dnia 20 VI 1875 r. o zarządzie majątkiem w gminach katolickich. Podatki kościelne bowiem stanowiły poważną część dochodu kasy pa-

30 WAPB, A.m. Z. (Akta miasta Źnina), 400. Rozporządzenie rejencji bydg. z dn. 22 V $1875 \mathrm{r}$.

31 GSS 1875 , s. 341 .

32 WAPB, A.m. Z., 400. Rozporządzenie rej. bydg. z dn. 3 V 1875.

${ }^{33}$ GSS 1836 , s. 198.

34 WAPB, A.m. Ż., 317. Sprawa szewca Tomasza Derki z proboszczem żnińskim (1868 r.). 
rafialnej. Faktu tego nie brano początkowo pod uwagę. Nowy system zarządu majątkiem parafialnym, wynikający z koncepcji rządowych, musiał jednak zdać egzamin. Nie można więc było narażać dozorów parafialnych na zbyt wielkie trudności. Dlatego też komisarz do zarządu majątkiem arcybiskupim wydał 4 XII $1876 \mathrm{r}$, rozporządzenie, na mocy którego podatki przeznaczone do kas parafialnych mialy być przez państwo pobierane $w$ dalszym ciągu ${ }^{35}$.

Kolekcję ważniejszych rozporządzeń, wydanych w związku z ustawą kwietniową zamyka instrukcja ministra finansów z dnia 6 IX $1875 \mathrm{r}$. Nakazywała ona pobierać od duchowieństwa podatek klasowy i dochodowy. Od podatku mialy być tylko wyjęte dochody przez państwo zatrzymane ${ }^{36}$. Doniosłość tego rozporządzenia oceniły najszybciej władze rejencyjne w Bydgoszczy. Rozesłano tam już 21 IX 1875 r. okólniki do władz terenowych. W myśl wytycznych wladz rejencyjnych miano z zasady bezwzględnie oddalać wnioski o ulgi podatkowe, chyba że ksiądz ubiegający się o nie wyrazi gotowość poddania się ustawom państwowym. Tego rodzaju przypadki miano też niezwlocznie zgłaszać do władz rejencyjnych ${ }^{37}$. Brak dalszej korespondencji między władzami $w$ tej sprawie nie pozwala na stwierdzenie, jak faktycznie akcja ta przebiegała. Ogólna jednak znajomość sposobu pastępowania władz pruskich w czasie kulturkampfu każe przypuszczać, że ulg podatkowych nie stosowano.

W r 1876 stanowisko władz wobec duchowieństwa parafialnego było już ustabilizowane. Obie strony zdawały sobie sprawę, że celem "ustawy obrocznej" jest wymuszenie ze strony duchowieństwa uleglości wobec praw kulturkampfu. Jasnym było też, że w skutkach ustawa kwietniowa musi przynieść znaczne zubożenie duchowieństwa. Władze państwowe $w$ wykonaniu tej ustawy były wszechwładne, podczas gdy duchowieństwo praktycznie nie miało żadnej obrony. Jeśli do skutków „ustawy obrocznej” doda się masowo stosowane kary pieniężne, widać jasno jak trudna musiała być sytuacja duchowieństwa w dziedzinie materialnej. Abstrahując jednak od skomplikowanego problemu, jakim jest całoksztalt położenia materialnego kleru w czasie kulturkampfu, należy tutaj zająć się przede wszystkim bezpośrednimi skutkami ustawy kwietniowej.

s5 WAPB, A. kość. par. Mrocza 6, Rozp. komisarza z dn. 1 XII $1876 \mathrm{r}$.

36 WAPB, A.m. Z., 400. Instrukcja min. fin. z dn. 6 IX 1875 r.

s7 Tamże. Rozp. rej. bydg. $z$ dn. 21 IX $1876 \mathrm{r}$. 


\section{Straty materialne duchowieństwa parafialnego}

Ustawa z 22 IV 1875 r. wymieniała w paragrafie 1 wszystkie osoby $i$ instytucje kościelne, którym zostają odjęte świadczenia z zasobów państwa ${ }^{38}$. W paragrafie 2 wyszczególniono rodzaje dóbr materialnych, do których ustawa się odnosiła ${ }^{39}$. Odniesienie sformułowań prawnych ustawy do okoliczności, w jakich mogły być one wykonane na terenie archidiecezji gnieźnieńskiej wymaga bliższego określenia rodzajów dóbr, jakie ustawodawca mial na myśli ${ }^{40}$.

Pojęcie "duchowny" 41 miało tu zastosowanie jedynie do kapłana zaangażowanego $w$ pracy parafialnej. Jego więc uposażenie objęte było postanowieniami ustawy. Nawet gdy świadczenia państwowe dochodziły do rąk proboszcza, czy innego kapłana pośrednio np. przez kasę parafialną, miały być na mocy ustawy zatrzymane. Dochody pobierane przez duchownego $z$ racji piastowania przez niego innego urzędu np. nauczyciela religii miały być nadal wypłacane, chociaż $\mathrm{z}$ reguły pochodziły one $\mathrm{z}$ kas państwowych. Swiadczenia dla wakujących parafii były też zatrzymane, gdyż jak!kolwiek chwilowo proboszcz nie mógł z nich korzystać, to jednak posiadały one charakter uposażenia proboszczowskiego w dalszym ciągu.

Drugie określenie, wymagające wyjaśnienia to właśnie słowo „świadczenia”. W stosunku do du'chowieństwa parafialnego określenie to oznaczało wszystkie dochody parafialne, pochodzące $z$ kas państwowych i pośrednio, lub bezpośrednio przeznaczone na utrzymanie duchownego. W ustawie zresztą pojęcie to jeszcze bardziej uścielono. Była bowiem tam mowa o "świadczeniach z zasobów państwa" przez co rozumiano nie tylko dotacje pieniężne, ale również wszelką inną pomoc materialną, jakiej duchowny od państwa doświadczał ${ }^{42}$. Wszystkie te zobowiązania państwa zostały przez ustawę kwietniową uchy-

38 Tutaj przedmiotem ustawy było tylko duchowieństwo parafialne.

39 $\mathrm{W}$ tekście niemieckim doslownie: ,....bestimmte Leistungen aus staatsmitteln..." i ,Zu den Staatsmitteln gehören auch die unter dauernder Verwaltung des Staates stehenden besonderen Fonds'. Zob. cyt. ustawę.

40 P. Hinschius, dz. c., s. 510-11.

41 Tekst niemiecki: „Geistliche”. Zob. § 1 cyt. ust.

42 Niektóre parafie $w$ archidiecezji gnieźnieńskiej otrzymywały od fiskusa np. opał, lub ekwiwalent w pieniądzach, gdy ciężar realny został zamieniony na kapitał (abluicja). W parafii farnej w Bydgoszczy proboszcz otrzymywał rocznie $10 \mathrm{~m}^{3}$ drewna wartości 16 tal. i 16 sgr. Zob. Arch. par. farnej Bydg., vol. I - etaty. Nakło natomiast zamiast drewna otrzymywało kapital abluicyjny w wysokości $2100 \mathrm{mk}$, od którego pobierał proboszcz procent. Zob. Arch. par. Naklo, O 1 F. $1,1$. 
lone. Nawet kapitały abluowanych ciężarów fiskusa na rzecz Kościoła, nie będące przecież ,zasobami państwowymi”, ale stanowiące bezsporną własność instytucji kościelnych, zostały obłożone aresztem ${ }^{43}$. Wypłata tych świadczeń, które zostały dawniej przez państwo lub prywatne osoby przeznaczone na udotowanie jakiejś parafii, zatrzymana na mocy ustawy kwietniowej, mogła być dopiero wówczas podjęta, gdy zobowiązał do tego fiskusa wyrok sądowy ${ }^{44}$. Fiskus ponosić miał jednak tylko te ciężary, które przejął wraz z nabytymi dobrami, były to bowiem zobowiązania prawa prywatnego ${ }^{45}$. Poza wymienionym przypadkiem żadne inne skargi wytaczane przez osoby prawne kościelne fiskusowi o stan posiadania nie mogły być przez sądy przyjmowane ${ }^{46}$. Dopuszczalna byla jedynie forma zapytania, czy obiekt, jaki urząd uważa za podlegający państwu, a tym samym podpadający pod ustawę kwietniową, rzeczywiście do państwa należy. Nie trzeba chyba dodawać, że zapytanie takie nie rokowało dla Kościoła żadnych pozytywnych skutków prawnych.

Trzecie wreszcie określenie ustawy: „szczególne fundusze, będące pod trwałym zarządem państwa" odnosiło się do dóbr uposażeniowych Kościoła, dawniej fundowanych przez książąt, z majątku, który ustawodawstwo pruskie zaliczało do zasobów państwa, lub też, które pochodzily z sekularyzacji wszelkiego rodzaju dóbr kościelnych, w tym dóbr klasztornych i funduszów szkolnych ${ }^{47}$. Fundusze te, chociaż miały swój własny cel kościelny, a często nawet osobowość prawną, byly jednak pod wylącznym zarządem państwa. Państwo też $w$ obrębie tych celów nimi dysponowało ${ }^{48}$. Nie wchodziły tu w grę jednak fundusze, mające charakter ściśle kościelny, przejściowo tylko administrowane przez władzę komisaryczną zgodnie $\mathrm{z}$ ustawą z $20 \mathrm{~V} 1874 \mathrm{r}$. s. 300 .

43 Archiv für katholisches Kirchenrecht 36 (1876), s. 174 i 40 (1878),

${ }^{44} \mathrm{P}$. H in s chi u s, dz. c., s. 511. Cytuje tu wyrok III senatu Sądu Rzeszy $\mathrm{z}$ dn. 6 II $1880 \mathrm{r}$.

45 Tamże. Autor cytuje wyrok II senatu Sądu Rzeszy z dn. 25 I 1883 r. Zob. też wyrok sądu powiatowego $w$ Starogardzie $z$ dn. 11 IV 1876 r. przedruk w Kur. Pozn. 1876, 101.

46 Archiv für katholisches Kirchenrecht 47 (1882), s. 196.

47 GSS 1875, s. 151: Staatshaushalts-Etat für das Jahr 1875.

48 P. Hinschius, dz. c., s. 511. „Für dem Empfenger ist es aber ohne praktische Bedeutung, ob der Staat einen Zuschuss aus dem Allgemeinen Staatsfonds, oder aus besonderen, zur Disposition der Staatsregierung stehenden Fonds bewilligt". Różnica, której tu H. nie dostrzega, istniała jednak, o tyle, o ile istnieje ona między dodatkiem dawanym $\mathrm{z}$ własnych funduszów państwa, a takim, który placony jest z funduszów sekularyzacyjnych, pozostających pod administracją państwową. Jest to więc różnica formalno-prawna. 
Praktycznie rzecz biorąc, najwięcej szkód przyniosło duchowieństwu wstrzymanie dotacji państwowych wyliczonych w rozdz. 116 tyt. 1 etatu organizacyjnego. Jak już poprzednio wspomniano, świadczenia $\mathrm{z}$ tego tytułu pochodziły $\mathrm{z}$ bardzo wielu źródel ${ }^{49}$. Z tym wiąże się sprawa prawnego zobowiązania państwa do uiszczenia wspomnianych dotacji. Z braku odpowiednich źródeł trudno określić tytuły dotacji dla poszczególnych parafii. Przykładowo można wymienić tytuł aktualny $w$ wielu parafiach, mianowicie fundusze $z$ sekularyzowanych dóbr klasztornych ${ }^{\mathbf{5 0}}$. Natomiast stan faktyczny w tym względzie moina $w$ odniesieniu do archidiecezji gnieźnieńskiej częściowo odtworzyć na podstawie wniosków, jakie księża stawiali o odszkodowanie $z$ tytułu strat poniesionych $w$ czasie kulturkampfu właśnie $w$ zakresie tyt. 1 rozdz. 116 etatu organizacyjnego. Źródło to, zresztą bardzo ważne, uzupełniają zestawienia zatrzymanych świadczeń, sporządzane przez władze pruskie $w$ czasie kulturkampfu ${ }^{51}$.

$\mathrm{Z}$ dodatków, jakie należały się dziekanom archidiecezji gnieźnieńskiej, zatrzymano w czasie od kwietnia 1875 r. do maja 1886 r. w skali rocznej:

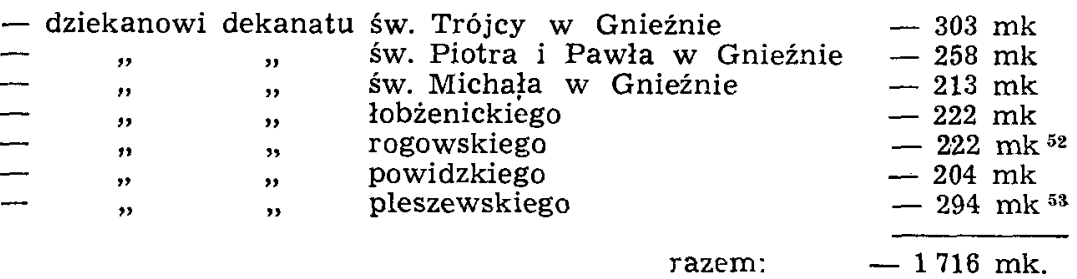

49 A. Breitfeld, dz. c., s. 304.

50 Linneborn: Rechtliche Vepflichtungen des preuss. Staatsfiskus gegenüber kath. Kirchengemeinden. Theologie und Glaube, 16 (1924), s. 27-28. Jest tu omówienie rozkazu gabinetowego $\mathrm{z}$ dn. 25 IX 1836 r., określającego prawo kościołów parafialnych do dotacji państwowej ze sekularyzowanych dóbr klasztornych, na których przed sekularyzacją spoczywały obowiązki świadczeń materialnych na rzecz pewnych parafii.

51 AAGn, A. kon. Gen. 128. Teczka zawiera 18 wniosków księży o zwrost zebranych $w$ czasie kulturkampfu dochodów. Liczba poszkodowanych była jednak znacznie większa. Można ją ustalić ze względna dokładnością, posługując się dodatkowo spisami zatrzymanych świadczeń państwowych z roku 1875 dla rejencji bydgoskiej. Nie można natomiast zastosować tej metody do 3 dekanatów położonych $w$ rejencji poznańskiej, brak tu bowiem odpowiednich źródeł.

52 APP, j. W. D IIIb 4, vol. II, k. 44.

${ }^{3}$ Tamże, k. 42 (w odniesieniu do ostatnich dwóch pozycji). 
W ciągu jedenastu lat państwo zatrzymało tu więc $18876 \mathrm{mk}$. Pozostajac dalej $w$ granicach rozdz. 116, tyt. 1 etatu organizacyjnego, trzeba podać zestawienie sum zatrzymanych parafiom. Pojęcie ,parafia", jako przedmiot świadczeń państwowych, zostało już wyjaśnione. Warto jednak i tu nadmienić, że znaczny procent przytoczonych niżej sum, aczkolwiek należał do uposażenia beneficjum, faktycznie przeznaczony byl na cele parafialne. Trudno tu, oczywiście, przeprowadzić dokładny podział na dochody parafialne i beneficjalne. $\mathrm{Na}$ ogół jednak, wyjąwszy przypadki sporne różnica tu jest dość wyraźnie zarysowana. W poszczególnych parafiach stan zatrzymanych dotacji państwowych przedstawiał się więc następująco:
a. Bydgoszcz, parafia farna,
rocznie $399 \mathrm{mk}$. Ogółem $4100 \mathrm{mk}$
b. Trzemeszno

proboszcz
wikariusz I
wikariusz II
wikariusz III
organista
kościelny
kalikanista
c. Podgórz, dot. proboszcza
d. Wągrowiec, par. poklaszt. ${ }^{5 s}$ proboszcz
wikariusz
par. farna
proboszez
wikariusz
e. Górka klasztorna
f. Eobżenica
proboszcz kasa par.
g. Kcynia ${ }^{56}$

\begin{tabular}{|c|c|c|c|}
\hline$"$ & $3000 \mathrm{mk}$ & $"$ & $31500 \mathrm{mk}$ \\
\hline$"$ & $600 \mathrm{mk}$ & $"$ & $6300 \mathrm{mk}$ \\
\hline$"$ & $450 \mathrm{mk}$ & $"$ & $4725 \mathrm{mk}$ \\
\hline$"$ & $450 \mathrm{mk}$ & $"$ & $712 \mathrm{mk}$ \\
\hline$"$ & $300 \mathrm{mk}^{54}$ & & \\
\hline$"$ & $150 \mathrm{mk}$ & & \\
\hline$"$ & $108 \mathrm{mk}$ & & \\
\hline$"$ & $300 \mathrm{mk}$ & $"$ & $3150 \mathrm{mk}$ \\
\hline$"$ & $1063 \mathrm{mk}$ & & \\
\hline " & $750 \mathrm{mk}$ & " & $7875 \mathrm{mk}$ \\
\hline$"$ & $300 \mathrm{mk}$ & $"$ & $3150 \mathrm{mk}$ \\
\hline$"$ & $750 \mathrm{mk}$ & $"$ & 7875 \\
\hline$"$ & $802 \mathrm{mk}$ & $"$ & $8423 \mathrm{mk}$ \\
\hline$"$ & $600 \mathrm{mk}$ & $"$ & $6300 \mathrm{mk}$ \\
\hline$"$ & $492 \mathrm{mk}$ & $"$ & $6300 \mathrm{mk}$ \\
\hline$"$ & $450 \mathrm{mk}$ & & \\
\hline$"$ & $20,5 \mathrm{mk}$ & $"$ & $2157 \mathrm{mk}$ \\
\hline$"$ & $750 \mathrm{mk}$ & & \\
\hline " & $600 \mathrm{mk}$ & $"$ & 6300 \\
\hline$"$ & $314 \mathrm{mk}$ & $"$ & 3302 \\
\hline
\end{tabular}
h. Moglino, wikariusz I i II
i. Wysoka, wikariusz
j. Wenecja, proboszcz
wikariusz I wikariusz II

zt.5


k. Pakość

$$
\begin{aligned}
& \text { proboszcz } \\
& \text { wikariusz }
\end{aligned}
$$

1. Gniezno, kość. pofranciszk. ${ }^{57}$

fund. mszalne

za naboż niem.

dla prob. par.

św. Trójcy za nadzór " $150 \mathrm{mk} \quad$ " $1575 \mathrm{mk}$

na koszty odpustowe

m. Duszno

n. Lubcz

o. Nakło, proboszcz

wikariusz

Markowice

q. Strzelce

r. Solec, proboszcz

$$
\text { z fund. klasztornego }
$$

s. Żón

\begin{tabular}{|c|c|c|c|}
\hline " & $\begin{array}{l}431 \mathrm{mk} \\
600 \mathrm{mk}\end{array}$ & " & $\begin{array}{l}4527 \mathrm{mk} \\
6300 \mathrm{mk}\end{array}$ \\
\hline " & $\begin{array}{l}361 \mathrm{mk} \\
477 \mathrm{mk}\end{array}$ & $"$ & $\begin{array}{l}3791 \mathrm{mk} \\
50,18 \mathrm{mk}\end{array}$ \\
\hline$"$ & $\begin{array}{l}150 \mathrm{mk} \\
150 \mathrm{mk}\end{array}$ & $"$ & $\begin{array}{l}1575 \mathrm{mk} \\
1575 \mathrm{mk}^{58}\end{array}$ \\
\hline " & $90 \mathrm{mk}$ & $"$ & $945 \mathrm{mk}$ \\
\hline$"$ & $240 \mathrm{mk}$ & $"$ & $2520 \mathrm{mk}$ \\
\hline$"$ & $\begin{array}{r}36 \mathrm{mk} \\
750 \mathrm{mk}\end{array}$ & $"$ & $\begin{array}{r}378 \mathrm{mk} \\
7875 \mathrm{mk}\end{array}$ \\
\hline$"$ & $250 \mathrm{mk}$ & $"$ & $2625 \mathrm{mk}$ \\
\hline$"$ & $240 \mathrm{mk}$ & $"$ & $2520 \mathrm{mk}$ \\
\hline " & $300 \mathrm{mk}$ & $"$ & $3150 . \mathrm{mk}$ \\
\hline$"$ & $480 \mathrm{mk}$ & $"$ & $4410 \mathrm{mk}$ \\
\hline$"$ & $33 \mathrm{mk}$ & $"$ & $347 \mathrm{mk}$ \\
\hline " & $3399 \mathrm{mk}$ & $"$ & $35689 \mathrm{mk}$ \\
\hline
\end{tabular}

koronowskiego

t. Strzelno ${ }^{59}$

Do tego należy dodać sumę przypadającą na dekanaty leżące na terenie rejencji poznańskiej. Przypuszczalna jej wysokość wynosila $2055 \mathrm{mk}^{00}$. Swiadczenia $\mathrm{z}$ rejencji. kwidzyńskiej dla parafii Podgórz zostały tu dla uproszczenia sprawy ujęte razem z rejencją bydgoską.

Rozd.z, 127 etatu organizacyjnego dla całej prowincji obejmował sumę $5058 \mathrm{mk}$ rocznej dotacji. Nie było to zbyt dużo, jeśli zważyć, że suma ta była podzielona na trzy niemal diecezje: gnieźnieńską, poznańską i część chełmińskiej. W archidiecezji gnieźnieńskiej w r. 1874 tę specjalną pomoc dla polepszenia sytuacji materialnej duchowieństwa parafialnego otrzymywało 4 proboszczów:

- ks. Weidner z Solca

$-279 \mathrm{mk}$

- ks. Kozłowicz z Ostrowa k. Pakości

- $186 \mathrm{mk}$

- ks. Chmarzyński z Podlesia kościelnego

- $36 \mathrm{mk}$

-- ks. Szymański z Kościeszek

$-496 \mathrm{mk}^{\circ 1}$.

57 Sumy tu wyliczone pośrednio służyły utrzymaniu duchowieństwa, podlegały więc ustawie z $22 \mathrm{IV} 1875 \mathrm{r}$.

38 AAGn, A. kons., Gen. 128, k. 5-229 - a.-1., z wyjątkiem d. i g.

59 APP, j. W. w odniesieniu do - m. -t.

Bo Zob. s. 45.

i1 WAPB, Rep. 2 IIa, 187, vol. III. Wykaz placonych w r. 1874 z. rozdz. 127 , tyt. 3 etatu org. świadczen. 
„Ustawa obroczna" spowodowała odjęcie wymienionym księżom tych zapomóg 62. Dotacje tego rodzaju były natomiast od r. 1875 wypłacane księżom, którzy okazali uległość ustawom majowym. Naczelny Prezes Prowincji Poznańskiej nakazał osobiście w dniu 14 XII 1875 r. wypłacać zapomogi Księżom: Brenkowi z Piasek $282 \mathrm{mk}^{63}$ i ks. Stankowskiemu z Barcina $170 \mathrm{mk}^{\mathrm{B} 4}$. Ten ostatni zresztą nie był proboszczem rządowym. W kwietniu następnego roku minister Falk przyznał proboszczowi rządowemu ks. Lizakowi z Pierania $149 \mathrm{mk}$ zapomogi stałej i $500 \mathrm{mk}$ jednorazowej ${ }^{65}$. W miarę, jak tego rodzaju księży przybywało, wyznaczano im coraz to nowe środki pomocy finansowej ${ }^{66}$.

Wracając jeszcze do rozdz. 116, tyt. 1 etatu, należy stwierdzić, że w roku 1885, w skali rocznej zatrzymano duchowieństwu archidiecezji gnieźnieńskiej $15371 \mathrm{mk}$. W przytoczonym wykazie strat parafialnych suma ogólna $w$ skali rocznej wynosi $20458 \mathrm{mk}$. Różnica wynosi tu więc ok. $5000 \mathrm{mk}$. Można to wytłumaczyć stopniową zmianą postepowania władz, szczególnie w stosunku do dozorów parafialnych. Bardziej energiczne dozory zdołały uzyskać od władz tę część dotacji, jaka przypadała dla kasy parafialnej ${ }^{67}$.

Dla kapitałów, będących pod zarządem państwowym, przeznaczonych dla poszczególnych parafii (Abfindungskapitalien) odróżnić należy 2 podstawowe źródła płatnicze.

- dominia, czyli państwowe majątki ziemskie i

- lasy.

W roku 1875 zatrzymano z lasów (Forstverwaltung) $287 \mathrm{mk}$ i w listach rentowych $(4 \%) 33075 \mathrm{mk}$. Większa ilość kapitalów ulokowana była w majątkach ziemskich (Domainenverwaltung). Tutaj w gotówce było: $259 \mathrm{mk}$ i w listach rentowych $(4 \%) 101700 \mathrm{mk}^{68}$. Dochody z tych kapitałów przed ustawą kwietniową wypłacano 24 parafiom ${ }^{69}$. Nie

62 Tamże. Rozp. min. wyznań z dn. 28 XI 1875.

63 Wkrótce przeniesiony do Kościana.

${ }^{64}$ WAPB, j. w., Pismo nacz. prez. $z$ dn. 14 XII $1875 \mathrm{r}$.

65 Tamże. Pismo nacz. prez. z dn. 29 IV $1876 \mathrm{r}$.

${ }^{66}$ Prasa wymienia w r. 1883 następujących księży: ks. Moerke w Powidzu, ks. Kolany w Murzynnie, ks. Lizak w Pieraniu. Ten ostatni przebywał wówczas już w Skrzetuszewie w archid. pozn. Zob. Przegląd Katolicki R. XXIII, s. 76 .

${ }_{67}$ APP, j. w., k. 115. Sprawa dotacji dla parafii w Strzelnie.

${ }^{68}$ Tamże, vol. III, k. 147-156.

69 Tamże. Były to parafie: Łubowo, Kruszwica, Bydgoszcz, Strzelno, Chlewiska, Gniewkowo, Niestronno, Gąsawa, Lubcz, Duszno, Stodoły, Wójcin, Rzadkwin, Parlin, Strzyżewo Kościelne, Kwieciszewo, Ostrowo, Kędzierzyn, Ryszewko, Gościeszyn, Szczepanowo, Ostrowite 
wszystkie świadczenia $\mathrm{z}$ tych dwóch tytułów były oddawane $\mathrm{w}$ gotówce, lub ulokowane, jako kapital z wykupionych ciężarów realnych. Szczególnie na lasach państwowych spoczywały liczne zobowiązania w naturze, jako roczne wymiary drewna dla parafii lub beneficjum, prawo korzystania $z$ pastwisk leśnych i inne. Przeciętną roczną wartość tych świadczeń można zobrazować choć kilkoma przykładami.

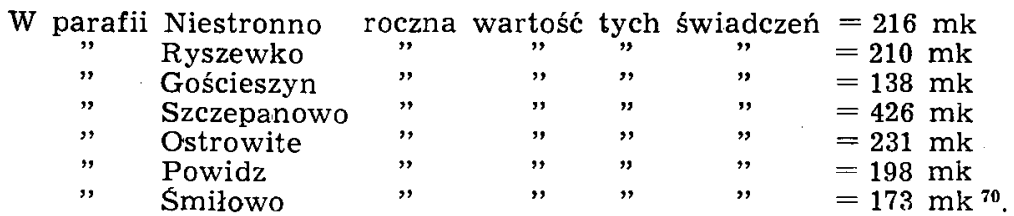

Są to wartości przeciętne. Renty realne $\mathrm{z}$ dominiów, czy lasów nie były bowiem każdego roku jednakowe. Niekiedy różnice między poszczególnymi latami wykazywały nawet dosyć znaczne wahanie ${ }^{71}$.

Sumując kapitaly pochodzące $z$ wykupu przez państwo ciężarów realnych na rzecz Kościoła nie można pominąć także drobniejszych kwot, powstałych z zaokrągleń większych kapitałów. W sumie odsetki od tych zaokrągleń wynosiły rocznie $202 \mathrm{mk}^{72}$. Kapitały natomiast, powstałe ze wspomnianego już wykupu ciężarów realnych dawały $\mathrm{w}$ sumie roczny dochód $\mathrm{w}$ wysokości ok. $5500 \mathrm{mk}^{73} \mathrm{Z}$ tego $\mathrm{w}$ czasie kulturkampfu państwo zatrzymywało rocznie $3808 \mathrm{mk}^{74}$.

Opierając się na zestawieniach sporządzonych przez władze rejencyjne bydgoskie w roku 1885 otrzyma się następujący obraz strat jakie duchowieństwo archidiecezji gnieźnieńskiej w rejencji bydgoskiej ponosiło w skali rocznej na skutek „ustawy obrocznej":

$-z$ rodz. 116 , tyt. 1 etatu

- $\mathrm{z}$ funduszu poklasztornego koronowskiego

$15371 \mathrm{mk}$ $420 \mathrm{mk}$

- z czynszów od kapitałów abluicyjnych

- z funduszu na polepszenie sytuacji materialnej duchowieństwa parafialnego razem: $20597 \mathrm{mk}$.

Pr., Powidz, Smiłowo. Poza tym dwie parafie należące do rejencji poznańskiej.

70 Tamże, k. 143-144.

71 Tamże, k. 145-147 i k. 14-21. Renta zbożowa jednego z folwarków dla parafii Eubowo wynosila: w r. $1876-279 \mathrm{mk}$ i $96 \mathrm{f}$. w r. 1877 -.. $344 \mathrm{mk}$ i $62 \mathrm{f}$.

72 Tamże. Pozycje A i B. w r. $1881-304 \mathrm{mk}$.

73 Tamże, vol. II, k. 169-197 i vol. III, k. 21.

74 Tamże, k. 185 i 291. 
W ciągu jedenastu lat zatrzymano więc łącznie $226565 \mathrm{mk}^{75}$. Suma ta zresztą była faktycznie nieco większa, jeśli doliczy się dotacje zatrzymane w 3 dekanatach leżących w rejencji poznańskiej. Część tych świadczeń zawarta jest wprawdzie w przytoczonym obrazie cyfrowym. Reszty jednak nie można obliczyć z taką dokładnością, jak to mialo miejsce $w$ przypadku rejencji bydgoskiej.

Gdyby przeprowadzić porównanie całokształtu zobowiązań materialnych państwa $w$ stosunku do duchowieństwa archidiecezji gnieźnienskiej $\mathrm{z}$ przeciętnym dochodem beneficjów, można by dojść do wniosku, że ustawa kwietniowa nieznacznie tylko zmniejszyła dochody proboszczowskie. Wniosek taki byłby tylko w częśi prawdziwy, nie można go bowiem odnieść do parafii uboższych oraz tych, których beneficjum bazowało glównie na dotacji państwowej. Poza tym jednak niesposób oddać trafnie sytuacji materialnej kleru w czasie kulturkampfu, jeśli nie powie się kilka słów na temat systemu kar administracyjnych i sądowych, przeważnie pieniężnych, stosowanego w czasie całego kulturkampfu z najwyższą surowością. Tutaj ponosiło duchowieństwo chyba najdotkliwsze straty.

Dla zrozumienia funkcjonowania wspomnianego już systemu kar, należy poświęcić nieco uwagi podstawom, na których kary te się opierały. Należy tu wymienić na pierwszym miejscu ustawy kościelno-polityczne 1873 r. Pierwsza z nich ukazała się 5 IV 1873 r. Zmieniała ona treść art. 15 i 18 konstytucji Królestwa Pruskiego, pozwalając na ingerencję państwa $w$ sprawy wewnętrzne Kościoła. W ten sposób ustawa ta stała się punktem wyjścia dla ustawodastwa majowego $1873 \mathrm{r}^{76}$. Pierwszą w tej serii ustawodawstwa była ustawa z $11 \mathrm{~V} 1873 \mathrm{r}$. dotycząca wykształcenia i zatrudnienia duchowieństwa ${ }^{77}$. Trzy następne dni przyniosły kolejne ustawy: o władzy dyscyplinarnej Kościoła i o utworzeniu Królewskiego Trybunału dla Spraw Duchownych ${ }^{78}$, o ograniczeniu w używaniu kościelnych środków karnych i poprawczych ${ }^{79}$, i o wystąpieniu z Kościoła ${ }^{80}$. Ustawy te, co tutaj należy

75 Tamże, vol. III, k. 291. Prócz funduszów z rozdz. 127, tyt. 3, reszta przekazywana była na tzw. konto zbiorowe (Sammelkonto).

76 GSS $1873 \mathrm{nr} 8112$. Gesetz betr. die Abänderung der Artikel 15 und 18 der Verfassungs- Urkunde. Vom 31 X 1850. Vom 5 IV 1873. Zob. też P. Hinschius, Die Preusschischen Kirchengesetze des Jahres 1873 , s. XXXIV-XXXV.

77 GSS 1875, s. 191 nn.

78 GSS 1873, s. $198 \mathrm{nn}$. Gesetz über die kirchliche Disziplinargewalt und die Errichtung des Königlichen Gerichtshofes für kirchliche Angelegenheiten. Vom $12 \mathrm{~V} 1873$.

${ }_{79}$ GSS 1873, s. 205. Gesetz über die Grenzen des Rechtes zum Gebrauch kirchlicher Straf- und Zuchtmittel. Vom $13 \mathrm{~V} 1873$. 
specjalnie podkreślić, stworzyły dla duchowieństwa w Prusach zupełnie nową sytuację prawną. Praktycznie rzecz biorąc zmusiły one duchowieństwo do wejścia $w$ kolizję $z$ prawem państwowym. Kolizja ta była czymś nieuniknionym, warunki bowiem stawiane Kościołowi przez ustawodawstwo majowe były dla niego nie do przyjęcia. Zignorowanie przez duchowieństwo nowego ustawodawstwa musiało się siłą rzeczy natychmiast ujawnić w postępowaniu. Podkreślane w nowych ustawach sankcje kiarne czekające opornych każą przypuszczać, że Bismarck i jego pomocnicy przewidywali negatywne stanowisko kleru. Prawdopodobnie jednak nie spodziewano się, że walka przybierze tak wielkie rozmiary. Poza tym główne założenia ustawodawstwa majowego - podporządkowanie Kościoła państwu - były dla Bismarcka tak ważne, że nawet perspektywa ciężkich zmagań nie zmieniłaby linii jego polityki. Ostatecznie więc cel, jaki sobie kanclerz wytyczył usuwał zapewne sprzed jego oczu bardziej trzeźwy i realny obraz bezpośrednich, a dla niego w gruncie rzeczy niepożądanych skutków kulturkampfu, jakimi były represje wobec duchowieństwa ${ }^{81}$. Niezależnie zresztą od przewidywań ustawodawców, walka kulturna od pierwszych dni jej trwania, tzn. bezpośrednio po wydaniu ustaw majowych przekształciła się właśnie $w$ system represji $i$ to stało się charakterystyczne dla całego kulturkampfu.

Trudno dokładnie ustalić jakạs przeciętną miarę wysokości kar nakładanych na duchowieństwo. Normy podawane $w$ ustawach byly bardzo wysokie, ale na ogół ścissle się ich nie trzymano. Wyroki karne władz administracyjnych i sądów za te same ,przestẹpstwa” stosowały różne kary. Komisarz dla zarządu majątkiem archidiecezjalnym nie mógł zresztą jednorazowo nałożyć większej kary pieniężnej, niż $150 \mathrm{mk}^{82}$. Zarządzenie to wydano jednak dopiero w $1878 \mathrm{r}$., co więcej dopiero wówczas zezwolono w ogóle komisarzowi na stosowante kár administracyjnych, podczas gdy do tego czasu czynił on to bezprawnie.

$\mathrm{Na}$ przestrzeni całego kulturkampfu można jednak wskazać na pewne czynności duszpasterskie, za których spelnianie kary były mniej więcej jednakowe. Najwcześniej zaczęto stosować kary wobec tych księży, którzy objęli stanowiska kościelne wbrew ustawie z $11 \mathrm{~V} 1873 \mathrm{r}$. Od początku r. 1874 do polowy r. 187511 wikariuszy w ten sposób zaangażowanych zapłaciło łącznie 1029 talarów (3087 mk) kar. Prze-

80 GSS 1873, s. 207. Gesetz betr. den Austritt aus der Kirche. Vom $14 \mathrm{~V} 1873$.

81 G. Fr a n z, dz. c.; s. 333 .

82 GSS 1878 , s. 87 . Gesetz betr. die Befugnisse der Kommisarien für die bischöfliche Vermögensverwaltung in der erledigten Diözesen Zwangsmittel anzuwenden. Vom 13 II 1878. 
ciętnie za odprawienie jednej mszy św. lub inną funkcję duszpasterską przewidywano karę $\mathrm{w}$ wysokości $5 \mathrm{mk}$. W przypadku niewypłacalności u skazanego, zamieniano mu karę pieniężną na więzienie, licząc jeden dzień za jedną markę ${ }^{83}$. W trzech kwartałach 1875 r. księża archidiecezji gnieźnieńskiej zapłacili łącznie $12438 \mathrm{mk}$ kar ${ }^{84}$. Typowym przykładem postępowania sądów pruskich $w$ tych przypadkach jest proces neoprezbytera, ks. Powałowskiego z Eopienna. Sąd powiatowy w Wągrowcu skazal go 15 I $1874 \mathrm{r}$. na karę 50 talarów (150 mk) lub 10 dni więzienia za nieprawne wykonywanie 45 funkcji kapłańskich (42 msze św., 2 kazania, 1 chrzest). Prokurator stawił wniosek o karę 10 talarów kary za każdą czynność. Od wyroku sądu, który jednak, jak widać nie poszedł za wnioskiem prokuratora, ten ostatni wniósł apelację, żądając dla oskarżonego 450 tal. kary lub 4,5 miesięcy więzienia. Na nowej rozprawie $w$ Wągrowcu ks. Powałowski sądzony byl o dalsze 50 czynności duszpasterskich, dochodziło do tego 11 wygłoszonych kazań ${ }^{85}$. Wyrok wydany 10 III 1874 r. skazywal go na zapłacenie dalszych 100 tal. grzywny lub miesiąc więzienia. Ostatecznie w wyniku nowych wyroków kara na ks. Powałowskiego wzrosła do 7,5 miesiąca więzienia. Odbył on ją $w$ całości $w$ więzieniu trzemeszeńskim ${ }^{86}$. Podobnie ks. Drews z Nakła został za "nieprawne” czynności duszpasterskie najpierw eksmitowany $z$ zajmowanego na probostwie mieszkania, następnie przez sąd skazany 9 II 1874 r. na 100 tal. kary. W marcu tegoż roku otrzymał ks. Drews następny wyrok, skazujący go na 200 tal. lub 6 miesięcy więzienia. Epilogiem tego wszystkiego było aresztowanie ks. Drewsa 17 IV 1874 r. i osadzenie go na 9 miesięcy w lobżenickim więzieniu ${ }^{87}$.

Inna sprawa ,która stała się dla władz podstawą do wymierzania licznych kar, była sprawa tajnego delegata apostolskiego, a potem arcybiskupiego, działającego na terenie archidiecezji gnieźnieńskiej i poznańskiej. Od chwili aresztowania arcybiskupa działał w obu archidiecezjach delegat apostolski. Po wypuszczeniu arcybiskupa $z$ więzienia i udaniu się jego do Rzymu tajny rządca nosił nazwę tajnego delegata arcybiskupiego. Główne natężenie akcji rządowej przeciwko tajnemu delegatowi przypada na czas do maja 1874 r. ${ }^{88}$ Indagowani o osobę

8s Kur. Pozn. 1874, 25, 27, 41, 48, 208, 1875, 144, 164. Podawano tu dokładne wykazy ukaranych księży, zaznaczając również wysokość kary.

84 Kur. Pozn. 1874, 12.

85 Kur. Pozn. 1874, 41.

${ }^{86}$ Kur. Pozn. 1874, 208.

87 Kur. Pozn. 1874, 41, 64, 89.

88 Kur. Pozn. 1875, 111. 
i działalność tajnego delegata dziekani i kanonicy kapitulni byli karani za odmowę zeznań. Do marca $1875 \mathrm{r}$. w ten sposób ukarano 12 dziekanów i trzech wikariuszy gnieźnieńskich ${ }^{89}$. Metodę postępowania władz pruskich na tym odcinku można najlepiej prześledzić na przykładzie sprawy ks. Zbierskiego, dziekana ze Slesina. Nie mógł on przybyć do sądu $z$ powodu obłożnej choroby. Skutkiem tego czterokrotnie przyjeżdżała do niego delegacja sądowa z Bydgoszczy, by przeprowadzić przesłuchanie. Ks. Zbierski nie przyjmował jednak przedstawicieli sądu, prosząc o odłożenie sprawy, aż do chwili swego całkowitego wyzdrowienia. Mimo to sąd bydgoski skazal go zaocznie na zapłacenie $150 \mathrm{mk}$ kary oraz wyznaczył nową rozprawę na dzień 12 IV $1875 \mathrm{r}$., zastrzegając, że w przypadku nieobecności na niej wezwanego, kara podwyższona zostanie do $30,0 \mathrm{mk}$. Ponowna apelacja ks. Zbierskiego sprawiła, że sąd odroczył sprawę na pewien czas, pierwszej kary jednak nie cofnął. Nie uchylił też sankcji za niestawienie się $w$ sądzie ${ }^{90}$. W gruncie rzeczy ks. Zbierski postąpil słusznie, gdyż w maju $1875 \mathrm{r}$. prokurator bydgoski zrezygnowal całkowicie z przesłuchiwanie go.

Trzecim wreszcie rodzajem kar, najczęściej stosowanym, szczególnie wobec proboszczów, były kary za odmawianie korespondencji z komisarzem dla zarządu majątkiem arcybiskupim. Komisarz ten, szczególnie po ukazaniu się ustawy o zarządzie majątkiem $w$ gminach katolickich zaczął przybierać wobéc proboszczów coraz częściej postawę

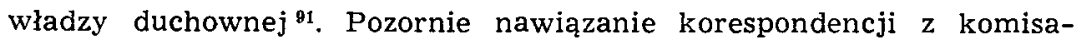
rzem można było uznać za zwyczajną styczność z administracyjną władzą państwową. Faktycznie jednak było inaczej. $\mathrm{Z}$ ustawy $\mathrm{z}$ dnia $20 \mathrm{~V} 1874 \mathrm{r}$. bynajmniej nie wynikało, że komisarz byl funkcjonariuszem administracyjnych władz państwowych. Był to raczej urząd powierniczy, sprawowany $\mathrm{z}$ polecenia wladz państwowych. Uzasadnienie takiego pojmowania stanowiska komisarza opiera się przede wszystkim na dwóch bezspornych faktach. Komisarz był, mianowicie, opłacany nie przez państwo, ale $\mathrm{z}$ funduszu uposażenia stolicy arcybiskupiej, ściślej z uposażenia osobistego arcybiskupa. Dalej, ustawa z $20 \mathrm{~V}$ 1874 r. wyraźnie przyznawała stosowanie środków przymusu wobec duchowieństwa naczelnemu prezesowi, a nie komisarzowi 92. Ustawa $z$ dnia 20 VI $1875 \mathrm{r}$. orzekała, że decyzje $w$ sprawie majątku parafialnego mogła podejmować władza biskupia po porozumieniu się

${ }^{89}$ Kur. Pozn. 1875, 51.

90 Kur. Pozn. 1875, 104.

${ }^{9}$ Spór, jaki na tym tle powstał szczególnie między dozorami a komisarzem należy do spraw związanych z ustawą z 20 VI $1875 \mathrm{r}$. Zob. s. 2.

${ }_{22}$ GSS 1874, s. 135 nn., $\S 6,9,10$.

14 - Prawo Kanoniczne 
z. naczelnym prezesem ${ }^{93}$. Jeżeli wladza biskupia była chwilowo w zawieszeniu, wówczas uprawnienia jej odnośnie majątku parafialnego przechodziły na władzę páństwową ${ }^{94}$. Zalążek przyszlego sporu o kompetencje komisarza tkwił więc $w$. sformułowaniach przytaczanych ustaw. Kto bowiem krył się faktycznie za enigmatycznym zwrotem, użytym w $\S 43$ ustawy z 20 VI 1875 r., gdzie mowa ogólnie o „władzy rządowej"? Scisła interpretacja tego określenia przez czynniki kościelne była dla rządu bardzo niewygodna, komisarz bowiem w swym postępowaniu dawał wyraźnie do zrozumienia, że i on zalicza się do władzy rządowej w rozumieniu cytowanego $\S 43$. Kres wszelkim wątpliwościom $w$ tej sprawie miał położyć wyrok Trybunału dla Spraw Duchownych, wydany 3 XI $1877 \mathrm{r}^{96}$ Wyrok ten omawiał prawa komisarzy po ustawie $\mathrm{z} 20 \mathrm{~V} 1874 \mathrm{r}$. Paragraf 9 tej ustawy, wedlug orzeczenia wyroku, miał przyznawać komisarzom prawo nie tylko w stosunku do majątku stolicy biskupiej, ale i do majątku diecezjalnego. Komisarz miał więc prawo żądać od rządców parafii pisemnych sprawozdań $z$ ich działalności $w$ zakresie administracji majątkiem parafialnym. Wyrok Trybunału miał niewątpliwie nakłonić opornych księży do wejścia w kontakt służbowy z komisarzem. To samo doty czyło dozorów parafialnych. Pozostawała jednak nadal wątpliwość, czy komisarz, na podstawie tego orzeczenia, miał prawo wymierzać księżom kary administracyjne. Ostatecznie przecież wyrok Trybunału przyznawał komisarzowi tylko taką władzę nad majątkiem parafialnym, jaką posiadał ordynariusz. Nie można wiẹc tutaj mówić o prawie do nakładania kar administracyjnych. Wątpliwości $w$ tej sprawie pochodziły, jak się okazuje nie tylko ze środowisk kościelnych, nawet bowiem sejm pruski wydal tu'w r. 1878 orzeczenie na niekorzyść komisarza ${ }^{97}$. Wspomniane orzeczenie Izby Deputowanych Landtagu mogło bardzo skomplikować polożenie prawne komisarza, dlatego też już w lutym 1878 r. rząd przeforsowal w sejmie nową ustawę, przyznającą komisarzowi prawo nakładania kar ${ }^{88}$. Ustawa ta, choć dla Kościoła bardzo niekorzystna, zlikwidowała jednak częściowo dwuznaczny charakter stanowiska komisarza. Ta dwuznaczność mogła zresztą dla samego komisarza mieć dosyć przykre konsekwencje, na ogół bowiem

93 GSS 1875, s. 241 nn., $§ 42$.

94 Tamże, § 43.

95 Tamże. W tekście niem. „Staatsbehörde".

96 Reichs- und Staats-Anzeiger 1877. Odpis wyroku sąowego Trybunału dla Spraw Duchownych z dn. 3 XI 1877.

${ }^{97}$ Stenographische Berichte über die Verhandlungen des Heuses der Abgeordneten Bd II 1878, s. 1351-1352. Anlege 156. Orzeczenie to wydane przy omawianiu sprawy komisarza dla diecezji monasterskiej. ${ }^{98}$ GSS. 1878 , s. 87. 
ukarani przez komisarza grzywną, po pierwszym orzeczeniu Landtagu dla komisarza niekorzystnym, wnosili skargi o zwrot wpłaconych tytưłem kar pieniędzy. Sądy byłyby zmuszone wyrokować na korzyść poszkodowanych, tak więc ustawa lutowa z 1878 r. była po prostu rodzajem wyjścia z impasu. Nie oznaczała ona jednak, co należy podikreślić, bynajmniej wszechmocy komisarzy. Już $w$ dwa tygodnie po jej wydaniu Falk zalecił naczelnym prezesom, by czuwali nad umiarkowanym stosowaniem przez komisarzy kar. Żądał też powiadomienia siebie o każdym przypadku wniesienia apelacji przez ukaranego ${ }^{99}$. Trzeba pamiętać, że był to rok 1878, powoli kończyła się już kariera Falka, a rozpoczynał się drugi etap kulturkampfu, charakteryzujący się stopniowym odwrotem rządu z zajmowanych, wobec Kościoła pozycji ${ }^{100}$.

Mogło by się wydawać, że spór o kompetencje kołnisarza został załatwiony. $Z$ jednej strony przyznano komisarzowi znaczne uprawnienia, $z$ drugiej starano się dopilnować, by ich nie nadużył. Faktycznie jednak sytuacja duchowieństwa $w$ ogóle nie uległa zmianie dzięki takiemu załatwieniu sprawy. Właściwie można śmiało mówić o jej pogorszeniu się, duchowien̉stwo bowiem, które nie zmieniło bynajmniej swego poglądu na sprawę komisarza, zostało teraz zmuszone do wyraźnego oporu wobec jeszcze jednej ustawy. Uznanie przez księży kompetencji komisarza, zarówno 'wynikającej z ustawy majowej 1874 r., jak i czerwcowej $1875 \mathrm{r}$. oraz ostatniej z $1878 \mathrm{r}$. byłoby pośrednim uznaniem istniejącego stanu rzeczy, co za tym idzie przyjęciem, jako faktu dokonanego zlożenia arcybiskupa ze stolic gnieźnieńskiej i poznańskiej. Tego władze niewątpliwie pragnęly, ale dla ogólu duchowieństwa była to rzecz niewykonalna. Trzeba przyznać, że komisarze, szczególnie Massenbach próbowali w dosyć przebiegły sposób zyskać dla siebie uznanie wśród księży. Wystarczało np., że ksiądz, proszący - umorzenie kar zaadresował swą prośbę: do komisarza królewskiego dla zarządu majątkiem arcybiskupim ${ }^{101}$. Komisarz zaręczal, że tego rodzaju wnioski będą rozpatrywane pozytywnie, nie taił jednak, że użycie przez petenta takiej tytulatury uważać będzie za pośrednie uznanie swych kompetencji. Zawód, jaki tu spotkał komisarza, kosztował księży niewątpliwie dużo pienłędzy, był on jednak zarazem znakiem, że obrana droga nie prowadzi do celu.

Perspektywa ewentualnej przegranej, sprawiała, zapewne, że kary za odmowę prowadzenia korespondencji z komisarzem były szczególnie dla duchowieństwa uciążliwe. Przy pierwszym ukaraniu grzywna

99 APP, j.w., D I 11, vol. Ir, k. 99.

100 G. Franz, dz. c., s. 223.

101 Kur. Pozn. 1876, 56. 
wynosiła $30 \mathrm{mk}$, przy drugim 50, przy trzecim 100. ${ }^{102}$ Sporadycznie spotykało się mniejsze kary np. 10 markowe, ale za to, przy częstym wówczas fantowaniu, poszkodowanie skazanego sięgało niekiedy kilkuset marek, chociaż sama kara była o wiele niższa. Tak np. zdarzylo się w przypadku ks. Gieburowskiego z Kamieńca. Pierwsza nałożona na niego kara byla jak na owe czasy, niska, wynosiła bowiem $10 \mathrm{mk}$. Ponieważ ks. Gieburowski tej kary nie zapłacił, wymierzono mu nastẹną w wysokości $20 \mathrm{mk}$, trzecia grzywna wynosiła już $50 \mathrm{mk}$, zagrożono też księdzu udaniem się do władz rejencyjnych w Bydgoszczy. IRejencja nakazała przeprowadzić na plebanii w Kamieńcu fantowanie, by wyegzekwować nałożone kary. Zajęto więc proboszczowi m.in. 4 z pięciu posiadanych przez niego sutann. Eącznie wartość zafantowanych rzeczy wynosiła $400 \mathrm{mk} .{ }^{103}$

Sankcje karne zapowiadane przez ustawodawstwo pruskie nie byly więc czczymi pogróżkami. Stosowano je z całą. bezwzględnością. Jeśli zważy się, że każdy niemal proboszcz musiał w jakiś sposób zająć stanowisko wobec komisarza i każdy ponosił konsekwencje swego negatywnego ustosunkowania się do tego urzędnika, latwo sobie wyobrazić, jak trudna musiała być wówczas sytuacja finansowa ogółu duchowieństwa. W czasie całego kulturkampfu obsadzenie osieroconych parafii było zupełnie niemożliwe. Liczba ich stale wzrastała. Np. w r. 1880 lączna liczba osieroconych parafii $w$ archidiecezji gnieźnieńskiej wynosiła $49 \mathrm{z}$ łączną ilością wiernych 62 721. ${ }^{104}$ Trzeba przyznać, że rawet za cenę największych ofiar, starali się księża spełniać posługi duszpasterskie w tych parafiach. Kary za poszczególne czynności duszpasterskie uznane przez władze za nieprawne stopniowo wzrastały do 20 a nawet nieraz $50 \mathrm{mk}$, za każdą funkcję ${ }^{105}$. Od kar tych nie były wolne nawet takie posługi, jak zaniesienie pociechy religijnej chorym i umierającym ${ }^{106}$. Karalna była nawet pomoc sąsiedzka $z$ racji odpustu, czy innej uroczystości ${ }^{107}$.

Obecność policji na każdym odpuście, a często nawet na zwykłych nabożeństwach pozwalała władzom administracyjnym dokładnie sledzić wykonywane przez księży funkcje duszpasterskie ${ }^{108}$. Praktycz-

102 Kur. Pozn. 1875, 149.

103 Kur. Pozn. 1875, 263.

104 Kur. Pozn. 1880, 300 (dane statystyczne). Liczba dusz sprawdzona według Elenchu archidiecezji gnieźnieńskiej, $1874 \mathrm{r}$.

${ }_{105}$ Kur. Pozn. 1876, 227. Zob. też Pastoral-Blatt, Münster 1876, nr 9, s. 2-4.

${ }_{106}$ Kur. Pozn. 1877, 233 i 1880, 17, 37.

107 Kur. Pozn. 1875, 227 i 247.

108 Kur. Pozn. 1875, 145. Przedrukowano tu zarządzenle radcy ziemiańskiego pow. wągrowieckiego Posadowsky'ego, nakazujące policji kontrolowanie każdego odpustu. 
nie więc, pomijając księży działających tajnie, żadne inne „przestępstwo" duszpasterskie nie uchodziło bezkarnie.

Tak wielka ilość nakładanych kar, chociaż często przez księży nie płaconych, musiała jednak $w$ końcu wyczerpać możliwości płatnicze duchowieństwa. Ten wzgląd, jak i wspomniane wyżej nieplacenie kar spowodowały nasilanie się akcji fantowania. Przykładowo wspomniano już o takich przypadkach, warto powiedzieć coś o metodach tutaj powszechnie stosowanych. Przede wszystkim egzekutorzy w stosunku do księży nie krępowali się zbytnio ustawami chroniącymi własność dłużnika ${ }^{109}$, chociaż ustawy takie istnialy $i$ co więcej drobiazgowo ustalały, jakie przedmioty nie mogły ulec rekwizycji. Nieliczenie się z. przepisami doprowadzało do fantowania takich rzeczy, jak sutanny, płaszcze, futra, zegarki $i$ inne przedmioty codziennego użytku ${ }^{110}$. Wyprowadzano $z$ gospodarstw proboszczowskich na licytację bydło, konie, pojazdy gospodarskie. Obkładano aresztem dochody z dzierżaw probostw, niekiedy nawet na kilka lat wprzód ${ }^{111}$. O przesadzie, jakiej dopuszczali się urzędnicy pruscy w czasie fantowania niech świadczy przypadek ks. Koehlera $\mathrm{z}$ Sokolnik ${ }^{112}$. Ksiądz ten miał w sumei do zapłacenia $880 \mathrm{mk}$ kary. W wykazie jednostkowych kar, wchodzących w skład tej sumy, dwie pozycje odnotowane byly jako zapłacone. były to kwoty $48 \mathrm{mk}$ i 80 fenigów oraz $180 \mathrm{mk}$. Pierwsza suma pochodziła ze sprzedaży licytacyjnej 500 szefli ziemniaków (1 szefel = $40 \mathrm{~kg}$ ). Niskość uzyskanej za te ziemniaki ceny tłumaczy się tym, że obłożone aresztem, a nie zabezpieczone przed mrozem, nadmarzły. Ks. Koehler udał się ze skargạ do naczelnego prezesa w Poznaniu, domagając się, by policzono mu za ziemniaki normalną cenę $1 \mathrm{mk}$ 50 fenigów za 1 szefel. Naczelny prezes jednak odmówił rozpatrzenia tej skargi $w$ trybie administracyjnym i radził złożyć skargę do sądu. Kogo jednak miał skarżyć poszkodowany ksiądz, jeśli hierarchia zainteresowanych sprawą osób rozciągała się niemal na wszystkie szczeble terenowych władz administracyjnych? Skuteczność skargi, jak się zresztą okazało w kwestii spornej przy następnej sumie, była znikoma. Druga pozycja we wspomnianym wykazie kar, wynosząca $180 \mathrm{mk}$, po-

${ }^{109}$ GSS 1853 nr 3881. Verordnung, wegen exekutivischer Beitreibung der direkten und indirekten Steuern und anderer öffentlicher Abgeben und Gefälle, Kosten etc. in den ösltichen Provinzen, mit Auschliessung Neuvorpommerns. Vom 30 VII 1853. Nie podlegały zgodnie z tym rozporządzeniem fantowaniu: pościel, odziè, sprzęty domowe, rzeczy służby, inwentarz gospodarstwa domowego ( $\$ 12$ ).

${ }^{110}$ Kur. Pozn. 1875, 45, 266, 267 i 1876, 129.

111 Kur. Pozn. 1876, 129, 213. $1880,44$. 
chodziła $z$ licytacji, na której sprzedano 3 krowy, będące $w$ oborze plebańskiej, należące jednak zgodnie ze sporządzonym aktem notarialnym, do bratowej ks. Koehlera dr Wandy Koehler. W dniu 19 VI 1875 r. wniosła ona do sądu w Poznaniu skargę przeciwko komisarzowi, domagając się zwrotu zabranej sobie wlasności ${ }^{113}$. Sąd I instancji, wyrokiem z dnia 6 IX $1876 \mathrm{r}$. uznał winną stronę zaskarżoną, nakazując jej zarazem zapłacenie kosztów sądowych ${ }^{144}$. Sąd apelacyjny w Poznaniu, w wyniku skargi apelacyjnej komisarza Massenbacha orzekł w dniu 26 III (1877 r., że koszta sądowe powinny ponosić obie strony ${ }^{115}$. Podobny wyrok wydano $10 \mathrm{IX} 1877 \mathrm{r}$. Wreszcie wyrok III senatu Głównego Trybunału Królewskiego przysądził koszty ostatniej apelacji całkowicie p. Koehler. Sprawa więc przewlekała się przez z górą dwa lata i ostatecznie strona zaskarżająca w wyniku obarczona została jedynie dodatkowymi kosztami. Można tylko dodać, że opisana tu procedura sądów pruskich powtarza się nieustannie w czasie całego kulturkampfu ${ }^{116}$.

System kar w połączeniu z ustawą kwietniową 1875 r. musiały mocno osłabić pozycję ekonomiczną duchowieństwa. Niekiedy pozostawały proboszczowi tylko dochody $z$ akcydensów, jak wiadomo niewielkie. Pozostałe dochody tytułem kar obkładano aresztem, nie wahano się postępować $w$ ten sposób nawet $w$ odniesieniu do sum legatowych, nie mówiąc już o dziesięcinach. Trudności materialne proboszczów powodowały nawet ich zaleganie $w$ płaceniu cathedraticum. Już w r. 1875 zalegało tu 8 dekanatów, lącznie 41 parafii ${ }^{117}$. Sprawa ta zresztą była bardziej skomplikowana, niż by się mogło wydawać. Jak wiadomo, cathedraticum pochodziło $z$ opłat za akty metrykalne. Ponieważ jednak wszystkie parafie pozbawione proboszczów, nie posiadały wówczas ksiąg metrykalnych, zabranych przez landratów, nie mogły one tym samym wydawać aktów metrykalnych, więc i płacić cathedraticum ${ }^{118}$. Nie tu jednak leży jedyna przyczyna zaległości we wpłacaniu kapitule cathedraticum, zalegały bowiem również parafie posiadające proboszczów. W odpowiedzi na monity kapituły i dziekanów odpowiadali oni, że nie mogą wysyłać cathedraticum z powodu trudności finansowych ${ }^{119}$. Monity te powtarzają się aż do końca walki kulturnej, tłumaczenie proboszczów pozostało też nie zmienione ${ }^{120}$.

113 AAGn, j.w., k. 2-3. Zob. też APP, j. w., D I 16, vol. II, k. 162. 114 AAGn, j.w., k. 57.

115 Tamże, k. 126.

116 Kur. Pozn. 1878, 10, 121, 217. s. 7 .

117 Cathedraticum nie było placone $z$ dochodów probostwa. Zob.

118 AAGn, A. kap. S. 67 Gr II. Akta dot. par. Szczepanowo.

119 Tamże, Akta dot. par. Dębnica.

120 Tamże, Akta dot. parafii dekanatu żnińskiego. 
Niejednokrotnie racje przedstawiane przez proboszczów informuja nas zarazem, że w wielu przypadkach cały rnajątek proboszczowski obłożony był aresztem ${ }^{121}$. Zaleganie $w$ opłatach $\mathrm{z}$ tytułu cathedraticum było jednak dla księży niebezpieczne. Na podstawie bowiem ustawy $\cap$ nadzorze wladz nad majątkiem kościelnym $\mathrm{z}$ dnia 7 VII $1876 \mathrm{r}$. ${ }^{122}$ były corocznie przeprowadzane kontrole państwowe kasy kapitulnej. $Z$ łatwością więc dostrzegały władze niedobory $w$ cathedraticum, co powodowało oskarżenie księży o przywłaszczenie sobic cudzego mienia ${ }^{123}$.

Kapituła miała zresztą inne jeszcze dowody ubóstwa księży w czasie kulturkampfu. Jednym $z$ nich jest zapewne list, $w$ którym ks. Weidner z Solca prosil kapitułę w r. 1880 o wsparcie na zakup ziarna siewnego, gdyż, jak twierdził, $z$ powodu całkowitego zajęcia dochodów proboszczowskich przez władze, nie posiadał na to funduszy ${ }^{124}$.

Na uwagę zasługuje jeszcze szczególnie trudne położenie księży, wyświęconych po ustawach majowych 1873 r. Często bez stałego miejsca zamieszkania, tropieni przez policję za spełnianie funkcji kapłańskich, nieustannie zagrożeni aresztowaniem i banicja ${ }^{125}$, nie mieli oni do tego faktycznie żadnych stałych źródeł utrzymania ${ }^{126}$.

Wszystkim tym trudnościom towarzyszyła stale świadomość całkowitej bezbrơnności wobec władz państwowych. Przysłowiowa praworządność pruska i sprawiedliwość okazała się niestety w czasie kulturkampfu zwyczajnym mitem.

\section{Sprawa księdza Suszczyńskiego ${ }^{127}$.}

Postać ks. Suszczyńskiego nie zaslugiwałaby właściwie na wzmiankę, gdyby nie zupełnie wyjątkowe, nawet dla czasów kulturkampfu, postępowanie władz pruskich, z nią związane. Ks. Suszczyński byl proboszczem w Mogilnie, posiadał też godność kanonika honorowego kapituly poznańskiej. W dniu 1 IX $1875 \mathrm{r}$. ogłosil on $\mathrm{W}$ prasie poznańskiej, niemieckiej i polskiej oświadczenie, z którego wynikało,

121 AAGn, A. kap. S. 57 i 75 Gr 4 II, Akta dot. par. Zabartowo i Sośnica.

122 GSS 1876, s. $149, \S 1$.

123 AAGn, A. kap., S. 75 Gr 4 II. Dosłownie po niemiecku: „Unterschlag fremder Gelder".

124 AAGn, A. kap., O $30 \mathrm{Gr} 4$ II.

125 APP, Akta Polizeipräsidium Posen. III, 7015, A9.

126 AAGn, A. kons., A. N. 21/15, vol. 21. List ks. Andersza.

127 Sprawa ks. Suszczyńskiego przedstawiona jest na podstawie notatek prasowych Kur. Pozn., który korespondencję odnoszącą się do wspomnianego księdza podawał w dosłownych odpisach. 
że zerwał on z Kościołem katolickim i przystąpił do sekty starokatolickiej. Próbował nawet uzasadnić swą decyzję, podajac jako główny jej powód... negatywne ustosunkowanie się duchowieństwa katolickiego do nowego ustawodawstwa państwowego. Ks. Suszczyński widział $w$ tym jawne $i$ gorszące nadużycie. Prawdziwy powód jego decyzji tkwił jednak gdzie indziej. Jeszcze bowiem w r. 1875 ks. Suszczyński ożenił się i wyjechał do Królewca. Sprawa się jednak na tym nie skończyła. W pojęciu rządu bowiem, odstępstwo od Kościoła i opuszczenie zajmowanego urzędu nie było dostatecznym powodem, by pozbawić ks. Suszczyńskiego dochodów beneficjum mogileńskiego. Tak należy przynajmniej rozumieć nakaz wystosowany przez komisarza Nollaua do dozoru parafialnego $w$ Mogilnie, by dochody $z$ parafii byly nadal wypłacane ks. Suszczyńskiemu ${ }^{128}$. Stosownie do tego, w kilka dni później, zażądal eksproboszcz od dzierżawcy majątku proboszczowskiego w Babie, Hirschenbergera, wypłacanie należności dzierżawnej za czwarty kwartał 1875 r. Sprzeciwił się temu dozór parafialny, twierdząc, że według kontraktu dzierżawnego dochody z majątku należą się każdorazowemu proboszczowi rzymskokatolickiemu. Ks. Suszczyński już nim być przestał. Decyzję swą przesłał dozór komisarzowi Nollauowi, zaznaczając, że sprawy tej gotów jest dochodzić na drodze sądowej 129. Odpowiedź, jaką otrzymał dozór na początku r. 1876, była właściwie do przewidzenia, potwierdzała ona rzekome prawo ks. Suszczyńskiego do dochodów z beneficjuw' mogileńskiego ${ }^{130}$. Komisarz zaznaczył też, że pozwolenia na wniesienie skargi eksmisyjnej dozorowi nie udzieli ${ }^{131}$. Dozór oczywiście nie zadowolił się taką odpowiedzią i w 3 kolejnych pismach zwrócił się do naczelnego prezesa (27 XII 1875 i 8 oraz 24 I 1876), prosząc o odebranie dochodów beneficjalnych eksproboszczowi Suszczyńskiemu. Naczelny prezes odpowiedział dozorowi dopiero 17 VI 1876 r. Odrzucił żądanie dozoru, tłumacząc się tym, że wobec prawa państwowego ks. Suszczyński nadal uprawniony jest do pobierania dochodów z probostwa mogileńskiego, gdyż kara dyscyplinarna kościelna za odstępstwo i za zawarcie małżeństwa mogła by być nałożona tylko przez władzę duchowną

128 Kur. Pozn. 1875, 223.

129 Kur. Pozn. 1875, 226.

130 Kur. Pozn. 1876, 19.

131 Nollau postępował tu według ustawy z 20 VI 1875 r., $\S 51$ (GSS 1875 , s. 241 nn.). Stosownie do tego paragrafu dozór potrzebował do wstąpienia na drogę sądową pozwolenia państwowej władzy nadzorczej. Art. 1 pkt 3 rozporzadzenia wykonawczego $z$ dn. 27 IX $1875 \mathrm{r}$. (GSS 1875 , s. 571) stwierdzal jednak, że władzą taką jest prezes rejencji, a więc groźba Nollaua nie miała uzasadnienia. 
archidiecezji gnieźnieńskiej, tej jednak aktualnie brakuje ${ }^{132}$. Innymi słowy, naczelny prezes domagał się wytoczenia ks. Suszczyńskiemu procesu kanonicznego. Praktycznie było to niemożliwe, gdyż konsystorz nie mógł spełniać swych funkcji, a arcybiskup pozbawiony był przez państwo urzędu. Zresztą nawet gdyby wyrok na ks. Suszczyńskiego mógł być zgodnie z prawami kulturkampfu wydany, ostatnie slowo przysługiwało tu Trybunałowi do Spraw Duchownych w Berlinie ${ }^{133}$. Dla podkreślenia, że władze nie przyjęły do wiadomości rezygnacji ks. Suszczyńskiego z zajmowanego stanowiska kościelnego, przesłał mu naczelny prezes 24 VIII 1876 r., pismo dotyczące sprawowanego przez ks. Suszczyńskiego urzędu dziekańskiego. Ten jednak pisma nie przyjął, dając tym jeszcze jeden dowód, tym razem bezpośrednio władzom państwowym, że funkcji swych nie ma zamiaru nadal wypełniać ${ }^{134}$.

Stolica Apostolska zajęła wobec ks. Suszczyńskiego stanowisko już w r. 1875, doręczając mu za pośrednictwem członka dozoru parafialnego w Mogilnie Stanisława Różańskiego, pismo Sekretarza Stanu Jaccobiniego $\mathrm{z}$ dnia 31 XII 1875, wyznaczające odstępcy 60 dniowy termin na zerwanie zawartego małżeństwa i powrót do Kościola. Pismo to poza tym pozbawiało ks. Suszczyńskiego wszystkich piastowanych przezeń urzędów i godności, kościelnych oraz związanych $\mathrm{z}$ nimi dochodów. Państwo uznało ten krok Stolicy Apostolskiej, jako czyn wykraczający przeciwko art. 1 ustawy z $12 \mathrm{~V} 1873 \mathrm{r}$. Artykuł ten zabranial stosować na terenie Królestwa Pruskiego kar dyscyplinarnych kościelnych osobom nie mającym obywatelstwa pruskiego ${ }^{135}$. Innymi slowy, władze uznały ten czyn za przestępstwo, a Stanisławowi Różańskiemu za współudział $\mathrm{w}$ nim sąd trzemeszeński wymierzył karę 3 miesięcy więzienia ${ }^{136}$.

Drugie upomnienie dla ks. Suszczyńskiego nadeszło z Rzymu w maju $1876 \mathrm{r}$. Wreszcie 2 III 1877 r. Stolica Apostolska ekskomunikowała go i zdegradowała do stanu laickiego ${ }^{137}$. Losów majątku proboszczowskiego $\mathrm{w}$ Mogilnie jednak to nie zmieniło, gdyż na zarządzenie zastępcy komisarza dla archidiecezji gnieźnieńskiej, Perkuna 9 X 1876 r. ks. Suszczyński przybył z Królewca do Mogilna, by zgodnie $z$ ustawą czerwcową 1875 r., przekazać mająatek beneficjalny i pa-

192 Kur. Pozn. 1875, 149. Zob. też A. L. R., Th. II, Tit. 11, $\$ 778$ oraz $\S \S 318,319,320$.

13. GSS 1873, s. $198, \S \S 10,11$.

134 Kur. Pozn. 1876, 214.

135 GSS 1873, s. 198, art. 1.

136 Kur. Pozn. 1876, 169.

137 Kur. Pozn. 1877, 240. 
rafialny pod zarząd dozoru. W kilkanaście dni później ukazał się nowy dekret Perkuna, mianujący zarządcą majątku parafialnego w Mogilnie bezpośrednio ks. Suszczyńskiego, dozorowi zaś wyznaczający tylko rolę pomocniczą ${ }^{138}$. Ponieważ protesty dozoru nie odnosiły w dalszym ciągu pozytywnego skutku, pozostawało mu jedynie całkowicie odsunąc się od spraw związanych $\mathrm{z}$ zarządem majątkiem beneficjalnym.

Sprawa ks. Suszczyńskiego rzuca dużo światła na właściwe intencje Prus w stosunku do Kościola w czasach kulturkampfu. Nie przebierano w środkach, by zmusić duchowieństwo do uległości. Bezprawne postępowanie władz $w$ sprawie ks. Suszczyńslkiego miało zapewne zachęcić bardziej lękliwych i chwiejnych księży do wstępowania w jego ślady. Tego rodzaju naśladowców zabrakło jeđnak całkowicie.

Co szczególnie uderza $w$ sprawie ks. Suszczyńskiego, to bezduszna formalistyka, typowa dla władz pruskich, tutaj malssymalnie wykorzystana na niekorzyść Kościoła. Ta właśnie formalistyka, choć w innym wydaniu towarzyszyła każdej akcji wymierzanej przeciwko duchowieństwu.

Za k ończenie

Ustawy, o których mowa w niniejszym artykule, mają $w$ stosunku do calego kulturkampfu raczej charakter marginesowy. Nie można jednak zanegować ich wielkiego znaczenia $w$ dziedzinie wykonania ogółu ustaw kościelno-politycznych owego okresu, wydanych w Prusach.

Ustawa z $20 \mathrm{~V} 1874 \mathrm{r}$. miała zrealizować główny postulat ustawy z 11 V 1873 r. - mianowicie - oddać rządowi decydujący wplyw na obsadzanie stolic biskupich. Osiągnęła ona jednak swój cel tylko częściowo, doprowadzając do utworzenia tymczasowego, spornego w swych kompetencjach urzędu królewskiego komisarza do zarządu majątkiem arcybiskupim (w przypadku archidiec. gnieźn. i pozn.). Okazało się jednak w praktyce, że właśnie ten urząd, mając możność daleko idącego rozszerzania swych prerogatyw, stał się czynnikiem szczególnie uciążliwym dla duchowieństwa i dozorów parafialnych. Z inicjatywy komisarzy doszło $\mathrm{m}$.in. do tak olbrzymiego, a nawet przesadnego rozrostu systemu karnego.

Druga ustawa $\mathrm{z}$ dnia 22 IV $1875 \mathrm{r}$. miała za zadanie spowodowanie nacisku ekonomicznego na duchowieństwo. Zasadniczo też tylko w tym kierunku poszło jej wykonanie, przy czym państwo, dysponu-

138 Kur. Pozn. 1876, 248. 
jąc wstrzymanymi duchowieństwu funduszami, posługiwało się nimi dla kupowania sobie tych spośród księży, którzy wybrali wygodny i dostatni byt, kosztem powinności wobec Kościoła. Jako środek represyjny, ustawa kwietniowa osiągnęła właściwie nikłe wyniki. OIbrzymia większość zubożalego duchowieństwa nie zmieniła bowiem swej postawy wobec nowego ustawodawstwa. Poddało się kilku, tzw. księży rządowych, ale $i$ na to ustawa kwietniowa $w$ nikłym tylko stopniu wpłynęla.

Wyniki ustawy z $20 \mathrm{~V} 1874$ r., z punktu widzenia efektywnego, były niewątpliwie znaczniejsze, ale trzeba zarazem zaznaczyć, że właściwy cel ustawy - ustanowienie rządcy diecezji w zależności od władzy państwowej nie został osiagnnięty. Ostatecznie musiały władze wybrać drugą ewentualność, przewidzianą $w$ ustawie, nosząca jednak wyraźnie charakter półśrodka, tzn. wyznaczyć zarząd komisoryczny nad majątkiem archidiecezjalnym.

To podsumowanie wyników obu ustaw jest $w$ pewnym sensie uproszczeniem, o tyle jednak koniecznym, o ile fragment walki kulturnej od tej ujęty strony może okazać się pomocny jako punkt wyjścia do naszkicowania całości. Nic też dziwnego, że przeważają tu kwestie materialne, gdyż ustawy represyjne największy nacisk kładły właśnie na sprawy ekonomiczne.

Jeden wniosek nasuwa się nieodparcie. Przekonuje on o blędnej ocenie przez Prusaków duchowieństwa w ogóle, a w szczególności polskiego. Trudno też nie zauważyć swoistej taktyki władz pruskich; obok formalizmu biurokratycznego dostrzega się $w$ niej tendencje do obostrzenia surowych już z natury przepisów prawnych. Główny ciężar wykonania ustaw spoczął na barkach władz policyjnych. To ostatnie tylko $w$ części jest wyrazem najchętniej przez Prusaków stosowanej metody bezwzględnej egzekucji wymogów ustawowych, bardziej może na taki właśnie sposób walki wpłynął nieubłagany opór, jakiego władze wykonawcze doświadczały ze strony duchowieństwa.

\section{ZUSAMMENFASUNG}

Die Ausführung der Gesetze des Preussischen Landtags vom $20 \quad \mathrm{~V} 1874$ und 22 IV 1875 in der Erzdiözese Gnesen

Die im Mai 1873 durch den Preussischen Landiag herausgegebene kirchen-politische Gesetze, besonders das Gesetz vom 11 V 1873 über die Vorbildung und Anstellung der katholischen Geistlichen sind, von Anfang an, auf den Widerstand von Seite der kirchlichen Obrichkeit un der Geistlichen getroffen. 
Schon im Jahre 1874. wenn eine Reihe von Bischofsstuhlen in Preussen, und unter anderen auch der von Gnesen und Posen, unbesetzt gewesen war, musste der Staat daran denken, um wennauch eine vorläufige Diözesanverwaltung zustande bringen. Aus diesem Grunde ist das Gesetz über die Verwaltung erledigter kath. Bistümer vom 20. V 1874 ausgewachsen.

Die Domkapitel in Gnesen und Posen haben doch, dem Gesetze zuwider, den Generalwikar nicht gewählt, um damit mittelbar die staatliche Absetzung des Erzbischofs von Gnesen unci Posen Ledóchowski nicht bestättigen. In Folge dessen haben die Provinzialbehörden von Posen eine kommissarische Verwaltung des Vermögens der beiden Erzdiözesen eingesetzt. Für die Erzdiözese Gnesen wurde im Jahre 1874 der gnesener Landrat Nollau zum Kommissar ernannt. Ihm folgte im Jahre 1876 Massenbach, der die beiden Erzdiözesen verwaltete. Von 1877 bis zum Abschluss des Kulturkampfes war die kommissarische Verwaltung der beiden Erzdiözesen durch den ehemaligen Saatsanwalt zu Gnesen, Perkun, ausgeübt.

Die königlichen Kommissare deren Kompetenzen nicht klar gesetzlich bestimmt gewesen sind, der Absicht der Regierung jedoch gemäss, haben sich gern und nicht Erfolgslos, in die Verwaltungsangelegenheiten des Vermögens der katholischen Kirchengemeiden eingemischt. Dagegen die Geistlichen und die Kirchenvorstände weigerten sich mit den Kommissaren in Amtsverbindung einzutreten. Dafür war aber die ganze Geistlichkeit durch schwere Geldstrafen und oft auch durch Gefängniss und Ausweisung verfolgt.

Das ablehnende Verhalten der Geistlichen den staatlichen Gesetzen gegenüber hat den Autrieb gegeben $\mathrm{zu}$ einem neuen Gesetze, das am 22 IV 1875 erschien. Das war das berühmte „Brotkorbgesetz”, offiziell, als Gesetz betreffend die Einstellung der Leistungen aus den Staatsmitteln für die römisch-katholischen Bistümer und Geistlichen, bekannt.

Die unmittelbare Folge des Gesetzes war allerdings die Verärmung der Gestlichen. Es wurde auch die Tätigkeit einer grossen Zahl von kirchlichen Institutionen unmöglich geworden. Wenn man noch die Folgen des Strafsystems dazugibt, da kann man nich die Lage der Geistlichen, als eine leichte bezeichnen.

Trotzdem aber zur Zeit des ganzen Kulturkampfes waren in der Erzdiözese Gnesen sammt nur drei Parochien mit den sog. Staatspfarrern besetz. Diese Geistlichen hatten sich den Staatsgesetzen untergeordnet, aber sie wurden durch den, aus Pom wirkenden Erzbischof Ledóchowski mi dter Bann belegt und von den Gläubigen ständig boykottiert gewesen.

Die, durch die Gesetze vom 20 V 1874 und 22 IV 1875 herbeigeführten Verhältnisse, dauerten bis zum Jahre 1886. Erst dann wurde der gnesener und posener Erzbischofsstuhl wiederbesetzt und die Mehrzahl von den Kulturkampfsgesetzen aufgehoben. 